\title{
REDES SOCIAIS EM PROJETOS DE RECUPERAÇÃO DE ÁREAS DEGRADADAS NO ESTADO DE SÃO PAULO
}

\author{
LIVIAM ELIZABETH CORDEIRO BEDUSCHI
}

Dissertação apresentada à Escola Superior de Agricultura "Luiz de Queiroz", Universidade de São Paulo, para obtenção do título de Mestre em Ecologia de Agroecossistemas.

PIRACICABA

Estado de São Paulo - Brasil

Novembro-2003 


\title{
REDES SOCIAIS EM PROJETOS DE RECUPERAÇÃO DE ÁREAS DEGRADADAS NO ESTADO DE SÃO PAULO
}

\section{LIVIAM ELIZABETH CORDEIRO BEDUSCHI}

Eng enheiro Florestal

Orientador: Prof. Dr. DALCIO CARON

\begin{abstract}
Dissertação apresentada à Escola Superior de Agricultura "Luiz de Queiroz", Universidade de São Paulo, para obtenção do título de Mestre em Ecologia de Agroecossistemas.
\end{abstract}

PIRACICABA

Estado de São Paulo - Brasil

Novembro-2003 


\section{Dados Internacionais de Catalogação na Publicação (CIP)}

DIVISÃO DE BIBLIOTECA E DOCUMENTAÇÃO - ESALQ/USP

\section{Beduschi, Liviam Elizabeth Cordeiro}

Redes sociais em projetos de recuperação de áreas degradadas no Estado de São Paulo / Liviam Elizabeth Cordeiro Beduschi. - - Piracicaba, 2003.

145 p. : il.

Dissertação (mestrado) - - Escola Superior de Agricultura Luiz de Queiroz, 2003.

Bibliografia.

1. Ecologia humana 2. Ecologia florestal 3. Degradação ambiental 4. Legislação ambiental 5. Mata Atlântica 6. Meio ambiente - Recuperação I. Título

CDD 333.7153

"Permitida a cópia total ou parcial deste documento, desde que citada a fonte - $\mathrm{O}$ autor" 
Dedico esse trabalho ao meu companheiro Luiz Carlos Beduschi Filho, por me fazer acreditar em nossos sonhos. 


\section{AGRADECIMENTOS}

Com muita alegria agradeço ao Comitê de Orientação que me orientou desde o início da pesquisa, composto por:

Prof. Dr. Dalcio Caron, caríssimo mestre e amigo, que orienta meus caminhos desde a passagem pelo Pontal do Paranapanema.

Prof. Dr. Ricardo Ribeiro Rodrigues pela acolhida no LERF - ESALQ/USP e por iluminar os dias difíceis da pesquisa.

Prof $^{a}$. Dra . Lúcia da Costa Ferreira que muito admiro pela competência e alegria. ...Sem dúvida, este trabalho tem um pouco de cada um de vocês.

Agradeço a CAPES e EMBRAPA SNT- Escritório de Negócios de Campinas pelo auxílio financeiro da pesquisa.

Agradeço também à minha avó Angelina de Jesus Cordeiro, mulher forte com quem pude aprender tantas coisas e ouvir tantas histórias de vida.

Ao meu marido e eterno namorado, Luiz Carlos Beduschi Filho, com quem realizo meus sonhos!!

Ao meu querido pai Valter Luiz Cordeiro por depositar em mim grande confiança, amizade e carinho e àDalva pela alegria e amizade.

À minha mãe Milvia Elizabeth Franco por me ensinar que sempre existe um jeitinho especial de resolver as coisas com amor e, aos meus irmãos Normando, luri e lcaro que buscam rumos novos para a vida.

À minha grande família: tias, tios, primas e primos... pela alegria de encontrá-los sempre festejando a vida!

A querida família Beduschi: Lúcia e Luiz Carlos, Vó Aninha, Daniel e Fran, Aninha e Fred. Pelo amor e carinho de uma família muito especial. 
À minha grande amiga-irmã Paty Sant'Anna com quem pude aprender sobre buscas e conquistas... Especialmente àfamília Sant'Anna e Helder.

Agradeço a Deus pela oportunidade de conhecer pessoas especiais, que viveram comigo descobertas e grandes experiências: Mariana Wongtschowski, Ilan Kruglianskas, Karen Suassuna, Valquiria Garrote, Rosana Maia, Carolina Marques, Adriana Ricci, Viviane Risseto, leda e Cinara Sanches, Patricia Medice, Laury Cullen Jr., Fabiano Mazzilli, Giba, Mou e Má, Haroldo, Ana Paula Cruz, Flavio Quental. Valeu moçada, sem vocês não teria tido graça!!

Aos queridos amigos Marcos Malagodi e Gisele, pela amizade e por me acolherem tantas vezes com muito carinho em Campinas.

Á Cristina Velasquez, com muito carinho...agradeço as melhores reflexões filosóficas da vida em nossas viagens à Américas!!. Também ao queridos Rodrigo e Luiza.

Aos colegas da Embrapa SNT/Campinas, o meu muito obrigada pela força e por acreditar neste trabalho. Agradecimentos especiais à Vera Scholze Borges, Rose, Lurdes, Ciro Scaranari e Edison Bolson.

Não poderia deixar de agradecer à equipe do Projeto Matrizes de Árvores Nativas: Marta Muniz, Vicente Buffo, Alexandre (Farelo), Flaviana Maluf, Natalia Ivanauskas, André Nave, Prof. Sergius Gandolfi, Prof. Vinicius, Prof. Flavio Gandara. Aos estagiários: Ana Lucia, Maria Carolina da Silva, José Banhara e à todos os amigos e funcionários do LERF-ESALQ/USP.

É claro, agradecimentos especiais àquerida Adriana Rozza, que tem muito a ver com todas estas páginas.

À querida Claudia lannelli que, com doçura, recebeu nossa equipe e tornout se grande amiga.

Ao Renato Lorza, da Rede de Sementes Florestais Rio-SP, por abraçar os workshops e acreditar em nossa proposta.

Aos pesquisadores do Instituto de Botânica/SMA, pelo apoio científico.

A todos que contribuíram com a pesquisa e gentilmente responderam æ̀े minhas perguntas o meu muito obrigada! 


\section{SUMÁRIO}

Página

LISTA DE FIGURAS........................................................................ viii

LISTA DE QUADROS......................................................................... ix

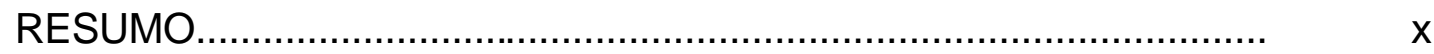

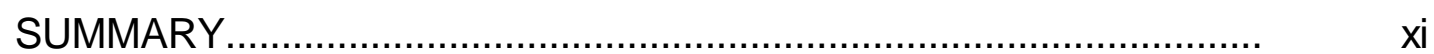

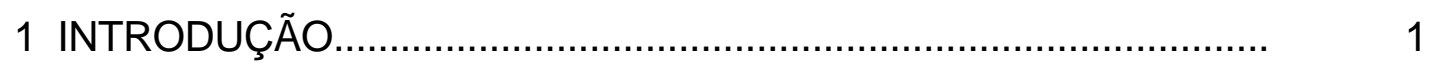

2 REVISÃO DE LITERATURA.....................................................

2.1 Mudança de paradigma na ecologia de restauração.................. 3

2.2 A contribuição da sociologia ambiental................................... 8

2.3 Causas sociais da degradação ambiental.............................. 11

2.4 Germinando a consciência ambiental....................................... 13

2.5 Redes socio-técnicas: tecendo fios entre a ciência e a política...................................................................... 16

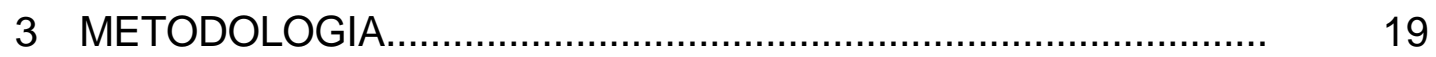

3.1 Objetivo ......................................................................... 19

3.2 Definição da hipótese.......................................................... 19

3.3 A pesquisa .................................................................... 20

3.4 Os atores sociais............................................................... 21

3.4.1 As fontes de pesquisa........................................................ 23

3.4.2 O diário de campo.................................................................. 24

3.5 O Projeto Matrizes de Árvores Nativas...................................... 24

3.5.1 As intervenções............................................................... 25

3.5.2 Organizando os workshops regionais .................................... 25

3.5.3 O formato dos workshops regionais ....................................... 27 
3.6 Localização da área de estudo............................................... 28

4 RESULTADOS ...................................................................... 30

4.1 Mapeamento dos atores sociais............................................ 30

$4.2 \quad$ Categorias dos ato res sociais............................................... 32

4.3 Resultado dos workshops regionais........................................ 35

4.3.1 Banco de dados de atores sociais em RAD........................... $\quad 35$

4.3.2 A RAD nas regiões ecológicas............................................... 39

4.3.2.1 A região centro.................................................................... 40

4.3.2.2 A regiões sudoeste e noroeste.............................................. 41

4.3.2.3 A região sudeste....................................................................... 43

4.3.2.4 As regiões litorâneas...............................................................

4.3.3 A produção de mudas florestais nativas.................................. $\quad 45$

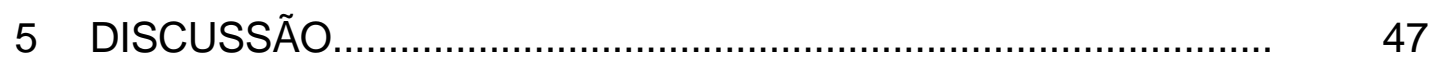

5.1 As arenas de disputa............................................................ 46

5.1.1 A arena da fiscalização ambiental........................................... 49

5.1.2 A arena da extensão florestal e produção de mudas................. 60

5.1.3 A arena da política de RAD.................................................... 71

5.1.2 A arena da ciência e pesquisa .............................................. $\quad 76$

5.2 Os desafios da rede social em RAD ......................................... 79

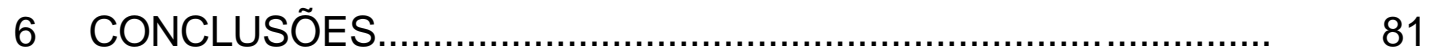

6.1 Conclusões sobre o Programa de Capacitação do Projeto Matrizes............................................................................. 86

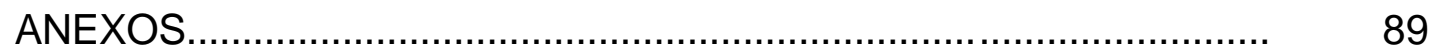

REFERÊNCIAS BIBLIOGRÁFICAS.................................................. 125

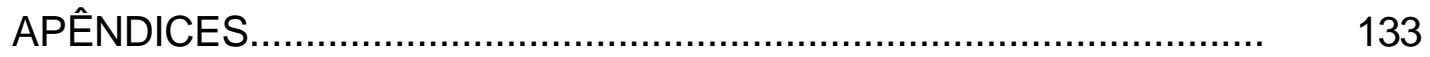




\section{LISTA DE FIGURAS}

Página

1 Divisão das regiões ecológicas do Estado de São Paulo.

2 Divisão regional do Departamento Estadual de Proteção dos Recursos Naturais/SMA.

3 Modelo do banco de dados de atores sociais por região e categoria social.

4 Perfil dos participantes do Workshop regional de Mogi Guaçu, SP...

5 Perfil dos participantes do Workshop regional de Chavantes, SP....

6 Perfil dos participantes do Workshop regional de Guarujá, SP

7 Distribuição dos viveiros de produção de mudas florestais de espécies nativas no Estado de São Paulo.

8 A rede social em projetos de RAD. 


\section{LISTA DE QUADRO}

Página

1 Categorias Sociais das instituições envolvidas em projetos de

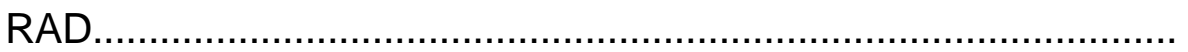

2 População e área dos principais municípios das regiões do Estado de São Paulo.

3 Reunião da Usina Cerradinho/Catanduva, SP.

58

4 Restrições legais para a colheita de sementes em áreas protegidas

69

5 A teoria assumida pela arena de pesquisa sobre RAD...

6 As arenas e as principais responsabilidades dos atores sociais....... 


\title{
REDES SOCIAIS EM PROJETOS DE RECUPERAÇÃO DE ÁREAS DEGRADADAS NO ESTADO DE SÃO PAULO
}

\author{
Autor: LIVIAM ELIZABETH CORDEIRO BEDUSCHI \\ Orientador: Prof. Dr. DALCIO CARON
}

\section{RESUMO}

O presente trabalho investiga a rede social composta por organizações envolvidas na problemática da recuperação florestal na Mata Atlântica no Estado de São Paulo (Brasil). A recuperação de áreas degradadas é um dos principais desafios para cientistas, poder público e todos os atores sociais que buscam reverter o processo de destruição das florestas naturais. Com o aprimoramento da legislação ambiental, a rede de atores sociais torna-se densa e os conflitos entre eles tornam-se mais explícitos em diferentes "arenas de disputa", que são espaços de negociação, de conflitos e de mobilização social. A pesquisa confirma a hipótese de que apenas a mudança de paradigma científico na Ecologia de Restauração não é suficiente para garantir a qualidade de projetos de recuperação de áreas degradadas, sendo necessários uma estrutura de incentivos que estimule o fluxo de informações da rede social, a organização do setor de sementes de espécies florestais nativas, o melhor uso dos recursos florestais das unidades de conservação e a permanente negociação entre os atores sociais envolvidos em projetos de recuperação de áreas degradadas. 


\title{
SOCIAL NETWORK IN PROJECT OF RECOVERING OF DEGRADED AREAS IN SÃO PAULO STATE
}

\author{
Author: LIVIAM ELIZABETH CORDEIRO BEDUSCHI \\ Adviser: Prof. Dr. DALCIO CARON
}

\section{SUMMARY}

The present work investigates the social network composed by organizations involved in the problematic inquiries on forest recovering of Rainforest in São Paulo State (Brasil). The recovering of degraded areas is one of the main challenges for the scientists, the public government, and all the social actors that look forward to reversing the destruction process of natural forests. As the environmental laws improve, the social network actors become dense and the conflicts among them become more and more explicit in different "arena of debate", which are spaces for negotiation, conflicts and social mobilization. The research confirms the hypothesis that only changes in the scientific paradigm on Restoration Ecology is not enough to assure the quality of projects on recovering of degraded areas. In order to do so, a structure with incentives that stimulates the flow of social network information, the organization on the native forest seeds section, the best use of forest resources on the conservation units and the steady negotiation among the social actors involved in projects on recovering the degraded areas is necessary. 


\section{INTRODUÇÃO}

O objetivo principal deste estudo foi analisar como novos conceitos científicos irão conduzir à formulação de novas leis, recomendações e normas técnicas que, por sua vez, vão influenciar diretamente a forma como estão sendo orientados os projetos de recuperação de áreas degradadas no Estado de São Paulo. A hipótese levantada é de que apenas a mudança de paradigmas não garantirá a qualidade dos projetos de recuperação de áreas degradadas. É necessário o estabelecimento de espaços que permitam trocas, acordos e parcerias entre os atores sociais na busca de resolução de problemas ambientais, assim como uma estrutura de incentivos que estimule 0 compromisso dos atores sociais com a recuperação de ecossistemas degradados.

Para proceder tal análise, a dissertação firmou suas bases teóricas na Ecologia de Restauração e na Sociologia Ambiental, investigando a rede social que compõe o cenário atual dos projetos de recuperação de áreas degradadas no Estado de São Paulo.

Inicialmente, foi realizada uma revisão da literatura, identificando a recuperação de áreas degradadas como um importante desafio para os atores sociais inseridos nas mais variadas esferas de ação que buscam reverter 0 quadro de degradação que caracteriza as regiões abrangidas pela Mata Atlântica, no Estado de São Paulo. Uma leitura sobre a sociologia ambiental, em especial sobre os movimentos ambientalistas que apontaram as causas sociais da degradação ambiental no início da década de 70 , foi necessária para direcionar o estudo para a importância das redes sociais na questão ambiental. 
A seguir, foram definidos e detalhados os procedimentos metodológicos adotados para a investigação de campo, destacando-se o levantamento e a sistematização de dados sobre os atores sociais em recuperação florestal.

No capítulo que trata dos resultados, foram sistematizados e analisados os dados referentes aos workshops regionais organizados no Projeto Matrizes de Árvores Nativas ${ }^{1}$. Uma categorização dos atores socais envolvidos com projetos de recuperação florestal foi um dos produtos que orientou a análise do mundo dos atores sociais em suas 'arenas de disputa'.

No capítulo referente à discussão, a legislação ambiental foi bastante discutida e uma revisão das novas exigências técnicas para projetos de recuperação de áreas degradadas, especialmente a Resolução SMA 21(de 2111-2001), orientou a análise de algumas experiências entre os atores socais na aplicação das leis e exigências legais.

Vale destacar, nessa introdução, o desafio de tentar aproximar as ciências sociais (em especial a Sociologia Ambiental) e as ciências naturais (em especial a Ecologia da Restauração) no estudo das questões ambientais, como é o caso da Recuperação de Áreas Degradadas.

\footnotetext{
${ }^{1}$ Projeto Matrizes de Árvores Nativas desenvolvido por pesquisadores do Laboratório de Ecologia e Restauração Florestal da ESALQ/USP com apoio do Fundo Nacional do Meio Ambiente/Ministério do Meio Ambiente. Detalhes podem ser observados no site: http://www.lerf.esalq.usp.br
} 


\section{REVISÃO DE LITERATURA}

\subsection{Mudança de paradigmas na Ecologia de Restauração}

O tema recuperação de áreas degradas tem sido objeto de numerosos estudos nas últimas décadas, adquirindo caráter de uma nova área de conhecimento que tem como definição os aspectos teóricos e práticos relacionados com a recuperação e o funcionamento da integridade ecológica de ecossistemas, dentro de uma abordagem holística, envolvendo inclusive os aspectos sociais e econômicos (Rodrigues \& Gandolfi, 1996).

O conjunto de ações e estratégias para a recuperação de florestas dependerá dos objetivos pretendidos, sendo possível a utilização de diferentes métodos. Nessa abordagem da recuperação, muitos são os termos sugeridos, assim como restauração e reabilitação, no entanto, a recuperação de fragmentos florestais degradados rão pode ser discutida sem que se tenha clareza sobre os fatos responsáveis pela degradação dessas áreas, que por sua vez, estão inseridos no contexto de uso e ocupação do solo (Rodrigues \& Gandolfi, 2000).

A pesquisa e atividades relacionadas à recuperação de áreas degradadas, apresentam-se em constante evolução e é denominada por alguns autores de Ecologia de Restauração.

Nos últimos 15 anos o acúmulo de conhecimento sobre os processos envolvidos na dinâmica de formações naturais (tanto preservadas, quanto em diferentes graus de degradação) tem conduzido a uma significativa mudança na orientação dos programas de recuperação, que deixam de ser mera aplicação de práticas agronômicas ou silviculturais de plantios de espécies perenes, 
objetivando apenas a re-introdução de espécies arbóreas numa dada área, para assumir a difícil tarefa de reconstrução dos processos ecológicos, portanto das complexas interações presentes no ecossistema, de forma a garantir a perpetuação e sustentabilidade da floresta ao longo do tempo (Rodrigues \& Gandolfi, 2000).

No I Congresso de Espécies Nativas, realizado em 1982, percebe-se a mudança do conceito de restauração, baseando-se não só na utilização de espécies arbóreas nativas, mas definindo classificações das espécies por grupos ecológicos. Os grupos ecológicos foram caracterizados devido as suas funções em relação à dinâmica da floresta e reúnem uma série de classificações por diversos autores que buscavam, desde então, interpretar a dinâmica das florestas através da sucessão secundária, com atenção æ̀s clareiras que apresentam um papel fundamental na renovação da floresta e na definição da composição florística local.

Em 1989 foi realizado o I Simpósio sobre Mata Ciliar, no qual a discussão sobre as bases dos reflorestamentos heterogêneos reforçavam o uso das espécies arbóreas nativas regionais e dos diferentes grupos ecológicos. No entanto, é neste mesmo momento que surge a preocupação com a produção de sementes florestais de espécies nativas, uma vez que a necessidade de atender aos reflorestamentos e projetos de recuperação florestal demandavam a diversidade florística das florestas tropicais.

Segundo Barbosa (2002b), os trabalhos de reflorestamento de trechos de matas ciliares iniciaram-se com modelos que incluíam espécies exóticas, principalmente por não se conhecer as estruturas das florestas nativas tropicais e pela indisponibilidade de sementes e mudas de espécies nativas. Este autor faz uma análise sobre as principais conclusões e recomendações do I Simpósio sobre Mata Ciliar, ocorrido em 1989, identificando as lacunas relacionadas a metodologias de recuperação florestal, decorrentes dos poucos trabalhos e pesquisas sobre o tema, naquela época. 
Entre as propostas apresentadas em tal evento, a microbacia hidrográfica era reconhecida como uma unidade de análise para a recomposição e, portanto, deveria ser considerada em todos os seus aspectos ecológicos (geológicos, pedológicos, climáticos, de uso e ocupação), já demonstrando a importância da utilização de espécies nativas da região (mesma microbacia) adaptadas às características do local.

Nesse contexto, o Instituto de Botânica e o Instituto Florestal da Secretaria de Meio Ambiente do Estado de São Paulo, a Faculdade de Ciências Agrárias e Veterinárias da UNESP, a Escola Superior de Agricultura "Luiz de Queiroz" e o Instituto de Biociências da Universidade de São Paulo, passam a reunir informações sobre matas ciliares, produzindo pesquisas com enfoque na tecnologia de sementes, biologia e ecologia das espécies florestais, modelos de revegetação, entre outros aspectos que no futuro conduziriam os projetos de recuperação de áreas degradadas no âmbito de programas estaduais e políticas públicas.

No II Congresso Nacional de Essências Nativas, realizado em 1992, foram publicados os resultados dos primeiros reflorestamentos relacionados à sucessão secundária. Segundo Kageyama \& Gandara (2000) a partir dos anos 90 foi observado um grande aumento das iniciativas de restauração de áreas degradadas, principalmente em áreas ciliares. Para esses autores, o aumento das iniciativas de reflorestamentos e recuperação deve-se basicamente a dois fatores: conscientização da sociedade e exigência legal.

Atualmente, a recuperação de áreas degradadas vem se consolidando como uma importante estratégia de adequação ambiental de propriedades agrícolas, de empresas mineradoras, pressionadas pela legislação ambiental, e de programas municipais, que buscam a melhoria da qualidade de vida da sociedade, buscando proteger e recuperar as margens de rios.

O que se tem constatado, no entanto, é que os projetos para restauração florestal não têm atendido aos requisitos mínimos necessários para o restabelecimento dos processos ecológicos nas áreas em recuperação, 
requisitos esses relacionados principalmente com a diversidade florística e genética das florestas implantadas (Barbosa, 2002a; Kageyama \& Gandara, 2000).

A restauração florestal, com utilização de elevada diversidade de espécies arbóreas regionais e com diversidade genética, depende da oferta de sementes e mudas (Piña-Rodrigues, 2003). Porém, a oferta do mercado ainda é baixa, por uma série de fatores, tais como: a) dificuldade de identificação das espécies arbóreas nos remanescentes florestais; b) dificuldades dos viveiristas em obter informações para otimizar a produção das espécies coletadas, beneficiadas e comercializadas; c) coleta de sementes que não garante a confiabilidade da procedência e da viabilidade do material genético empregado em projetos de restauração, e, d) coleta de sementes sem critérios mínimos para garantir a reprodução de populações naturais e regionais, como por exemplo, coleta em árvores isoladas (Rozza et al., 2003).

Para concluir, visto que o que está em jogo é não somente a implantação de mudas no campo, mas sim procedimentos que garantam a sustentabilidade da floresta implantada os processos ecológicos deverão ser restabelecidos através do uso da diversidade florística e genética com características adaptáveis aos regimes hidrográficos, geomorfológicos e vegetacionais. Esses argumentos demonstram, claramente, a evolução do pensamento e do conhecimento acumulado sobre a Ecologia de Restauração, colocando em evidência novos métodos e recomendações que buscam não somente alcançar uma floresta idealizada, mas sim o que vai permitir a sua perpetuação e sustentabilidade. Para muitos, isso se traduz em uma mudança de paradigma na Ecologia de Restauração, onde o clímax único idealizado da comunidade florestal deixa de ser o foco principal da restauração, passando a ser importante reconhecer o histórico das perturbações locais que poderão afetar diretamente na condução da composição da floresta em formação. 
Se, até então, as exigências legais e práticas de reflorestamentos eram conduzidas no sentido de um único clímax florestal como o principal objetivo, hoje, o que se verifica, é a necessidade de mudanças nas recomendações, e portanto, na forma como elas serão colocadas em prática por inúmeras organizações que atuam com projetos de recuperação florestal, nas diferentes esferas e com diferentes interesses.

Nesse contexto, buscourse, com esta pesquisa, analisar como novos conceitos científicos vão conduzir àformulação de novas leis, recomendações e normas técnicas, que por sua vez, vão influenciar diretamente a forma como estão sendo orientados os projetos de recuperação de áreas degradadas. Para isso é preciso entender como se dá a organização dos diferentes atores sociais representados por cientistas, políticos, extensionistas e produtores, e identificar as relações que se estabelecem entre eles a partir de suas diferentes visões de mundo e interesses.

Percebe-se que diferentes formas de organização são estabelecidas entre os atores sociais envolvidos com recuperação de áreas degradadas. $O$ campo da sociologia ambiental tem contribuído para analisar as organizações sociais modernas, buscando explicações para as mudanças ambientais. Partese, portanto, desse enfoque para analisar a rede de organizações envolvidas em projetos de recuperação de áreas degradadas. 


\subsection{A Contribuição da Sociologia Ambiental}

A Sociologia Ambiental parece percorrer caminhos paralelos aos acontecimentos que despertaram na sociedade questionamentos sobre os problemas ambientais. Um desafio surgiu para os sociólogos no momento em que os sistemas institucionais das ciências sociais pareciam finalmente montados e claramente definidos, refletidos em métodos de investigação, análise e criação de literatura considerável da Teoria Social Clássica. Até há pouco tempo, as ciências sociais impunham para a sociedade a importância única de investigar o progresso e a racionalidade humana influenciados, entre outros, pelo pensamento de Durkhein, Marx e Weber (Ferreira, 2001).

No entanto, as práticas dos cientistas sociais começariam a mudar após a II Guerra Mundial, quando outras formas de análise e investigação abriram espaços para outras disciplinas, alargando suas preocupações para além dos demais temas já tradicionalmente aceitos, redefinindo o objeto de análise e integrando as intenções políticas que surgiam em movimentos sociais, grupos de pressão e organizações revindicatórias, dentre outros.

Segundo Ferreira (2001) foi nesse contexto de redefinição do objeto, que se introduziu o debate sobre a dimensão ambiental no interior da sociologia como conseqüência e resposta à intensificação dos impactos socio-ambientais negativos decorridos da expansão econômica e à reação social diante das evidências de degradação.

Embora tenha se desenvolvido tardiamente, quando comparada a outras áreas do conhecimento de abordagem ambiental como a biologia, a ecologia, a economia e a geografia, nos Estados Unidos a sociologia ambiental vive um significativo momento de produção científica, influenciando as questões colocadas pela sociologia contemporânea e sendo também influenciada por esta (Ferreira, 2001). 
A pesquisa científica sobre as inter-relações entre sociedade e ambiente encontra-se em rápida evolução em todo o mundo e juntamente com esta evolução se percebe a contestação social frente à situação emergencial da degradação dos recursos naturais e do desenvolvimento industrial. Grande contribuição para a relevância da questão ambiental foi o ambientalismo no início da década de 60 , quando o movimento social chamou a atenção da sociedade e dos sociólogos, que naquele momento ainda não dispunham de arcabouço teórico para uma análise direcionada à relação da sociedade e natureza.

Para Buttel (2001), a essência da sociologia ambiental enquanto subdisciplina da sociologia foi fundada na esteira da mobilização do movimento ambiental moderno e afirma que a maioria dos sociólogos ambientais da primeira geração, e grande parte de seus seguidores, são pessoas com fortes compromissos a favor do meio ambiente. A sociologia ambiental demonstra ter contribuições de várias outras sociologias, como a sociologia rural, a sociologia do desenvolvimento, a sociologia urbana, a dos movimentos sociais e, de certa forma, não surge como uma nova disciplina, mas dentro de disciplinas já existentes (Ferreira, 2001).

A questão teórica-metodológica se concentra em saber como o meio ambiente e os problemas ambientais devem ser conceituados. Em torno desse debate conceitual, estão em desenvolvimento algumas tendências teóricas da sociologia ambiental no mundo e também no Brasil. Grande parte da contribuição teórica parece estar fortemente vinculada à 'mudança ambiental', ou seja, explicações sobre as ações da sociedade que levam æ̀s mudanças no meio ambiente, causando a degradação ambiental ou escassez dos recursos naturais (Buttel, 2001). 
No entanto, as ações humanas produzem mudanças no meio ambiente que podem ser destrutivas, mas também positivas ou neutras (Buttel, 2001). Mudanças que também influenciam a criação de leis e normas para padronizar a ação dos agentes sociais (Levi, 1991; Ferreira et al., 2001; Buttel, 2001). Por este motivo, a perspectiva da sociologia ambiental apresenta-se como multidimensional, uma vez que não se reduz apenas a explicações de como reconstruir a qualidade do meio ambiente num sentido apenas biofísico.

A ciência ambiental vem assinalando a gravidade dos problemas ambientais e reconhece a necessidade de ajustes e adaptações se quisermos evitar a crise ambiental. O reconhecimento das dimensões dessa crise ambiental eminente contribui para "mudanças de paradigmas" na sociedade em geral e também na sociologia (rumo à rejeição da visão de mundo ocidental dominante e a aceitação de um novo paradigma ecológico ou ambiental). Desse modo, a reforma e a melhora ambiental serão produzidas pela difusão do novo paradigma ambiental entre o grande público e serão catalisadas por mudanças de paradigmas comparáveis entre os cientistas sociais e naturais (Catton \& Dunlap, 1994).

Em meio ao desenvolvimento da sociologia ambiental, autores como Hannigan, Beck, Leff, Guiddens, Viola, Ferreira, entre outros, são importantes referências teóricas, embora com enfoques metodológicos diversificados (Ferreira, 2001).

Para conduzir este estudo, a sociologia ambiental auxiliou na análise da ação dos diferentes atores sociais diante dos desafios apontados pela Ecologia de Restauração frente a metodologias de recuperação de áreas degradadas. 


\subsection{Causas sociais da degradação ambiental}

Entre os principais fatores de degradação de ambientes terrestres estão os desmatamentos para fins de agricultura, a urbanização, as obras de engenharia para a construção de estradas e ferrovias ou represas, a mineração a céu aberto, a super exploração da vegetação, as atividades agrícolas, incluindo o uso excessivo de produtos químicos, o uso de máquinas inadequadas, a ausência de práticas conservacionistas do solo e as atividades industriais ou bioindustriais que causam a poluição do solo (Dias \& Griffith, 1998).

A conseqüente fragmentação das paisagens por essas atividades constitui-se num dos fatos mais marcantes da interferência ambiental causada pelo homem. Este processo teve início com a colonização do Brasil, sendo intensificado nesse último século (Barbosa \& Mantovani, 2000). A degradação pode ser definida como o processo de alteração negativa do ambiente, resultante principalmente de atividades humanas que podem causar desequilíbrio e destruição, parcial ou total, dos ecossistemas (Watanabe, 1997)

Segundo Norgaard (1997), a degradação ambiental está atrelada àperda global de diversidade biológica, existindo dois principais fenômenos causadores desta perda. Primeiro, os níveis populacionais forçaram a transformação de áreas até agora relativamente não perturbadas em terras usadas para a agricultura. Segundo, poluentes agrícolas e industriais aplicaram uma pressão seletiva nova e estreitamente uniforme sobre as espécies. $O$ crescimento da população e as mudanças tecnológicas têm um impacto múltiplo, em vez de simplesmente aditivo, sobre o ambiente e a diversidade biológica. 
Esse mesmo autor afirma que a mudança na organização social também tem contribuído para a degradação ambiental e perda da biodiversidade. $O$ mundo, antes da revolução industrial, pode ser visto como um mosaico de sistemas ecológicos e sociais em coevolução, ou seja, os componentes do sistema social, tais como conhecimento, mitos, tradições, organização social e tecnologias dos povos locais estavam em acordo com a capacidade de se adaptar e evoluir.

Dentro do mosaico coevolutivo, os limites de cada área não eram distintos ou fixos. Mitos, valores, ơganização social, tecnologias e espécies ultrapassaram as fronteiras das áreas do mosaico dentro das quais eles inicialmente coevoluíram, para se tornarem exóticos em outras áreas. Alguns estavam pré-adaptados e floresceram, alguns coevoluíram e alguns morreram. Mas, de alguma maneira, eles todos influenciaram a coevolução posterior das características do sistema em suas novas áreas. Através dessas combinações de dispersão, os padrões das espécies coevolutivas, os mitos, a organização e tecnologia permaneceram retalhados e em constante mudança (Norgaard, 1997). 


\subsection{Geminado a consciência ambiental}

A participação política da sociedade em relação à qualidade de vida e conservação de áreas protegidas é uma característica da história do ambientalismo. Segundo Eckersley (1995), existem diferentes tipos de posições políticas ambientalistas, que representam um corpo de idéias e uma nova força em busca do equilíbrio ambiental. Mas, mesmo nessas políticas "verdes", há diferentes debates que não se restringem à tradicional e familiar divisão esquerda e direita. A mais significante diferença interna dentro das teorias verdes é o caminho do antropocentrismo até o ecocentrismo.

A idéia da existência de limites ecológicos para o crescimento econômico que, por sua vez, não pode ser dominado pela ingenuidade tecnológica e pela falta de planejamento, não foi seriamente acolhida até que o debate sobre os "Limites para o Crescimento" veio à tona, na década de 70. O ativismo ambiental foi visto como uma faceta dos movimentos civis que se preocupavam com uma maior participação popular e democrática nas decisões societárias e, nesse caso, no uso da terra e dos recursos.

O ambientalismo no Brasil emergiu nos anos 70 e início dos anos 80. Para Viola (1991), durante a fase de sua fundação, o ambientalismo brasileiro apresentava uma definição estrita da problemática ambiental que o restringiu, basicamente, a combater a poluição e apoiar a preservação de ecossistemas naturais, caracterizando uma dinâmica de distanciamento de diversas entidades em relação ao tema da justiça social. Parte significativa das associações ambientalistas tinha preocupações especificamente com o ambiente, levando muito pouco em consideração as dimensões sócio-econômicas da crise ambiental. 
A partir da década de 80 o movimento ambientalista apresenta uma nova característica, quando surge a percepção de que o discurso ambiental não se encontrava efetivamente disseminado na sociedade brasileira. Esse período é caracterizado por iniciativas que buscavam aprimorar os instrumentos legais de gestão ambiental, pela escolha de parcela dos ambientalistas em enveredar pelo campo político institucional, pela crescente profissionalização das organizações ambientalistas e pela maior aproximidade das organizações sociais e produtivas (Viola, 1991).

Por outro lado, a literatura especializada em movimentos sociais caracterizava o ambientalismo como um novo movimento social na Europa Ocidental. Este conceito trouxe contradições, já que o que se entende por movimento social são as formas de mobilização coletiva capazes de reivindicar a sociedade e a vida política. No entanto, nem toda ação coletiva procura atender a demanda social que espera uma posição política para resolver tais questões em pauta. Nem por isso se pode desconsiderar a contribuição do movimento ambientalista, seja ele considerado ou não como um novo movimento social, esteja ele em crise com sua identidade (Hannigan, 1995; Ferreira, 1993; Offe, 1985). Para Ferreira (1999), o ambientalismo surpreendeu a todos, ou a si mesmo, quando começou a esboçar interesses mais amplos de se constituir como um ator que ultrapassava as classes médias para dialogar com outros segmentos sociais e, também, ultrapassou suas próprias idéias estabelecidas inicialmente na oposição genérica a uma sociedade predatória e imediatista, para esboçar algo que parecia se constituir como um novo projeto de sociedade. 
Viola (1991) aponta a perceptível passagem de práticas que podem ser definidas apenas como reativas para práticas proativas. $O$ movimento ambientalista, caracterizado principalmente pela atividade de denúncia e criação da consciência pública sobre os problemas de deterioração sócioambiental, passa para uma fase, recentemente, caracterizada pela ação multissetorial, pelo processo de institucionalização de projetos específicos de conservação ou restauração ambiental, aliando neste perfil a problemática da proteção ambiental com a do desenvolvimento econômico sustentável.

Segundo Jacobi (2002), o ambientalismo tem assumido uma crescente influência na formulação e implementação de políticas públicas e na promoção de estratégias para um novo estilo, sustentável, de administrar os recursos naturais e promover o desenvolvimento socioeconômico.

A partir da segunda metade da década de 80 , a temática ambiental assume um papel bem mais relevante no discurso dos diversos atores que compõem a sociedade brasileira. $\mathrm{O}$ ambientalismo se expande e penetra em outras áreas e dinâmicas organizacionais, estimulando o engajamento de grupos sócio-ambientais, científicos, movimentos sociais e empresariais, nos quais o discurso do desenvolvimento sustentado assume papel de preponderância (Jacobi, 2002).

Apesar de toda a inserção da questão ambiental no discurso dos diversos atores, Viola (1991) aterta para a distinção dos níveis de discurso, do comportamento individual e da política pública. Destaca que há uma grande maioria de grupos sociais favoráveis a uma relação equilibrada entre desenvolvimento e meio ambiente, e há duas reduzidas minorias nos extremos, uma priorizando o desenvolvimento, e a outra, o meio ambiente. 
A importância discursiva da questão ambiental traduz-se na formulação de uma legislação bastante avançada, como a recente Lei 9.985/2000 referente ao Sistema Nacional de Unidades de Conservação - SNUC ${ }^{2}$.

O que se tem atualmente é uma política entre o discurso e a legislação: por um lado, há uma política que tem contribuído para estabelecer sistemas de proteção ambiental; por outro lado, existe ainda um afrouxamento no cumprimento das leis, permitindo aos indivíduos e æ̀s empresas ignorar importante proporção da legislação ambiental (Viola, 1991).

\subsection{Redes socio-técnicas: tecendo fios entre a ciência e a política}

Para o século XXI, o ambientalismo parece ter uma complexa agenda. Um compromisso que busca atender, em níveis nacional e internacional, articulações que propiciem a formulação de acordos e objetivos para implementação de uma Agenda 21 e dos compromissos que surgem a partir da Rio-92. Por outro lado, existe a necessidade de ampliar a capacidade de atuação, através de redes, consórcios institucionais, parcerias e outras engenharias que ampliem seu reconhecimento na sociedade e estimulem o engajamento de novos atores na definição de uma agenda que acelere prioridades para a sustentabilidade como um novo paradigma de desenvolvimento (Jacobi, 2002).

\footnotetext{
2 A partir de 18 de julho de 2000 instituiu-se a Lei 9985, sancionada pelo VicePresidente da República, que "regulamenta o art.225, $\delta 1^{\circ}$, incisos I,II,III e VII da Constituição Federal, institui o Sistema Nacional de Unidades de Conservação da Natureza e dá outras providências", mais conhecida como "Lei do SNUC" (Reserva da Biosfera da Mata Atlântica, 2000).
} 
Diferentes formas de organizações coletivas são estabelecidas entre os atores sociais envolvidos com Recuperação de Áreas Degradadas. Nesta análise, todos os momentos em que se abriram espaços para discussão e debates, como os workshops e reuniões técnicas, foram considerados como um espaço de construção social em que se estabelecem parcerias, disputas, acordos e desacordos ao redor da questão das sementes de árvores nativas.

Os atores vão tecendo fios entre si, como sugerem vários autores da sociologia da ciência e tecnologia que utilizam o conceito de redes sóciotécnicas:

"Toda dificuldade de tornar-se cientista hoje está no fato de que será preciso gerir essas redes. Redes totalmente heterogêneas, as quais chamamos de "técnico-econômicas" ou sócio-tecnicas", que atravessam as fronteiras entre ciência e política e que têm a propriedade de serem altamente conflituais" (Latour, 1995).

Segundo Callon (1986), seguindo-se os atores é possível analisar como eles constróem seus mundos, na medida em que forjam vínculos com outros, colonizando seus mundos num processo do qual emergem diversas redes de relações sociais.

Para Jacobi (2002), a problemática das redes tem adquirido uma importância crescente e singular nas duas últimas décadas, quando se observa um crescimento numérico das organizações da sociedades civil e a crescente transnacionalização das iniciativas da sociedade. Além disso, verifica-se o envolvimento com a questão ambiental proativa, não somente das ONG's, mas de entidades do governo, como a formação de secretarias municipais de meio ambiente e outras formas de atuação governamental em parceria com organizações da sociedade civil públicas e privadas. 
Redes sociais, para autores como Prins (1999), Rey (1999) e Lopes (1996), consistem em indivíduos interconectados que são ligados por fluxos de informações. Esse compartilhamento de informação ao longo do tempo leva os indivíduos a convergir ou divergir uns dos outros em seu entendimento mútuo da realidade.

Guivant (1998) incorpora em seu trabalho dois conceitos: o de "mundo dos atores" e o de "arenas de disputa". O primeiro, já citado anteriormente, se remete àteoria das redes sócio-técnicas, formuladas em diversos trabalhos por Callon (1986), Latour (1995) e Law (1992), enquanto o segundo conceito tem sido utilizado por Ferreira (1999), Fuks (1997), e anteriormente por Habermas (1981). O conceito de "arenas de disputa" contribui para ancorar o mundo dos atores em locais específicos. Trata-se de espaços de negociação, de conflitos, de mobilização de atores, sem que exista uma importância pré-definida especificamente a uma delas (Guivant, 1998). 


\section{METODOLOGIA}

\subsection{Objetivos}

Analisar como novos conceitos científicos vão conduzir à formulação de novas leis, recomendações e normas técnicas, que vão influenciar diretamente a forma como estão sendo orientados os projetos de recuperação de áreas degradadas.

\subsection{Definição da hipótese}

O problema de pesquisa que orientou o trabalho pode ser definido através das seguintes perguntas: quais são as condições socioambientais que garantem a qualidade dos projetos de recuperação de áreas degradadas? Apenas a mudança do paradigma científico da Ecologia da Restauração é suficiente para que os projetos de recuperação de áreas degradadas tenham mais qualidade?

A hipótese a ser testada, então, é de que apenas a mudança de paradigmas não garantirá a qualidade dos projetos de recuperação de áreas degradadas. É necessário o estabelecimento de espaços que permitam trocas, acordos e parcerias entre os atores sociais na busca de resolução de problemas ambientais, assim como estruturas de incentivos que estimulem o compromisso dos atores sociais com a recuperação de ecossistemas degradados. Quanto maior for a capacidade de articulação entre os atores, melhores serão os resultados. 


\subsection{A pesquisa}

A dissertação é um estudo analítico e descritivo que busca subsidiar programas de capacitação e extensão florestal. Os fundamentos teóricos utilizados basearam-se principalmente na sociologia ambiental (Ferreira et al., 2001) e na sociologia do conhecimento (Latour, 2000), contando também com o "olhar antropológico" (Brandão 1985) que permitiu adaptações nos métodos de coleta de dados em diversos ambientes freqüentados.

Estes ambientes freqüentados, ao contrário daqueles privilegiados pelo pesquisador das ciências naturais, que sai a campo para coletar o material botânico ou referenciar suas trilhas na Mata Atlântica, foram reuniões técnicas, seminários e workshops, participação em projetos, visitas em estabelecimentos, dias em escritórios e laboratórios de universidades.

É importante ressaltar que foi necessário buscar na sociologia ambiental elementos analíticos capazes de explicar as situações de confronto, resistência e politização social entre os atores sociais participantes desta pesquisa. Essa linha da sociologia, segundo Ferreira (2003), assume uma posição significante no estudo dos conflitos sobre a natureza e as causas dos problemas ambientais relacionados com os diversos atores sociais.

Foram necessárias anotações sistemáticas nos diários de campo, buscando registrar fielmente as experiências vivenciadas através da observação participante, das entrevistas e questionários, das conversas com os atores, dos documentos analisados e dos depoimentos públicos realizados em eventos e reuniões freqüentadas.

Após conhecer a rede de atores sociais foi possível cruzar as informações, buscando compreender claramente as suas posições políticas, seus interesses, interpretações sobre a legislação ambiental, motivações e linhas de projetos. Este método denominado teórico-construtivista, recentemente vem sendo utilizado por autores como Ferreira (1993), Fuks (1997) e Guivant (1998), baseando-se principalmente em Hannigan (1995). 


\subsection{Os atores sociais}

Como atores sociais, no âmbito desse estudo, foram consideradas as organizações existentes no Estado de São Paulo, públicas ou privadas, que de alguma forma estão envolvidas com a questão da conservação e recuperação de áreas degradadas, apresentando preocupações com o gerenciamento de recursos e/ou com a reparação de danos ambientais de suas respectivas regiões. O conceito de atores sociais foi adaptado para esta pesquisa, baseando-se em Ferreira et al. (2001) e A ndrade et al. (2002).

Para a melhor compreensão do contexto em que se insere a recuperação de áreas degradadas, optourse por categorizar os diversos atores sociais participantes do cenário estudado através de entrevistas, observação sistemática e análise de documentos (projetos, legislação, publicações, material de divulgação). O objetivo deste exercício foi conhecer a rede social que compõe o cenário atual dos projetos de recuperação de áreas degradadas no Estado de São Paulo conduzidos por cientistas, poĺticos e uma diversidade de profissionais da especialização florestal.

O primeiro contato com os atores sociais foi realizado a partir do envio de cartas de apresentação do Projeto Matrizes de Árvores Nativas da ESALQ/USP, no qual este estudo se encontra inserido. Com as respostas das primeiras cartas (apenas cerca de 15\% responderam) percebeu-se a necessidade de buscar outras fontes de informações. Foi então que se recorreu aos bancos de dados pré-existentes de instituições públicas para reunir o maior número possível de endereços e contatos de entidades envolvidas com recuperação florestal. Foram consultados os bancos de dados da Fundação Florestal da Secretaria de Estado do Meio Ambiente - FF/SMA, Coordenadoria de Assistência Técnica Integral, órgão da Secretaria da Agricultura e Abastecimento do Estado de São Paulo -CATI, do Departamento Estadual de Proteção dos Recursos Naturais -DEPRN/SMA; além de pesquisa 
na internet, na Ecolista, organizado por Mater Natura (1996), e através de contatos diretos do Projeto Matrizes.

Foram encaminhadas cartas para os endereços de todas as instituições que poderiam estar envolvidas com projetos de recuperação de áreas degradas, em qualquer esfera de atuação, sendo pública ou privada. Após o envio de cartas, os atores sociais mapeados foram convidados às intervenções do Projeto Matrizes, considerados como público-alvo das reuniões e eventos organizados (ver ANEXO A e B).

$\mathrm{Na}$ sistematização do mapeamento de atores sociais, foram reunidas informações sobre como se organizavam diante dos projetos de recuperação florestal. Desta forma, concentraram-se esforços para a categorização dos atores sociais relacionados à questão da recuperação florestal. Para a categorização foram observadas as seguintes características:

1- os serviços oferecidos e/ou as responsabilidades institucionais (produtiva, fiscalizadora, científica, política);

2- $\quad$ a relação com outras instituições que compunham a rede de cooperação e parceria nos serviços e responsabilidades (posição punitiva, agregadora, geradora de informações, política e comercial);

3- as linhas de projetos e políticas que eram apoiadas (conservacionista, preservacionista, desenvolvimentista). 


\subsubsection{As fontes de pesquisa}

A coleta de informações sobre a rede social em projetos de recuperação de áreas degradadas foi realizada em dois momentos da pesquisa. O primeiro momento se deu através de visitas aos atores sociais que respondiam æ̀s cartas e se interessavam em receber a equipe do Projeto Matrizes. Eram realizadas reuniões, em que o ator social que recebia a visita era incumbido de convocar os representantes de instituições envolvidos com projetos ambientais e proprietários rurais de sua região. Um roteiro de perguntas era sempre elaborado para o contexto, buscando reunir as principais informações para auxiliar na categorização social.

O segundo momento de coleta de informações se deu durante a participação em eventos e organização de três workshops regionais, que foram, fundamentalmente, planejados para gerar dados direcionados ao presente estudo.

Foram realizadas entrevistas semi-estruturadas com todos os palestrantes convidados a apresentar seus projetos nos workshops regionais. Os palestrantes, por sua vez, indicavam outros atores para serem consultados e assim a rede de atores foi investigada ao longo da pesquisa (ver ANEXO C e D). Durante os workshops regionais foram gravadas fitas que foram posteriormente transcritas e analisadas. 


\subsubsection{O diário de campo}

O diário de campo foi um importante material de pesquisa, onde os detalhes observados eram registrados. Assim, foram registradas as reuniões da equipe do Projeto Matrizes no Laboratório de Ecologia e Restauração Florestal na ESALQ/USP e as conversas durante as viagens de volta das reuniões com a equipe da Secretaria de Estado do Meio Ambiente.

O diário de campo também registrou os 11 meses de trabalho no escritório de Transferência de Tecnologia de Campinas da EMBRAPA, onde ocorreram importantes negociações para a realização dos workshops regionais.

\subsection{O Projeto Matrizes de Árvores Nativas}

É importante registrar que esta pesquisa foi desenhada a partir do momento que o Fundo Nacional do Meio Ambiente, através do Ministério do Meio Ambiente, aprovou, no ano de 2001, o projeto denominado "Diversificação e regionalização da coleta de sementes de espécies arbóreas nativas no Estado de São Paulo", resumidamente conhecido como "Projeto Matrizes de Árvores Nativas" ou simplesmente "Projeto Matrizes", que seria desenvolvido por uma equipe de pesquisadores (pós-graduandos, graduandos, funcionários e professores) do Laboratório de Ecologia e Restauração Florestal - LERF, da Escola Superior de Agricultura "Luiz de Queiroz" da Universidade de São Paulo - ESALQ/USP.

Partiurse da oportunidade de participar do Projeto Matrizes como coordenadora do "Programa de Educação Ambiental e Capacitação" para ir além das atividades colocadas como metas, buscando a análise do que tal projeto significaria no contexto político e científico. Desta forma, um duplo desafio estava colocado para a pesquisadora, pois a investigação seria muitas vezes mesclada com as responsabilidades de trabalho dentro do Projeto Matrizes. 
Nesse sentido, optou-se por adotar a pesquisa participante como um método que, segundo Thiollent (1986, p.9), daria condições para a "descrição de situações concretas e para a intervenção ou a ação orientada em função da resolução de problemas efetivamente detectados nas coletividades consideradas". O que se pretendia, conforme já colocado, era realizar a descrição e análise como projeto de pesquisa científica de um projeto nãocientífico, ainda que este último fosse gerador de informações e orientador de intervenções em programas de políticas públicas.

\subsubsection{As intervenções}

As intervenções realizadas no Projeto Matrizes contaram com a participação efetiva da equipe do Instituto de Botânica/SMA ${ }^{3}$ e do Escritório de Transferência de Tecnologia de Campinas da Empresa Brasileira de Pesquisa Agropecuária - EMBRAPA, SNT/Campinas. As intervenções foram basicamente concentradas em 03 workshops regionais que serão melhor detalhadas a seguir.

\subsubsection{Organizando os workshops regionais}

Os workshops regionais sobre "Espécies florestais em projetos de recuperação de áreas degradadas“ foram as principais intervenções desta pesquisa e cujo objetivo era divulgar e multiplicar as informações geradas sobre metodologias de recuperação de áreas degradadas, reforçando a importância da organização da produção regionalizada de sementes e mudas florestais nativas para garantir a diversidade genética e florística de projetos restauração florestal.

\footnotetext{
${ }^{3}$ Projeto "Modelos de repovoamento vegetal para proteção de sistemas hídricos em áreas degradadas dos diversos biomas do Estado de São Paulo" da linha de Políticas Públicas da FAPESP, sob coordenação do Prof. Dr. Luiz Mauro Barbosa, Diretor Geral do IBt/SMA.
} 
O público-alvo foi constituído por profissionais que estivessem envolvidos em ações voltadas a projetos de recuperação de áreas degradadas nos diferentes ecossistemas presentes no Estado de São Paulo. As características e peculiaridades dos ecossistemas adotados como regiões ecológicas no Projeto Matrizes (Rozza et al., 2003) podem ser observadas na Figura 1, baseada na divisão regional realizada por Setzer (1966) detalhada no item 3.5 dessa dissertação.

Para a composição do quadro de palestrantes optou-se por contatar, em primeiro lugar os escritórios regionais do Departamento Estadual de Proteção dos Recursos Naturais da Secretaria de Estado do Meio Ambiente DEPRN/SMA, pois a divisão regional onde se encontravam as suas unidades eram semelhantes às regiões ecológicas adotadas pelo Projeto Matrizes (Figura 2).

A escolha dos municípios para sediar o workshop regional estava relacionado também com a estrutura, tanto logística quanto financeira, das instituições que iam sendo contatadas e aprovando a proposta do evento. $\mathrm{Na}$ proposta do workshop eram apresentados os objetivos, a justificativa, o formato sugerido do evento e o orçamento necessário para a sua realização. Essas informações apresentadas na proposta eram elaboradas com a equipe do Projeto Matrizes e com a equipe da EMBRAPA, que a partir do ano de 2002 passou a ser um dos parceiros do Projeto Matrizes, disponibilizando uma bolsa do Conselho Nacional de Desenvolvimento Tecnológico - CNPq para a condução do "Programa de capacitação e educação ambiental" do Projeto Matrizes (ver ANEXO E).

Portanto, três principais critérios foram adotados para escolha do local dos workshops regionais: 1 - abrangência de regiões ecológicas: cada uma das regiões ecológicas apresentadas na Figura 1 deveriam ser contempladas no programa. Dessa forma, cada workshop deveria identificar a rede de contatos regional, convidando as instituições que atuavam naquele ecossistema; 2 estrutura institucional: cada workshop deveria garantir a presença de 
instituições com responsabilidades variadas, porém voltadas a projetos de reflorestamentos e recuperação florestal. As instituições que mais se identificavam com o Projeto Matrizes auxiliaram na organização local, indicando palestrantes e mantendo e divulgando informações sobre o evento; 3 patrocínio e estrutura logística: cada workshop dependeria de um local e material para aproximadamente 100 pessoas. Para isso foi necessário buscar recursos financeiros, já que o Projeto Matrizes não previu recursos suficientes para tal atividade.

\subsubsection{O formato dos workshops regionais}

Optourse por realizar cada workshop regional com a duração de um dia devido àlimitação de recursos financeiros e também pelo conteúdo, que não se pretendeu esgotar, mas incentivar as negociações regionais. Os temas abordados foram organizados em dois períodos, manhã e tarde. Para possibilitar não somente a exposição de palestras, mas também a participação do público, foram previstos dois debates realizados no final de cada período.

No período da manhã, os palestrantes deveriam conduzir suas apresentações sobre o assunto: (1) adequação e fiscalização de projetos de $R A D$. Para este assunto eram convidados o técnico do DEPRN regional e um promotor de justiça do meio ambiente de atuação na região. Este primeiro período também contava com uma apresentação dos fundamentos da recuperação florestal e da ecologia de restauração pelo professor Ricardo Ribeiro Rodrigues, coordenador geral do Projeto Matrizes, que esteve presente em todos os eventos e compondo a equipe de organização do evento.

No período da tarde o assunto abordado era sobre a: (2) produção de sementes e mudas nativas destinadas aos projetos de $R A D-$ que contava com palestrantes com experiências locais no mercado de sementes e mudas e legislação pertinente, como a Resolução SMA 21, de 21/11/01. 


\subsection{Localização da área de estudo}

O Estado de São Paulo possui grande variedade de situações fisiográficas, e alguns dos principais ecossistemas brasileiros do domínio extraamazônico são encontrados em terras paulistas: a Floresta Estacional Semidecidual, Floresta Estacional Decidual, Floresta Estacional Semidecidual Ribeirinha (Mata ciliar), Floresta Paludosa (Mata de brejo), Floresta Estacional Semidecidual de Altitude, Floresta Ombrófila Densa de Encosta (Mata atlântica Stricto sensu), Mangue, vegetação de Restinga e também as diferentes fisionomias do Cerrado (Veloso et. al., 1992; São Paulo, 1993).

Para representar essa diversidade de situações o Projeto Matrizes adotou zoneamento semelhante ao proposto por Setzer (1966), dividindo o Estado de São Paulo em 06 (seis) regiões ecológicas, conforme pode ser visualizado na Figura 1.

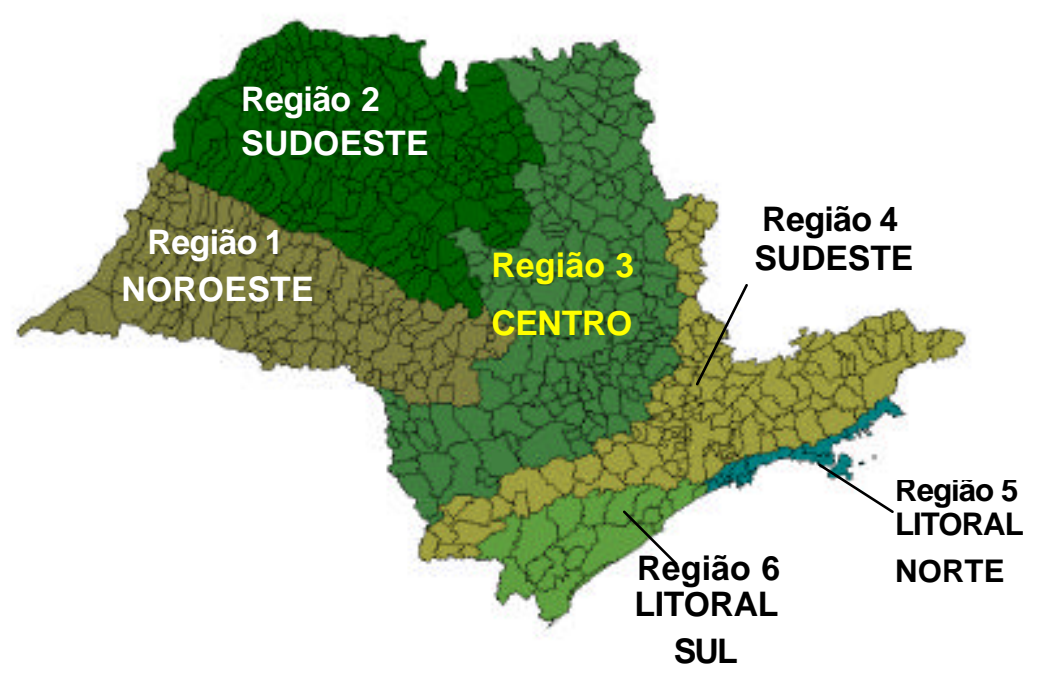

Figura 1 - Divisão das regiões ecológicas do Estado de São Paulo. 
As localidades dos workshops regionais foram baseadas tanto na divisões das regiões ecológicas adotadas pelo Projeto Matrizes, quanto nas regiões abrangidas pela Companhia de Tecnologia de Saneamento Ambiental CETESB e Departamento Estadual de Proteção dos Recursos Naturais DEPRN, ambos da Secretaria de Estado do Meio Ambiente - SMA (ver Figura 2). A intenção foi convidar instituições que seriam contempladas no mesmo raio de atuação do responsável técnico do DEPRN que seria convidado a palestrar no workshop regional. Desta forma, os palestrantes de cada evento eram indicados por outros palestrantes, tecendo uma rede de contatos e indicações. Assim também ocorreu com os patrocinadores, e demais participantes de cada região.

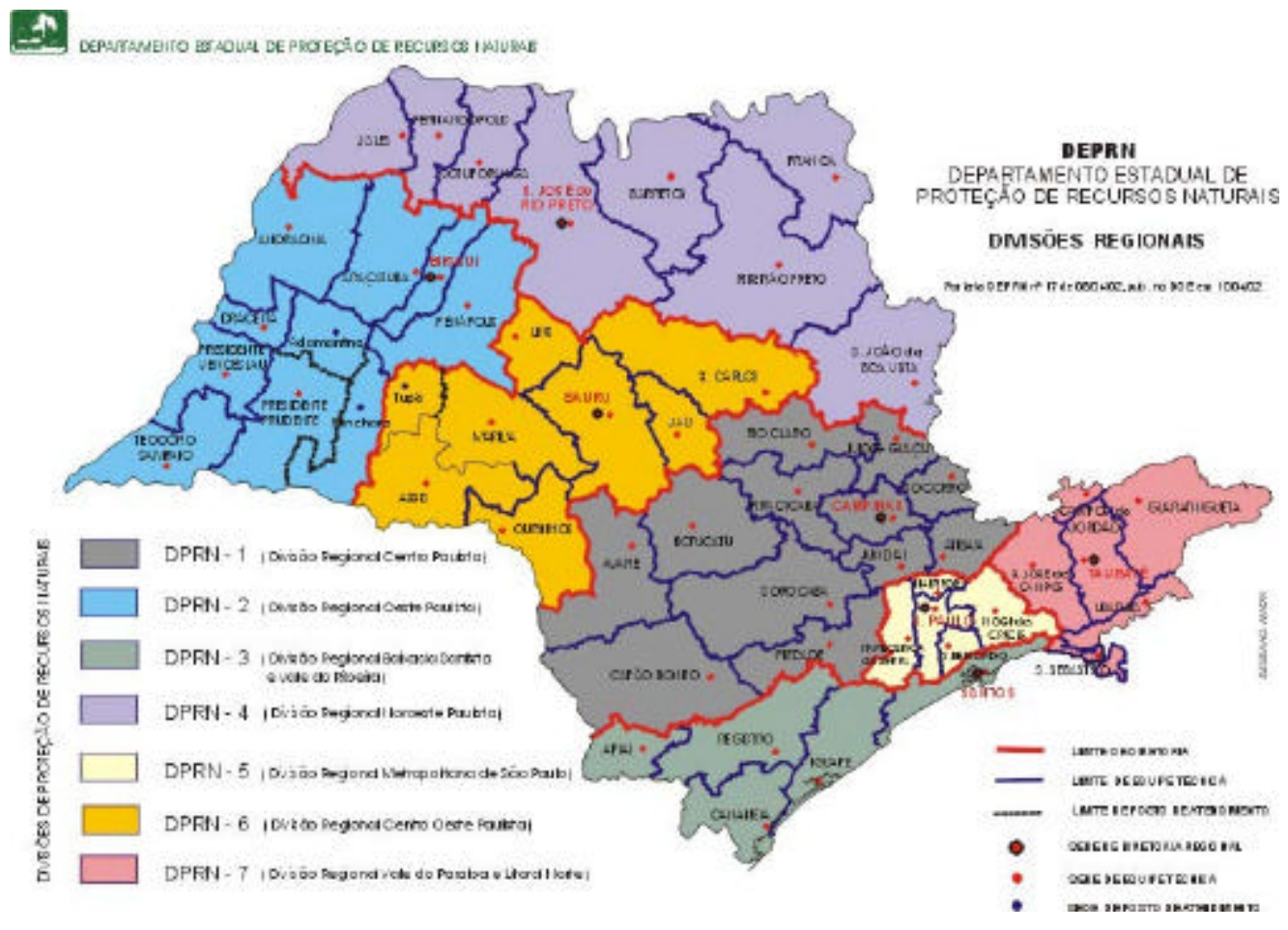

Figura 2 - Divisão regional do Departamento Estadual de Proteção dos Recursos Naturais - DEPRN/SMA.

Fonte: Companhia de Tecnologia de Saneamento Ambiental - CETESB (2003) 


\section{RESULTADOS}

\subsection{Mapeamento dos atores sociais}

Para conhecer quem são os atores sociais que constituem a rede social de projetos de recuperação de áreas degradadas no Estado de São Paulo, procurou-se detectar quais eram, como atuavam e em que regiões se concentravam.

O primeiro procedimento foi consultar os órgãos que poderiam disponibilizar relações e listas de contatos de instituições envolvidas em atividades de recuperação florestal. Esta consulta foi dirigida æ̀s unidades da Coordenadoria de Assistência Técnica Integral - CATI, órgão da Secretaria da Agricultura e Abastecimento do Estado de São Paulo que coordena o Programa Estadual de Microbacias Hidrográficas, e aos escritórios do DEPRN/SMA, que trabalham diretamente com o licenciamento ambiental. Desde então, se constatou a dificuldade de conseguir informações sistematizadas sobre instituições que atuam com recuperação florestal e foi necessário complementar a busca de informações a partir de outras fontes como: consultas em internet, listas telefônicas, Instituto Brasileiro de Geografia e Estatística - IBGE e mala direta do Instituto de Pesquisas e Estudos Florestais - IPEF. 
Ao encaminhar as cartas, que continham a apresentação do Projeto Matrizes e um convite para o cadastramento em um banco de dados, foram solicitadas informações como: endereço, número de telefone, endereço eletrônico, atividades desenvolvidas e, para aquelas que atuavam na produção de mudas e sementes era solicitado o envio da lista de espécies produzidas. De posse dessas informações, agrupourse, numa primeira versão, os atores sociais em diferentes categorias sociais, sendo: 1 - Viveiristas; 2 - DEPRN; 3 Unidade de Conservação; 4 - Proprietários rurais; 5 - Organização NãoGovernamental; 6 - CATI e 7 - Universidade.

Observando que alguns atores sociais atuavam em atividades complementares e/ou semelhantes, e que esta divisão poderia excluir muitos outros atores que no decorrer da pesquisa poderiam se cadastrar, a categorias sociais foram ordenadas de forma mais abrangente, mas não definitiva: 1 agentes de produção e extensão florestal; 2 - agentes de fiscalização; 3 agentes de pesquisa e; 4 - agentes de política ambiental.

Concomitantemente à fase de mapeamento de atores sociais em Projetos de recuperação de áreas degradadas, foram realizadas reuniões com os técnicos dos Núcleos de Produção de Mudas da CATI e do DEPRN/SMA, já que eram esses os órgãos que estavam mais diretamente relacionados, respectivamente, æ̀ ações de produção de mudas arbóreas nativas e proteção ambiental no Estado de São Paulo. De fato, esses órgãos auxiliaram no mapeamento de atores, indicando outros órgãos e instituições que poderiam ser contatados, complementando a pesquisa por região ecológica.

Em entrevistas e conversas informais realizadas junto aos viveiristas, técnicos, proprietários rurais e profissionais autônomos, foi possível conhecer as instituições parceiras das atividades de produção de mudas florestais nativas.

Os workshops regionais, organizados em três diferentes regiões, também contribuíram no mapeamento dos atores sociais, que reuniu um grande número de contatos institucionais a partir das fichas de inscrições (ver ANEXO F). 


\subsection{Categorias dos atores sociais}

Conforme descrito no item 3, foram encaminhados questionários para os palestrantes dos workshops regionais. Cruzando as informações dos questionários, depoimentos em público e as informações do banco de dados de atores sociais, organizourse o quadro de categorias sociais na tentativa de organizar e tipificar as principais características dos atores sociais quanto æ̀ responsabilidades e formas de atuação em suas regiões. No Quadro 1 estão apresentados os atores sociais em suas categorias $\mathrm{e}$ as principais responsabilidades identificadas através da pesquisa. Vale ressaltar que a categorização dos atores sociais foi uma forma de organizar os atores para auxiliar na análise das arenas de disputa. O método empregado foi adaptado de trabalhos realizados por Guivant (1998) e Ferreira et al. (2001) que detalharam as responsabilidades dos atores sociais no contexto dos conflitos institucionais. As categorias sociais desse estudo foram revisadas durante toda a sistematização do banco de dados de atores sociais e optou-se por reorganizar as categorias para uma versão oficial que também seria adotada pelo Projeto Matrizes. 


\begin{tabular}{|c|c|c|}
\hline $\begin{array}{l}\text { CATEGORIAS } \\
\text { SOCIAIS }\end{array}$ & RESPONSABILIDADES & ATORES SOCIAIS \\
\hline $\begin{array}{l}\text { 1. Produção de } \\
\text { sementes/ } \\
\text { mudas }\end{array}$ & $\begin{array}{l}\text { - Instituições que produzem mudas } \\
\text { e/ou sementes florestais nativas } \\
\text { para comercialização e/ou } \\
\text { pesquisa; } \\
\text { - Instituições que coletam, } \\
\text { beneficiam e comercializam } \\
\text { sementes florestais; } \\
\text { - Viveiros temporários para } \\
\text { atendimento de projetos } \\
\text { específicos (adequação, } \\
\text { ajustamento de conduta, } \\
\text { educação ambiental). }\end{array}$ & $\begin{array}{l}\text { - Associação de reposição } \\
\quad \text { florestal } \\
\text { - Viveiros de UC's } \\
\text { - Viveiros municipais } \\
\text { - Viveiros comerciais } \\
\text { - Associação de produtores de } \\
\text { sementes } \\
\text { - Rede de sementes } \\
\text { - Empresas de produção de } \\
\text { - sementes/mudas } \\
\text { - Associação de Produtores } \\
\text { Rurais }\end{array}$ \\
\hline $\begin{array}{l}\text { 2. Proprietários } \\
\text { de terras e } \\
\text { Empresariado }\end{array}$ & $\begin{array}{l}\text { - Proprietário rural e/ou } \\
\text { administradores de propriedades } \\
\text { que desenvolvem atividades } \\
\text { ambientais dentro do } \\
\text { estabelecimento; } \\
\text { - Profissionais responsáveis por } \\
\text { projetos de reflorestamentos em } \\
\text { fazendas, usinas de cana-de } \\
\text { açúcar e empresas de médio e } \\
\text { grande porte; } \\
\text { - Proprietários, associação de } \\
\text { moradores, assentados rurais, } \\
\text { comunidades rurais que } \\
\text { desenvolvem projetos de } \\
\text { reflorestamentos e coleta de } \\
\text { recursos naturais. }\end{array}$ & $\begin{array}{l}\text { - Fazendas } \\
\text { - Usinas Hidrelétricas } \\
\text { - Usinas de cana-de-açúcar } \\
\text { - Empresa de papel e celulose } \\
\text { - Comunidades rurais } \\
\text { - Assentamentos rurais } \\
\text { - Comunidades tradicionais } \\
\text { - Associação de moradores de } \\
\text { condomínios } \\
\text { - RPPN's }\end{array}$ \\
\hline $\begin{array}{l}\text { 3. Extensão } \\
\text { Florestal e } \\
\text { Rural }\end{array}$ & $\begin{array}{l}\text { - Instituições públicas e não } \\
\text { governamentais que orientam, } \\
\text { assessoram, conduzem projetos } \\
\text { de produção de mudas e/ou } \\
\text { sementes florestais; } \\
\text { - Instituições públicas e não } \\
\text { governamentais que orientam, } \\
\text { assessoram, conduzem projetos } \\
\text { de reflorestamentos, captam } \\
\text { recursos e organizam ações } \\
\text { ambientalistas nos municipais e } \\
\text { em bacias hidrográficas; }\end{array}$ & $\begin{array}{l}\text { - ONG's } \\
\text { - ITESP } \\
\text { - CATI } \\
\text { - EMBRAPA -SNT } \\
\text { - } \text { Fundação Florestal } \\
\text { - Escolas Técnicas (Agrícolas) } \\
\text { - Comitê de Bacias Hidrográficas } \\
\text { - CESP } \\
\text { - Prefeituras municipais } \\
\text { - Secretarias de Meio Ambiente } \\
\quad \text { (municipais) }\end{array}$ \\
\hline
\end{tabular}

Quadro 1 - Categorias sociais das instituições envolvidas em projetos de recuperação de áreas degradadas. 


\begin{tabular}{|c|c|c|}
\hline $\begin{array}{l}\text { CATEGORIAS } \\
\text { SOCIAIS }\end{array}$ & RESPONSABILIDADES & ATORES SOCIAIS \\
\hline $\begin{array}{l}\text { 4. Consultoria e } \\
\text { Serviços }\end{array}$ & $\begin{array}{l}\text { - Profissionais autônomos e } \\
\text { instituições privadas capacitados } \\
\text { em assessoria técnica florestal } \\
\text { e/ou elaboração de projetos de } \\
\text { reflorestamentos e RAD; } \\
\text { - Empresas e profissionais } \\
\text { capacitados em consultorias } \\
\text { relacionadas à produção de } \\
\text { sementes e/ou mudas, venda de } \\
\text { insumos florestais. }\end{array}$ & $\begin{array}{l}\text { - Empresas de serviços } \\
\text { florestais/ambientais } \\
\text { - Profissionais autônomos } \\
\text { - Associações de profissionais }\end{array}$ \\
\hline $\begin{array}{l}\text { 5. Fiscalização } \\
\text { Ambiental }\end{array}$ & $\begin{array}{l}\text { - Instituições responsáveis pela } \\
\text { fiscalização ambiental em áreas } \\
\text { urbanas e rurais; } \\
\text { - Instituições responsáveis pelo } \\
\text { licenciamento, autuação } \\
\text { ambiental, processos criminais e } \\
\text { orientações jurídicas ambientais; } \\
\text { - Instituições responsáveis em } \\
\text { vistorias de projetos de } \\
\text { ajustamento de condutas } \\
\text { ambientais ( ex.: TAC e RIMA) }\end{array}$ & $\begin{array}{l}\text { - } \text { IBAMA } \\
\text { - } \text { DEPRN } \\
\text { - Polícia Militar Ambiental } \\
\text { - Promotores de Justiça de Meio } \\
\quad \text { Ambiente (MP) } \\
\text { - Secretarias Municipais de M.A. } \\
\text { - Prefeituras Municipais } \\
\text { - CETESB }\end{array}$ \\
\hline $\begin{array}{l}\text { 6. Pesquisa e } \\
\text { Difusão de } \\
\text { Tecnologia }\end{array}$ & $\begin{array}{l}\text { - Pesquisadores e professores } \\
\text { universitários que desenvolvem } \\
\text { atividades de pesquisa e ensino; } \\
\text { - Pesquisadores que desenvolvem } \\
\text { atividades científicas, geração de } \\
\text { conhecimento e tecnologia } \\
\text { relacionada a RAD. } \\
\text { - Pesquisadores e profissionais pós- } \\
\text { graduandos, prestadores de } \\
\text { serviços àsociedade de caráter } \\
\text { científico }\end{array}$ & $\begin{array}{l}\text { - Universidades e órgãos } \\
\text { agregados } \\
\text { - Instituto de Botânica/SMA } \\
\text { - Instituto Florestal/SMA } \\
\text { - Fundação Florestal/SMA } \\
\text { - } \mathbb{P} \text { PEF } \\
\text { - EMBRAPA }\end{array}$ \\
\hline $\begin{array}{l}\text { 7. Gestão } \\
\text { Ambiental e } \\
\text { Política }\end{array}$ & $\begin{array}{l}\text { - Pesquisadores e profissionais } \\
\text { vinculados aos órgãos públicos } \\
\text { responsáveis pela gestão dos } \\
\text { recursos naturais públicos; } \\
\text { - Pesquisadores científicos } \\
\text { relacionados a projetos de } \\
\text { políticas públicas ambientais do } \\
\text { estado; } \\
\text { - Gestores e administradores de } \\
\text { unidades de conservação, APA's } \\
\text { e RPPN's }\end{array}$ & $\begin{array}{l}\text { - Instituto de Botânica/SMA } \\
\text { - Instituto Florestal/ SMA } \\
\text { - Fundação Florestal/ SMA } \\
\text { - Associação de RPPN's e APA's } \\
\text { - ONG's }\end{array}$ \\
\hline
\end{tabular}

Quadro 1 - Categorias sociais das instituições envolvidas em projetos de recuperação de áreas degradadas. 


\subsection{Resultados dos workshops regionais}

\subsubsection{Banco de dados de atores sociais em RAD}

Para cada região as informações dos atores sociais foram organizadas da forma demonstrada na Figura 3.

\begin{tabular}{|c|c|c|c|c|c|c|}
\hline \multicolumn{7}{|l|}{ Região: } \\
\hline Munıcipıo & Instıtuıçao & $\begin{array}{l}\text { Nome } \\
\text { Responsável }\end{array}$ & $\begin{array}{l}\text { Atividades } \\
\text { Desenvolvidas }\end{array}$ & $\begin{array}{l}\text { Endereço } \\
\text { Completo }\end{array}$ & $\begin{array}{l}\text { Fone/Fax } \\
\text { E-mail }\end{array}$ & Categoria Social \\
\hline & & & & & & \\
\hline & & & & & & \\
\hline & & & & & & \\
\hline
\end{tabular}

Figura 3 - Modelo do Banco de dados de atores sociais por região e categoria social.

A organização de um banco de dados de atores sociais facilitou a análise do perfil de cada workshop regional. Em cada um dos workshops o público presente atingiu a média de 100 participantes, representando as regiões de abrangência do workshop, ou seja, para o Workshop regional de Mogi Guaçu, realizado em 18 e setembro de 2002, o total de indivíduos participantes foi de 102 profissionais, que representavam 65 instituições que atuam, principalmente, na região centro e sudeste do Estado de São Paulo. 
$\mathrm{Na}$ Figura 4, pode-se observar na legenda quantificada por categoria social que, tanto a categoria de consultoria e serviços (profissionais autônomos, pequenas empresas prestadoras de serviços), quanto os órgãos de fiscalização ambiental e pesquisadores tiveram participação expressiva no Workshop regional de Mogi Guaçu.

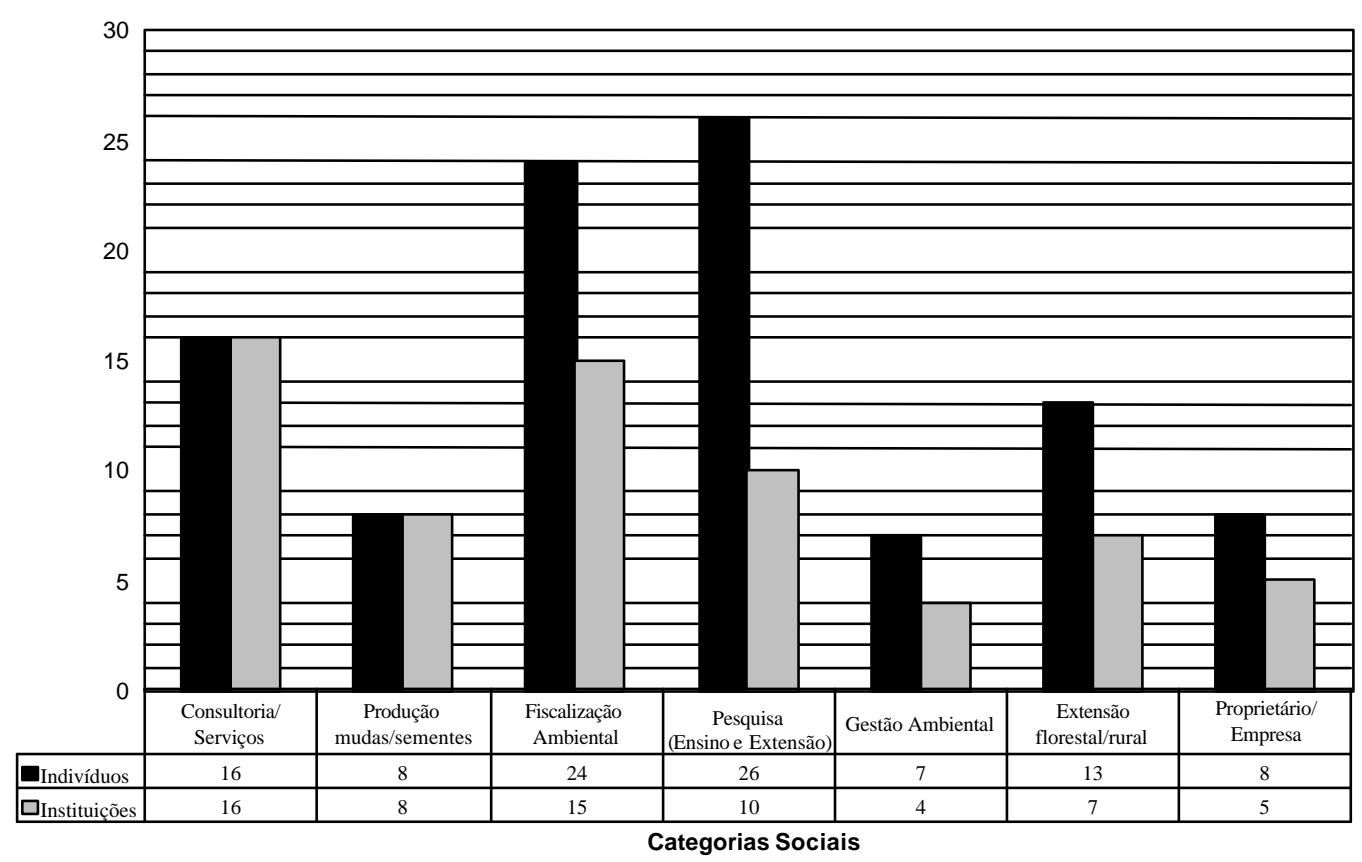

Figura 4 - Perfil dos participantes do Workshop regional de Mogi Guaçu, SP. 


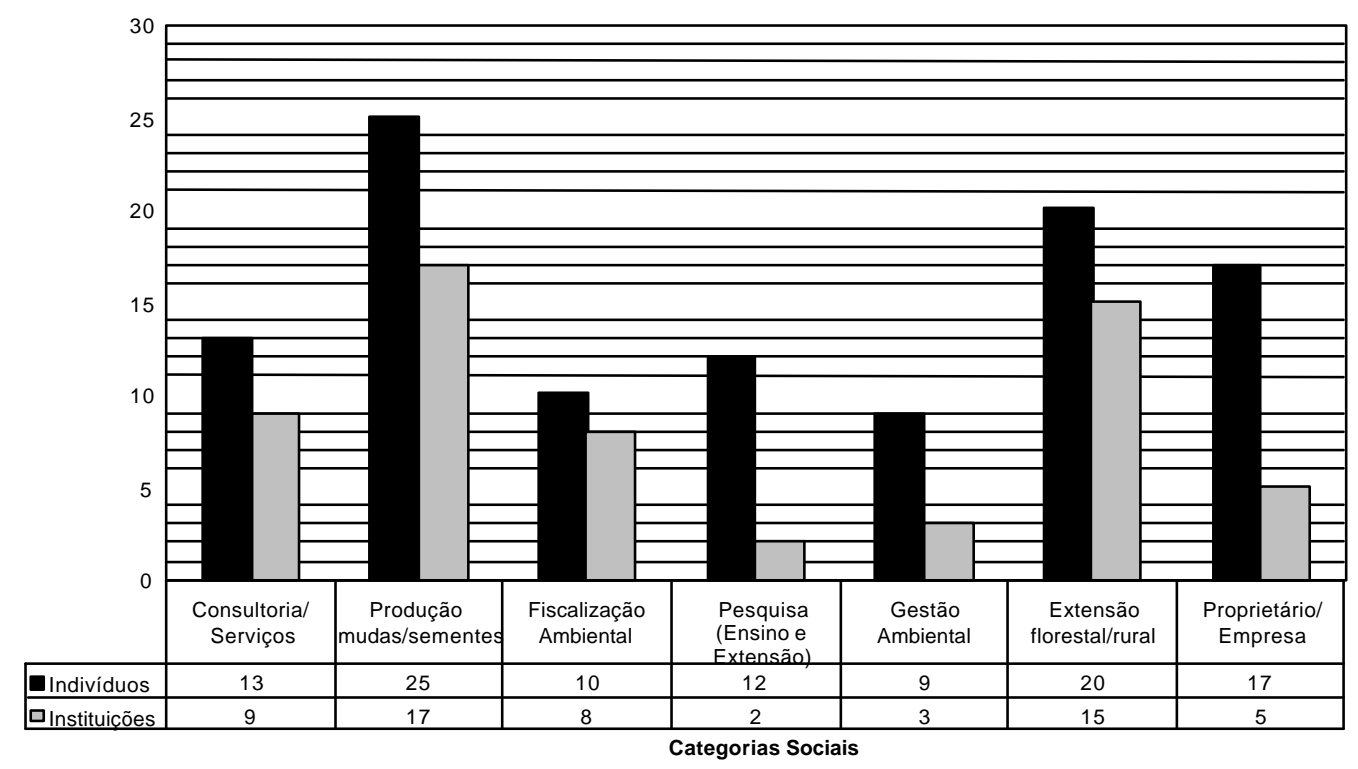

Figura 5 - Perfil dos participantes do Workshop regional de Chavantes, SP.

Para o Workshop regional de Chavantes, realizado no dia 10 de dezembro de 2002 no município localizado no sudoeste do estado, participaram 106 profissionais, que representavam 59 instituições. As instituições presentes eram, principalmente, das regiões sudoeste e noroeste do Estado, embora houvesse uma expressiva participação de instituições das regiões centro e sudeste do Estado de São Paulo. Na Figura 5 observa-se que as categorias sociais com maior número de indivíduos presentes foram as de produção de mudas/sementes (viveiristas florestais), técnicos de extensão florestal e rural e proprietários/ empresas. 
O terceiro workshop regional, realizado na região litorânea no dia 20 de fevereiro de 2002 no município de Guarujá, contou com a participação de 123 profissionais, representando 78 instituições. As instituições presentes eram principalmente das regiões do litoral sul, do litoral norte e da região sudeste (Vale do Paraíba, São Paulo - capital, e Vale do Ribeira).

Na Figura 6 observa-se que o Workshop regional de Guarujá contou com grande número de órgãos da fiscalização ambiental e de profissionais da categoria de consultoria/serviços.

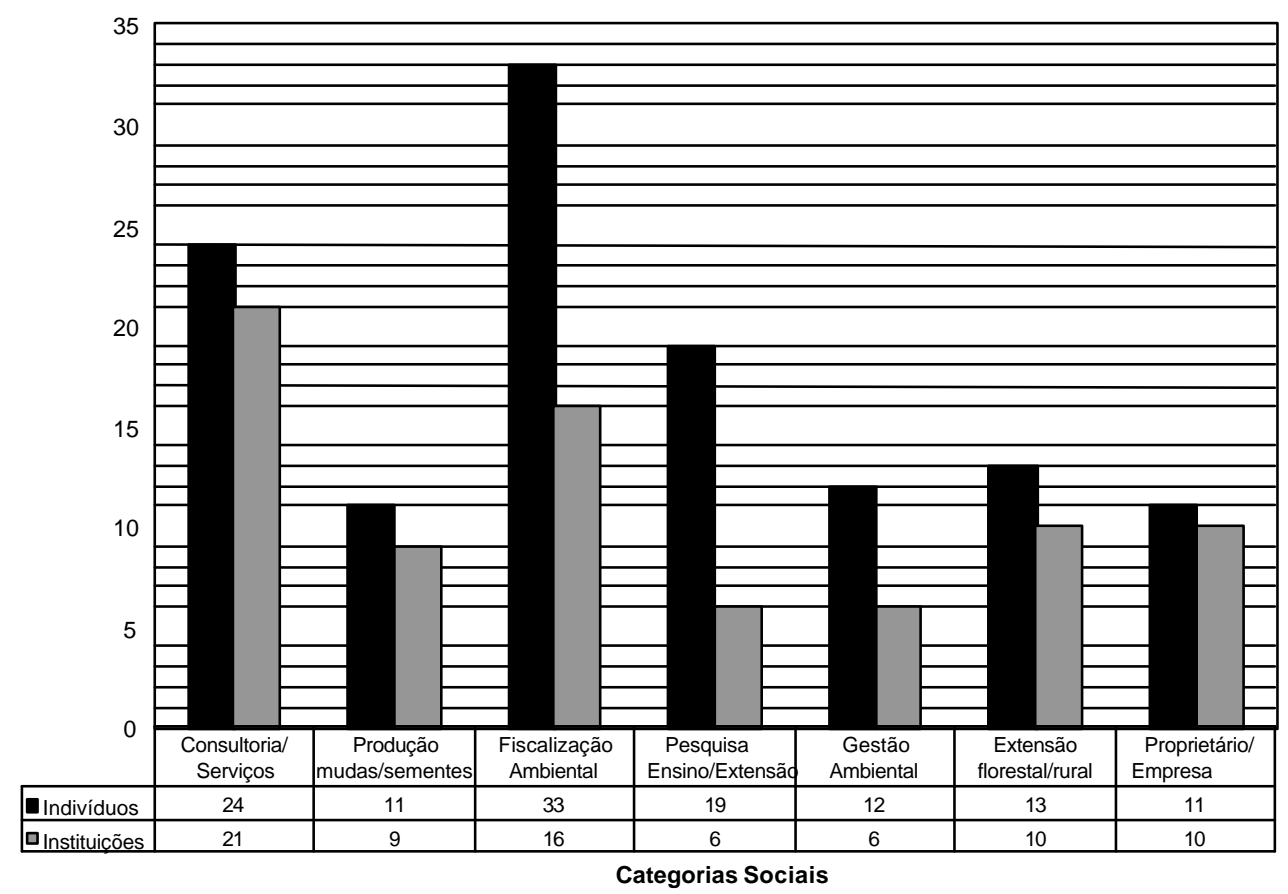

Figura 6 - Perfil dos participantes do Workshop regional de Guarujá, SP. 
Analisando as Figuras 4, 5 e 6 juntamente com os depoimentos e entrevistas, foi possível perceber que em cada região os desafios são diferentes para cada ator social na realidade local, o que se reflete nos projetos, na gestão dos recursos naturais, na fiscalização ambiental, na rede de parcerias e na presença ou ausência de instituições comprometidas com projetos de recuperação de áreas degradadas.

\subsubsection{A recuperação de áreas degradadas nas regiões ecológicas}

Para compreender o universo dos atores sociais posicionados frente à questão da recuperação de áreas degradas, optou-se por levantar informações de cada região a partir da visão de mundo dos próprios atores sociais presentes no cenário analisado, que foram somadas a dados secundários provenientes de literatura (teses, dissertações e livros) e outras fontes de informação pública (Instituto Brasileiro de Geografia e Estatística - IBGE, base de dados e artigos de jornais).

Em entrevistas com os atores, pode-se observar, fundamentalmente, que a degradação de áreas está diretamente relacionada ao histórico do uso e ocupação em cada uma das regiões. Isso se confirma para Rodrigues \& Gandolfi (2000) que afirmam ser a recuperação de áreas uma conseqüência do uso incorreto da paisagem e dos solos por todo o país, sendo assim uma tentativa limitada de remediar um dano que, na maioria das vezes, poderia ter sido evitado.

Dessa forma, destacam-se, a seguir, algumas características ecológicas e históricas juntamente com problemas apontados pelos atores sociais em cada uma da regiões ecológicas. Os dados populacionais e os principais municípios representantes de cada região estão apresentados no Quadro 3, a seguir. 


\begin{tabular}{|c|c|c|c|}
\hline Região & Municípios & População & Área $\left(\mathrm{km}^{2}\right)$ \\
\hline Noroeste & $\begin{array}{l}\text { Andradina, Araçatuba, Barretos, Catanduva, } \\
\text { Ferndópolis, São José do Rio Preto, } \\
\text { Votuporanga, Bauru. }\end{array}$ & 3.0260716 & $65.269,6$ \\
\hline Sudoeste & $\begin{array}{l}\text { Assis, Marília, Presidente Prudente, Avaré, } \\
\text { Ourinhos, Dracena,. }\end{array}$ & 1.919 .406 & $50.509,1$ \\
\hline Centro & $\begin{array}{l}\text { Campinas, Piracicaba, Ribeirão Preto, } \\
\text { Araraquara, Jaboticabal, Moji Mirim, Mogi } \\
\text { Guaçu, Sorocaba, Itapetininga. }\end{array}$ & 7.323 .976 & $71.756,16$ \\
\hline Sudeste & $\begin{array}{l}\text { São João da Boa Vista, São José dos } \\
\text { Campos, Campos do Jordão, Metropolitana } \\
\text { de São Paulo, }\end{array}$ & 1.613 .638 & $14.230,33$ \\
\hline Litoral norte & $\begin{array}{l}\text { Ubatuba, Caraguatatuba, São Sebastião, } \\
\text { Bertioga, Santos, Guarujá }\end{array}$ & 1.664701 & $7.005,31$ \\
\hline $\begin{array}{l}\text { Litoral } \\
\text { Sul }\end{array}$ & Capão Bonito, Registro, Itanhaém & 371.057 & $14.345,11$ \\
\hline
\end{tabular}

Quadro 3 - População e área das regiões do Estado de São Paulo.

Fonte: Instituto Brasileiro de Geografia e Estatística - IBGE (1997)

\subsubsection{A região centro}

A região centro do Estado de São Paulo, localizada na Serra Geral e Depressão Periférica, se caracteriza pela concentração de diferentes formações florestais (ecossistemas) que apresentam diferentes espécies arbóreas nativas, referentes a cada ecossistema. A Floresta Estacional Semidecidual - FES, a Floresta Estacional Semidecidual de "cuesta" - FCU, a Floresta Estacional Decidual - FED e o Cerrado - CE, são os ecossistemas presentes na região centro, tendo ainda a ocorrência de Matas ciliares e Matas de brejo (Barbosa \& Martins, 2003).

Para Bantin ${ }^{4}$, engenheiro florestal do DEPRN/SMA, os principais problemas referentes à devastação florestal enfrentados na região de Mogi Guaçu são devidos à supressão da vegetação nativa arbórea para a intensa atividade de mineração, abertura de pastagens e loteamentos clandestinos. 
A presença de algumas universidades como a Universidade de São Paulo nos campi do interior, Universidade Estadual de Campinas - UNICAMP, institutos de pesquisas como a Empresa Brasileira de Pesquisa Agropecuária EMBRAPA e Instituto Agronômico de Campinas - IAC, faz com que se acumule um grande número de informações de alguns ecossistemas da região, com destaque para a Floresta Estacional Semidecidual.

A Floresta Estacional Semidecidual, na região centro, apresenta um maior número de trabalhos publicados em florística e fitossociologia, podendo ser conhecidas 336 espécies arbóreas nativas características das formações florestais deste ecossistema (Barbosa \& Martins, 2003).

É nessa região que também se encontram, próximos aos centros urbanos, o maior número de viveiros florestais, como será melhor detalhado no item 4.3.3.

\subsubsection{As regiões sudoeste e noroeste}

O Cerrado e a Floresta Estacional Semidecidual são as principais formações florestais que caracterizam as regiões noroeste e sudoeste. Para a região sudoeste destacam-se ainda as Matas ciliares e Matas de brejos (Barbosa \& Martins, 2003).

Embora a Floresta Estacional Semidecidual seja bem amostrada em levantamentos florísticos e fitossossiológicos em algumas regiões, as regiões noroeste e sudeste do Estado de São Paulo apresentam poucos levantamentos de caracterização florística, provavelmente pela escassez de unidades de conservação e de remanescentes florestais nesta região (Barbosa \& Martins, 2003). 
A fragilidade dos solos combinada com a concentração de chuvas num período curto do ano e a exposição das encostas, somadas à forma de ocupação desordenada do solo, levou a região a se tornar uma das mais degradadas do Estado do ponto de vista ambiental, com predominância do grande latifúndio de pecuária extensiva. Mesmo tendo sofrido uma drástica fragmentação da vegetação original, também denominada como Mata Atlântica de Interior, o que resta das formações florestais nessas regiões são os remanescentes florestais do Pontal do Paranapanema, que abrigam rica e importante biodiversidade, com a presença de inúmeras espécies endêmicas animais e vegetais (Beduschi Filho, 2003).

Os problemas apontados pelo Dr. Bugalho ${ }^{5}$, Promotor de Justiça de Presidente Prudente, apresentam um histórico atrelado à questão agrária, à construção de barragens para instalação de usinas hidrelétricas e ao processo de ocupação desordenada de vastas extensões de terra para a pecuária extensiva (ver também Beduschi Filho, 2003). Além desses fatores, as atividades agrícolas como a soja e a cana-de-açúcar são produzidas em extensas áreas, ocupando irregularmente as áreas de Reserva Legal e Áreas de Preservação Permanente - APP, consideradas como as ações degradadoras que mais têm preocupado os órgãos de fiscalização dessas regiões.

\footnotetext{
${ }^{5}$ BUGALHO, N. (Promotoria de Justiça Regional do Meio Ambiente do Ministério Público, Presidente Prudente). Comunicação pessoal, 2002.
} 


\subsubsection{A região sudeste}

$\mathrm{Na}$ região sudeste, onde encontram-se as Florestas Ombrófila Densa, Ombrófila Mista e Floresta Estacional Semidecidual, são encontrados os ecossistemas mais bem representados quanto æ̀ características fitossossiológicas e florísticas, totalizando 396 espécies arbóreas somente da Floresta Ombrófila Densa (Barbosa \& Martins, 2003). Nessa região é também encontrada a Floresta de Araucária.

A economia da região é muito diversificada. Estão presentes as atividades agropecuárias e zonas industriais concentradas basicamente em torno das principais regiões metropolitanas e dos eixos de desenvolvimento, que geram pressões sobre as áreas naturais à medida que necessitam de recursos naturais e energia para o suprimento das atividades (Conservation International do Brasil, 2000).

Em estudo realizado pela Conservation International do Brasil (2000), foram medidos os níveis de pressão antrópica, identificando o agrupamento de municípios em áreas de pressão alta ou média-alta, com base em dados municipais sobre a densidade da população urbana e rural, produção de grãos e bovinos.

Como resultados, foram apontados dois grupos distintos para o Estado de São Paulo: 1. área de pressão alta, que corresponde às proximidades de regiões metropolitana, algumas cidades de médio porte, como São José dos Campos; e 2. áreas de pressão antrópica média-alta, com pressões específicas e que merecem cuidados especiais dentre as quais estão o vale do médio Paraíba, o vale do Ribeira e o litoral de São Paulo. 


\subsubsection{As regiões litorâneas}

Os biomas presentes nas regiões sul e norte do litoral paulista são, principalmente, a Restinga, Mangue e a Floresta Ombrófila Densa (Barbosa \& Martins, 2003).

As regiões litorâneas são as mais afetadas pela degradação ambiental devido æ̀ fortes pressões antrópicas advindas de uma exploração predatória, derrubada de manguezais, contaminação por efluentes domésticos e industriais, vazamentos de petróleo e os aterros, ações devidas, principalmente, àespeculação imobiliária (Castanheira \& Carrasco, 2003).

Para Castanheira \& Carrasco (2003), os bosques de mangue estão ameaçados pelos muitos empreendimentos na zona costeira, destacando-se as fazendas de camarão, as marinas, os pólos industriais e os condomínios que acabam por converter os manguezais para outros usos que não os de sua vocação natural.

A forte presença de comunidades tradicionais, que dependem dos recursos naturais, e a ocupação desordenada em áreas íngremes, também contribuem sobremaneira para a alteração desses ecossistemas, como no caso da ocupação que ocorre entre os municípios de Santos e São Vicente (Mantovani, 2000).

Em entrevista com Dra. Ana Paula Nogueira da Cruz, Promotora de Justiça do Ministério Público da região de Mogi Guaçu, os principais problemas enfrentados pelo Ministério Público partem da própria consciência da coletividade e do poder público. Para ela, a degradação ambiental é toda a ação que nega a qualidade de vida das populações locais, sendo a poluição um produto da ocupação desordenada de atividades econômicas, como por exemplo, atividades portuárias não planejadas e a ocupação irregular em áreas de mangue na Serra de Cubatão.

Na diversidade da região litorânea também se encontra o vale do Ribeira, onde o diagnóstico ambiental participativo realizado pela equipe do Núcleo de 
Estudos e Pesquisas Ambientais - NEPAM/UNICAMP, apontou como principais problemas ambientais enfrentados pela população local: 1 - o desmatamento, em função da bananicultura, das pastagens para criação de bovinos, da extração de palmito e de madeira; 2 - o saneamento ambiental e os lixões, que muitas vezes ocupam áreas não apropriadas ao destino dos resíduos; 3 a extração clandestina de palmito; e outros problemas destacados como o loteamento desordenado, ocupação de manguezais, turismo desordenado, todos juntos contribuindo, efetivamente, para degradação de áreas e desmatamento das formações florestais nativas (São Paulo, 1998).

\subsubsection{A Produção de mudas florestais nativas}

No que diz respeito à produção de mudas florestais no Estado de São Paulo, pode-se afirmar que há uma expressiva presença de viveiros florestais bem estruturados na região centro, o que a diferencia de outras regiões como a litorânea. Em entrevistas com técnicos da Secretaria de Obras e Meio Ambiente da Prefeitura Municipal de São Sebastião, com o proprietário do Sítio Guapuruvu de Ubatuba e o biólogo da Sociedade Amigos do Iporanga - SASIP, de Guarujá, todos afirmaram que, embora na região litorânea existam viveiros de espécies vegetais, esses não estão, na maioria das vezes, estruturados para atender projetos de recuperação florestal. Isso se deve, possivelmente, pela preferência pela produção de mudas de plantas ornamentais destinadas, principalmente, aos projetos de paisagismo nos condomínios e propriedades particulares.

Nota-se, em trabalhos publicados por Barbosa \& Martins (2003), que esses viveiros se diferenciam quanto à diversidade de produção de espécies arbóreas nativas, podendo ser encontradas desde uma única espécie produzia, no caso do palmiteiro (Euterpes edulis), cujas mudas são produzidas por 
comunidades remanescentes de quilombos do Vale do Ribeira ${ }^{6}$, até 538 espécies produzidas pelo viveiro da Bioverde, em Limeira, SP.

Muito embora haja uma grande diversidade de espécies sendo produzidas pelos viveiros no Estado de São Paulo, levantamentos apontam que $75 \%$ dos viveiros florestais produzem, em média, apenas 10 espécies de mudas florestais nativas, sendo as mais comuns: Cedrela fissilis, Schinus terebenthifolius, Hymenaea coubaril var. stilbocarpa, Chorisia speciosa, Eugenia uniflora, Pelthophorum dubium, Cariniana estrellensis, Schizolobium parahyba, Enterolobium contortisiliquume, Capaifera langsdorffi (Barbosa \& Martins, 2003). Poucos são os viveiros florestais que produzem grande diversidade de espécies. Essa dificuldade se agrava ainda mais pela sazonalidade da disponibilidade de sementes, que não garante ao mercado a distribuição de mudas durante todo $o$ ano.

$\mathrm{Na}$ Figura 7, foram reunidos os dados sobre os viveiros florestais em cada região do Estado de São Paulo que podem ser observados no ANEXO G.

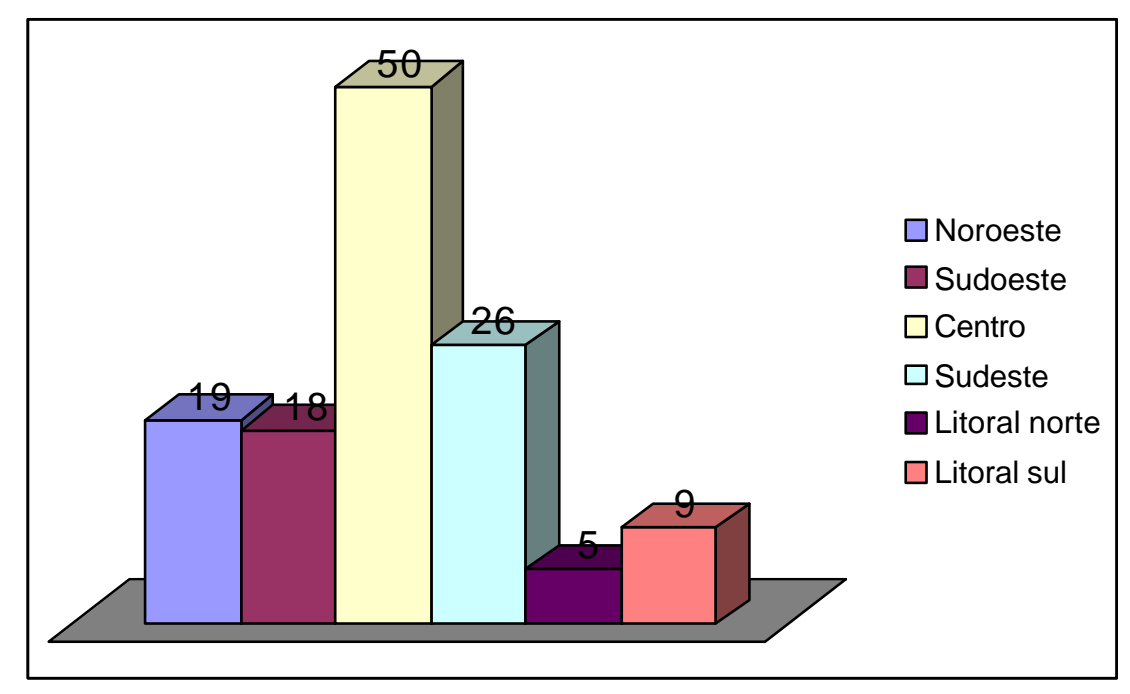

Figura 7 - Distribuição dos viveiros de produção de mudas florestais de espécies nativas nas diferentes regiões do Estado de São Paulo.

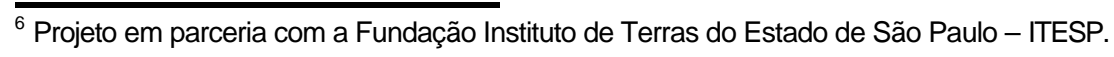




\section{DISCUSSÃO}

\subsection{As arenas de disputa e o mundo dos atores sociais da RAD}

Para se aprofundar na questão da recuperação de áreas degradadas não basta apenas levantar o histórico das causas da degradação, mas é importante que se entenda como se dá o processo que garantirá o sucesso dos projetos de plantio de mudas de árvores nativas no campo, levando em conta não somente os processos ecológicos da floresta a ser recuperada, mas também a diversidade de visões de mundo entre os atores sociais envolvidos com a recuperação de áreas degradadas.

Como já apresentado anteriormente na revisão de literatura, segundo Guivant (1998), o conceito de arenas de disputa contribui para ancorar o mundo dos atores em locais específicos. Trata-se de espaços de negociação, de conflitos, de mobilização de atores, sem que exista uma importância predefinida entre as arenas.

Todos os elementos da ação de cada um dos atores sociais, como suas posições e assimetrias, interesses e influências, motivações, interpretações e projetos, passam a ser objeto de investigação (Fuks, 1997; Guivant, 1998; Ferreira et al., 2001).

Dessa forma, mergulhamos na situação social construída pelos atores tentando responder æ̀s seguintes perguntas que nortearam o trabalho de campo desta pesquisa: 
- Quais são os pontos de vista de cada ator social relacionados ao uso da alta diversidade florística nos projetos de recuperação florestal?

- Quais são as dificuldades que enfrentam para execução de projetos de RAD?

- Quais os conflitos que se destacam entre os atores sociais e as possíveis ações de cooperação?

Para responder æ̀s questões acima, foi importante definir o que são conflitos na situação social. Para facilitar o entendimento dessa definição no âmbito deste trabalho, pode ser útil uma comparação com a sucessão ecológica na floresta, processo no qual as espécies de árvores desempenham diferentes papéis no desenvolvimento da comunidade florestal (Whitmore, 1989) que, quando agrupadas por funções semelhantes, apresentam-se como grupos ecológicos (Budowski, 1966; Finegan, 1984).

Os grupos ecológicos responderão de diferentes formas em relação àluz e aos nutrientes disponíveis no solo, podendo apresentar relações competitivas, levando até àredução da diversidade, ou relações de coexistência de espécies, onde há participação de diferentes grupos ecológicos num mesmo nicho (Kageyama \& Gandara, 2000; Rodrigues \& Gandolfi, 2000).

"As florestas se organizam lentamente através de um processo de sucessão ecológica, que se caracteriza por um gradual aumento e substituição de espécies no curso do tempo e uma ampliação da complexidade do ecossistema" (Rodrigues \& Gandolfi, 2000, p. 240).

"Durante a sucessão florestal diferentes espécies e/ou composição de espécies desempenharão distintos papéis no desenvolvimento ou manutenção da comunidade florestal" (Whitmore, 1989). 
A complexidade do ecossistema florestal permite ser comparada à complexidade da sociedade humana, onde os diferentes atores envolvidos na questão da recuperação florestal desempenham diferentes papéis no interior dessa problemática, e quando agrupados por funções semelhantes, podem ser apresentados em diferentes categorias sociais apresentadas no Quadro 1.

As categorias sociais responderão de diferentes formas em torno da legislação ambiental, das linhas de projetos e dos recursos disponíveis para execução de projetos de recuperação florestal, podendo-se observar competição ou cooperação nas ações entre atores.

Seguindo a linha metodológica desenvolvida por Ferreira et al. (2001), quando estudou os conflitos sociais em áreas protegidas no Vale do Ribeira e litoral sul, consideram-se aqui algumas das posições conflitantes entre os atores que, segundo Ostrom (1990) e Ferreira et al. (2001), quando se encontram numa reação dialógica, de modo muitas vezes circunstancial, forjam novos vínculos e clivagens. Nesse sentido, puderam ser observados diversos tipos de conflitos, priorizando-se algumas interações que este estudo enfoca.

\subsubsection{A arena da fiscalização ambiental}

Para Sampaio (2002), um dos princípios fundamentais do Direito Internacional do Meio Ambiente consiste exatamente na fixação da noção de que aquele que causa danos ao patrimônio ambiental da coletividade deve ser convocado a responder pelo seu ato. Essa idéia se reforça nas afirmações a seguir:

"Os Estados devem elaborar uma legislação nacional concernentes à responsabilidade por danos causados pela poluição e outras formas de degradação do meio ambiente, bem como destinada à estabelecer compensação à vítimas de tais danos (...)" (Nações Unidas, 1992). 
"As condutas e atividades consideradas lesivas ao meio ambiente sujeitarão os infratores, pessoas físicas ou jurídicas, a sanções penais e administrativas, independentemente da obrigação de reparar os danos causados" (Brasil, 1988).

De acordo com Dra. Carolina Nassa, em depoimento público no Workshop regional de Mogi Guaçu, realizado em setembro de 2002, o Promotor da Justiça de Meio Ambiente, vinculado ao Ministério Público, depois da promulgação da Constituição de 1988, ganhou estatus de verdadeiro advogado da sociedade, podendo atuar não só na área criminal e cível, como ocorria antes da promulgação da Constituição, mas também nos direitos difusos e coletivos. É neste conceito de direitos difusos e coletivos que se insere a proteção ao meio ambiente, assim como o direito do consumidor, direito à cidadania e àhabitação.

As regras que fixam a responsabilidade do poluidor apresentam, de um lado, um sentido preventivo, voltado a desestimular as práticas nocivas e evitar a degradação dos recursos ambientais e, de outro, um caráter restitutório, que persegue a reparação do meio ambiente lesado. Em seu escopo último, entretanto, esses dois sentidos convergem, pois tanto ao prevenir a lesão, quanto ao buscar a reparação do dano, o Direito Ambiental procura sempre salvaguardar o direito fundamental ao meio ambiente equilibrado (Sampaio, 2002). 
Para garantir esse meio ambiente equilibrado, alguns instrumentos destinados a recuperar e recompor o ambiente lesado, dos quais se destaca o chamado "Termo de Compromisso de Ajustamento de Conduta - TAC", destinam-se a adaptar a conduta dos interessados às exigências legais, mediante os processos estabelecidos. Esse Termo é uma Ação Civil Pública que pode ser proposta pelo Ministério Público, pela União, pelos Estados, Municípios e também por autarquias, empresas públicas, sociedades de economia mista, fundações, que tenham entre as suas finalidades institucionais a proteção ao meio ambiente (São Paulo, 1997).

Baseando-se na Lei 9.605/98, que dispõe sobre Crimes Ambientais, a Dra. Carolina Nassa explica ao público do Workshop regional de Mogi Guaçu quais as diferentes alternativas jurídicas que podem ser colocadas ao infrator.

"Ao tomar conhecimento de uma área degradada, através da polícia florestal, que é o modo mais comum, ou ainda através de denúncias de ONGs e outros ógãos ambientais como a CETESB, Fundação Florestal e DEPRN, o promotor de justiça poderá optar em acionar um inquérito policial, onde 0 degradador é condenado a uma pena - restritiva de direitos ou pena de multa. Ele vai ter que recuperar o dano. Nesse mesmo procedimento, temos a recuperação propriamente dita, que chamamos de recomposição do dano civil, que é a reparação do dano civil, sendo também a reparação do dano ao meio ambiente. Além disso, ele vai responder, vai ser condenado ao pagamento de uma multa ou pena alternativa.

Se aquela denúncia não configurar um crime, o promotor vai instaurar um inquérito civil (uma Ação Civil Pública), que se configura num regimento interno dentro da promotoria. $O$ inquérito civil não tem a participação de um juiz. Ele é

\footnotetext{
${ }^{7}$ Instrumento jurídico para fixação de obrigações técnicas a serem cumpridas pelo infrator do meio ambiente. Código de Defesa do Consumidor (Lei Federal n̊ 8.078, de 11 de setembro de 1990).
} 
processado dentro do Ministério Público e o inquérito pode se apresentar em três desfechos:

- No caso do inquérito civil, pode haver um acordo, o que denominamos como Termo de Ajustamento de Conduta ou "TAC";

- $\quad$ inquérito civil pode se transformar numa ação civil pública, que é a alternativa que nenhum degradador gosta, porque vai ser RÉU na ação e;

- $O$ inquérito civil pode ser arquivado, se o promotor verificar que o dano ambiental tem autoria desconhecida, por exemplo, ou que aquele dano ambiental, de certa forma, não repercute tanto na sociedade. Mas isto é questionável porque cada degradação de 1 ha ou 0,5 ha ao meu modo de ver já se configura uma degradação para o ambiente". (Em Workshop Regional de Mogi Guaçu, 18/09/2002).

Mesmo com todos essas alternativas legais, Sampaio $(2000$, p.4) faz a seguinte observação:

"Quem participa do cotidiano dos órgãos ambientais, por exemplo, sabe que é impossível o estabelecimento de critérios supostamente "neutros" de valorização dos bens e recursos sócio-ambientais, quando se analisa, por exemplo, um pedido de licença de uma mineradora, de uma hidrelétrica, de uma rodovia ou de uma indústria. Na verdade, essa impossibilidade decorre do fato de que os bens e valores em jogo quando o homem pretende modificar o meio ambiente são socialmente construídos. Como é fácil de se perceber, essa característica inerente a todo e qualquer processo de formulação de políticas ambientais torna delicada a tarefa de se avaliarem os impactos negativos das atividades econômicas, exigindo-se a adoção de 
uma postura que demanda um verdadeiro mapeamento das concepções sociais relevantes."

Para engenheiro florestal Paulo Bantim, técnico do DEPRN/SMA de Mogi Guaçu, as dificuldades vão além dos processos estabelecidos e apresentam-se no âmbito da infra-estrutura básica, onde um técnico é responsável por 17 municípios para cumprir tarefas administrativas (licenciamento e atendimento à denúncias) e monitoramento no campo das áreas autuadas.

Essa deficiência no corpo técnico do órgão público de fiscalização faz com que as ações de ajustamentos de conduta, quando estabelecidas como projetos de recuperação de áreas, nem sempre sejam acompanhadas e fiscalizadas como deveriam, fazendo com que o compromissado não siga as devidas recomendações técnicas. Neste caso, se não fosse a figura e o recurso punitivo que tem o órgão de fiscalização, seja a Promotoria Pública, o DEPRN ou a Polícia Militar Ambiental, a resistência de alguns compromissados seria muito maior.

"Se o compromissado descumprir qualquer das cláusulas, seja deixar de adubar anualmente aquela área que for replantada, ou deixar de controlar as formigas, pragas que estão atingindo aquela área, não fez o reflorestamento dentro do prazo que o Ministério Público estipulou, não ocorrendo o combinado, o Ministério Público pode executar, pode penhorar bens daquele degradador através do inquérito policial.

$\mathrm{O}$ inquérito policial é muito mais coercitivo, muito mais intimidativo que o inquérito civil. Por que? Porque ninguém gosta de passar na delegacia. Por isso, o degradador, se existe um inquérito civil contra ele no Ministério Público, psicologicamente não tem o mesmo valor do que se existe um inquérito policial na delegacia. Ambos podem conviver. 
E o que temos percebido, na prática, é que o degradador acaba recuperando muito mais rápido o meio ambiente se existe um inquérito policial. Por isso é importante essa interação entre as polícias florestais, a CETESB, os DEPRN's, noticiando o Ministério Público, a ocorrência de um dano ambiental, para que o promotor, verificando que aquilo se trata de um crime ambiental, requisite imediatamente a instauração de um inquérito policial". (Dra. Carolina Nassa, Promotora de Justiça do Ministério Público em Workshop Regional de Mogi Guaçu, 18/09/2002).

O temor àpunição está presente até mesmo para aqueles (proprietários ou empresários) que não foram autuados:

"Verifica-se que a questão legal, aliada ao temor da ação do DEPRN, da Polícia Florestal, Promotoria de Justiça, e demais instituições ligadas ao setor de meio ambiente, foi o motivo principal que levou os produtores a participar do fomento florestal da CESP, na região de Assis (SP)" (Ferretti, 2000, p.85).

O Ministério Público, na pessoa do Promotor de Justiça do Meio Ambiente, tem papel fundamental na relação dos demais órgãos de fiscalização com as instituições de produção de sementes e mudas. Se o promotor público, responsável pela questão ambiental da região, não é atualizado e disposto a enfrentar os problemas através de acordos, os conflitos e tensões tendem a aumentar, diminuindo a capacidade de cooperação entre os grupos de agentes sociais.

Um fato curioso ocorreu quando, no Guarujá, o Promotor de Justiça do Meio Ambiente se recusou a participar do workshop regional, justificando sua opção de não debater com organizações que estariam presentes, alegando 
serem aquelas as maiores infratoras e degradadoras da região. Em entrevista realizada dias antes do evento, esse promotor dizia que não aceitava contraproposta aos TAC.

“(...) Não admito uma contraproposta de compensação em outra área. A recuperação tem que ser na área que foi degradada, mas eles (os infratores) não aceitam o TAC. (...)Aqui o Ministério Público atua com muita rigidez (...) O infrator tem que consertar a área que degradou ou deslocar-se da área, pois eu mando demolir e nada permanece em pé" (Promotor de Justiça de Meio Ambiente - Forum de Guarujá. Janeiro de 2003).

Percebe-se o recurso de poder que tem o Ministério Público diante dos problemas ambientais por ele enfrentados. A ação punitiva está presente e seu entendimento sobre os recursos a serem recuperados no processo de restauração do ecossistema é bastante reduzido a leis e procedimentos jurídicos. Neste caso, o Promotor de Justiça se isola e não busca negociar com outros atores sociais.

Na região litorânea, onde a especulação imobiliária é um fator a ser considerado como uma atividade agressiva ao meio ambiente, os problemas ambientais são diferentes daqueles apresentados nas regiões do interior do Estado de São Paulo, em que a atividade principal está na agricultura e na indústria. Considerando as diferentes situações apresentadas no item 4.3.2, sobre as características das regiões do Estado, percebe-se que a ação do Ministério Público na resolução dos processos jurídicos ambientais se dá de diferentes formas. Pode-se considerar a reação do Promotor de Guarujá uma ação de represália aos especuladores da região, porém radical aos olhos dos próprios órgãos de fiscalização como o DEPRN e a Diretoria de Meio Ambiente da Prefeitura Municipal de Guarujá. 
Os órgãos de fiscalização se deparam com dificuldades para se manterem atualizados. Observa-se em diversas regiões a tentativa da Polícia Militar Ambiental e dos técnicos do DEPRN de buscar alianças com instituições de pesquisa para capacitação e atualização das informações. Apesar do esforço, há limitações físicas e estruturais para atender os processos em andamento, como licenciamento, autuação, e fiscalização regional, ocasionado uma sobrecarga de tarefas burocráticas e desfavorecendo o acompanhamento dos projetos autuados no campo.

Percebe-se que, geralmente, a sociedade, empresários, fazendeiros e demais instituições de produção e extensão apresentam críticas aos órgãos de fiscalização que se colocam na posição punitiva. As relações são delicadas e se apresentam como uma posição de confronto entre aqueles que são autuados e os que cumprem o papel de fiscalizar.

Apesar desse perfil de punição, em algumas regiões já se percebe a importância do papel do promotor em criar demanda para o uso da diversidade florística, principalmente quando há uma aproximação das ações desse ator social com outros para o desenvolvimento de atividades no município, como percebido na Usina Cerradinho em Catanduva, SP.

Percebe-se que, quando há aproximação e diálogo entre as organizações responsáveis pela fiscalização ambiental e a sociedade, as ações degradadoras se convertem em projetos e investimentos ambientais.

Para Ferretti (2000, p.54), embora haja a existência da obrigação legal para aqueles proprietários que se encontram em processo de adequação da propriedade à legislação ambiental, o que poderá garantir o sucesso e a condução das ações de recuperação de áreas é também a relação de confiança passada pelas instituições públicas comprometidas com a orientação técnica e fiscalização, a busca da qualidade de vida e a conscientização ambiental da empresa ou propriedade. 
Foi possível observar, nas regiões noroeste e sudoeste uma "coexistência positiva", ou seja, mesmo com todo recurso de poder carregado pelos instrumentos legais, existem relações de confiança entre o compromissado e o órgão de fiscalização.

No Quadro 4 são apresentadas anotações do diário de campo referentes à reunião ocorrida na Usina Cerradinho, Catanduva, SP, em 11 de março de 2003, na qual estiveram presentes cerca de 35 funcionários da Usina, 0 Promotor de Justiça de Meio Ambiente de São José do Rio Preto, e o proprietário da Usina acompanhado de sua mãe e esposa. O objetivo era avaliar a proposta de adequação ambiental apresentada pela equipe de pesquisadores do LERF - ESALQ/USP. A Usina se encontrava no processo de Ajustamento de Conduta Ambiental e deveria, dentro de um prazo determinado pela Promotor de Justiça, conduzir ações para a recuperação ambiental das áreas degradadas pelas suas atividades produtivas. 


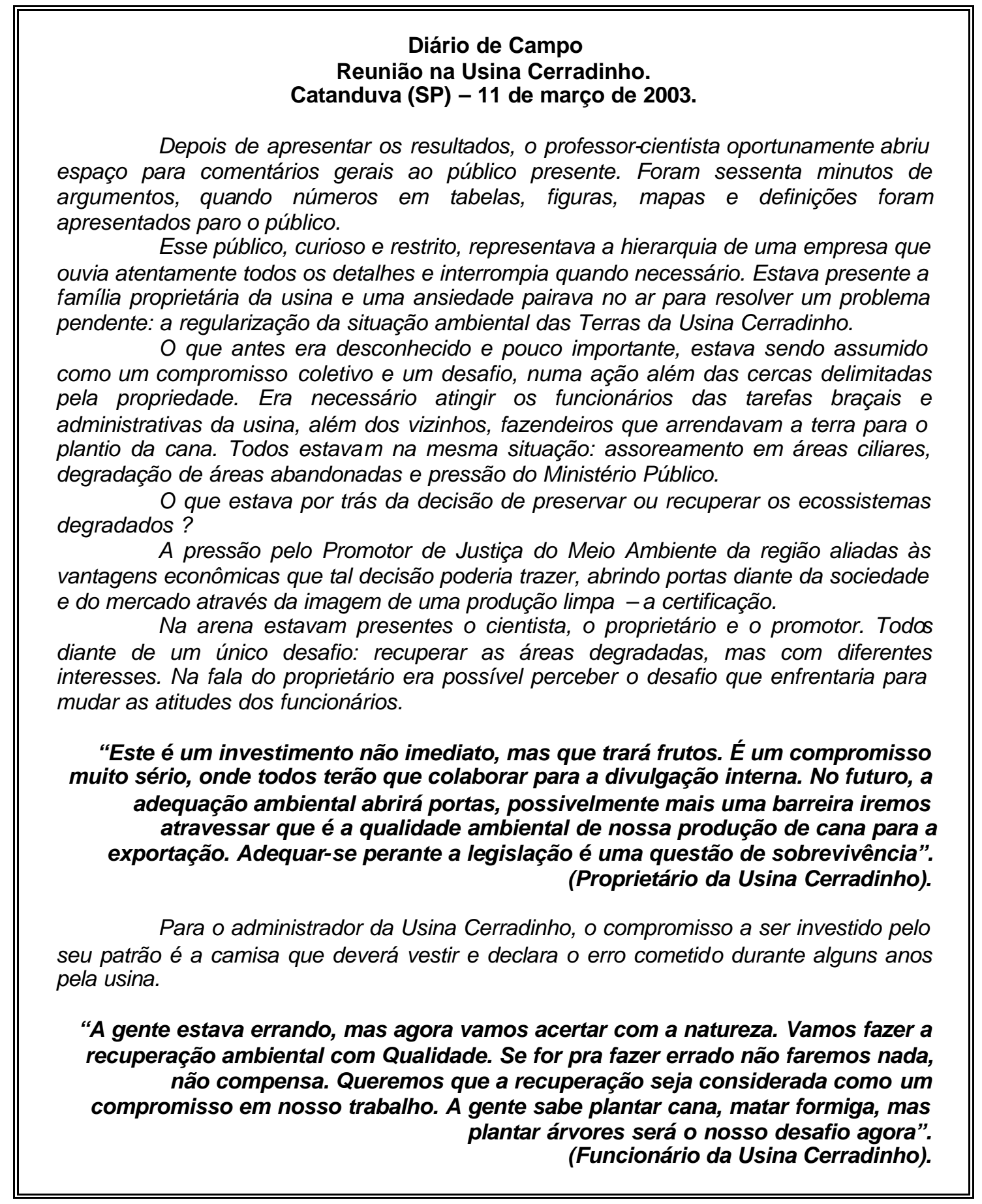

Quadro 4 - Reunião da Usina Cerradinho/Catanduva, SP. 
Os depoimentos colocados no caderno de campo reforçam a idéia de que a adequação de propriedades agrícolas e empresas passa por um processo muito mais amplo do que, somente, o reconhecimento da recuperação e conservação ambiental. Chega a apresentar-se como um desafio na mudança de atitudes que envolve funcionários e família. Muitas vezes, essas empresas buscam consolidar um programa de educação ambiental interno, criando setores e departamentos que se encarregam da reciclagem de lixo, de projetos socio-ambientais, do bem estar social dos funcionários, da adequação ambiental e monitoramento de áreas de preservação ambiental.

Os programas de educação ambiental e conservação também podem estar atrelados aos critérios de certificação que vêm sendo conduzidos por algumas empresas, como a International Paper do Brasil, a Votorantim, e a Usina Cerradinho.

Cabe ressaltar que em cada região, onde existe uma rede de instituições preocupadas com a recuperação ambiental e conservação, é necessária a existência de uma estrutura de incentivos (Beduschi Filho, 2003, p.70), entendida aqui como todo aparato técnico, financeiro e científico disponível para o processo de adequação ambiental da propriedade ou da empresa. Para Prins (1999) e Rey (1999) a estrutura de incentivos pode ser também a construção conjunta de conhecimentos entre os atores sociais envolvidos no processo.

Com essa estrutura de incentivos, verificam-se os principais motivos da articulação das organizações em realizar projetos de recuperação de áreas degradadas. Por exemplo, uma rede de cooperação que se estabeleceu entre Prefeitura de Ilha Comprida, Secretaria de Meio Ambiente e Prefeitura de Mogi Guaçu, visando a recuperação de áreas degradadas no município de Ilha Comprida, estimulou o desenvolvimento do projeto de um Viveiro Municipal de espécies florestais de restinga e manguezal em uma área que anteriormente era um problema ambiental para a população local, um antigo "lixão" no Bairro 
de Pedrinhas, criando, efetivamente, alternativas de renda e aprendizado, para mão-de-obra local, de todo o processo da produção de sementes e mudas.

\subsubsection{A arena da extensão florestal e produção de sementes e mudas}

De acordo com o artigo "Sobram viveiros de mudas, mas faltam sementes de plantas nativas" divulgado no jornal O Estado de São Paulo (2003), o problema não está mais na capacidade de produção de mudas de árvores de espécies nativas, mas sim na diversidade de espécies que estão disponíveis nos viveiros.

Estudos efetuados pelo Instituto de Botânica da Secretaria de Estado do Meio Ambiente estimam 1,3 milhões de hectares para serem revegetados neste Estado, o que significa apenas a recomposição das faixas de preservação permanente (matas ciliares), como especifica o Código Florestal. Dessa estimativa, quando considerado o plantio médio de 2.000 mudas por hectare, somente o Estado de São Paulo demandará a produção total de 2,6 bilhões de mudas de espécies arbóreas nativas (Seminário temático sobre recuperação de áreas degradadas, 2003).

Apesar dessa grande demanda por mudas, as florestas a serem implantadas devem apresentar características que garantam a qualidade florística e genética, segundo pesquisas divulgadas por autores como Kageyama \& Gandara (2000), Rodrigues \& Gandolfi (2000) o que dependerá da origem da semente.

O que se tem constatado é que a baixa diversidade e o uso das mesmas espécies nos projetos de recuperação de áreas degradadas têm comprometido o estabelecimento dos povoamentos florestais na sua diversidade florística e genética. Em outras palavras, a falta de espécies de sementes florestais nativas no mercado está prejudicando a verdadeira proposta da recuperação dos processos ecológicos da área reflorestada. 
As deficiências desse mercado de mudas são sentidas pelos próprios viveiristas a partir do momento em que a alta diversidade de espécies passa a ser uma exigência legal. Assim, sendo pressionados, por um lado pelos órgãos de fiscalização, e por outro lado pela sobrevivência no setor de produção de mudas, os viveiros com maior variedade de espécies tendem a ser mais procurados, principalmente, para atender a grandes projetos de adequação ambiental.

“(...) Sobre o mercado de mudas, nós percebemos que há dois tipos de demanda: demanda expontânea, que é a demanda de pessoas que plantam porque gostam de nativas e chega no máximo a $\mathbf{\zeta \%}$ da produção de mudas no viveiro e, a outra demanda que é a demanda induzida, que é aquela estimulada pelo DEPRN, pelo Ministério Público e chega a $75 \%$ da saída de mudas do viveiro" (Sr. Carlos Zima Júnior do viveiro Flora Cantareira de Jaguariuna/SP. Em Workshop Regional de Mogi Guaçu, 18/09/02).

Para o técnico do Programa Clickárvore da SOS Mata Atlântica, Nilson Máximo, as dificuldades são muitas para estabelecer a parceria do fornecedor de mudas com o compromissado, que deverá realizar o plantio de mudas para o reflorestamento ou ajustamento de conduta ambiental.

"Não conseguimos localizar viveiros que podem assumir este compromisso de oferecer a diversidade de espécies, principalmente, fora do Estado de São Paulo. (...) Não só o custo da muda é o problema, mas a baixa diversidade, pois muitas vezes o viveiro é muito pequenininho e não consegue trabalhar dentro daquele proposta do programa. Isto acaba previlegiando viveiros maiores. 
(...) uma outra dificuldade é a qualidade das sementes. Uma constatação é de que a maioria dos viveiros trabalham sempre com os mesmos fornecedores ou então coletam aleatoriamente, ou seja, o que encontra no caminho vai catando" (Nilson Máximo do Programa Clickárvore/SOS Mata Atlântica. Em depoimento público no Workshop Regional de Guarujá, 20/02/03).

As sementes de nativas são insumos básicos para projetos de recomposição e sua produção ocorre de forma bastante limitada quando comparada com o mercado de espécies florestais exóticas (eucalipto e pinus). Para estas espécies exóticas, verifica-se a maior organização do setor, que inclui o credenciamento de fontes de sementes florestais classificadas de acordo com critérios técnicos, como a área de coleta de sementes, área de produção de sementes em pomar (clonal ou por mudas), visando obter alta pureza genética, que garante a homogeneidade da produção resultante.

Para Coutinho et al. (2003), o fato da produção de mudas florestais nativas não estar organizada, ao contrário dos outros setores (produção de sementes de grande culturas, de oleícola, de ornamentais), ocorre, principalmente, porque o produtor não vê o retorno econômico do capital empregado, pois as sementes de espécie florestais nativas são destinadas aos projetos de recomposição florestal, ou seja, atividades que não propiciam retorno econômico imediato. 
“(...) Há falta de informação sobre sobre como armazenar as sementes, quebrar a dormência, garantir a germinação e, mesmo com laboratórios oficiais, a viabilidade de sementes não é garantida. E finalmente, o custo elevado das sementes com grandes variações de preço. Por exemplo, um quilo de jatobá pode ser encontrado por cinco reais, como vai encontrar a sessenta reais o quilo" (Sr. Carlos Zima Jr.- Viveiro Flora Cantareira. Em Workshop Regional de Mogi Guaçu).

Para a coleta de sementes é necessário pessoal qualificado que siga recomendações técnicas especificadas em trabalhos científicos e exigidas por uma legislação direcionada, efetivamente, àprodução de sementes de culturas agrícolas. Coutinho realiza uma revisão das principais leis de sementes e mudas em São Paulo e no Brasil e verifica que existem pontos críticos que podem inviabilizar a existência do produto semente. Portanto, nota-se a necessidade de adequação da legislação de sementes visando o atendimento das especificidade do setor florestal. Neste caso, a normatização de um sistema de produção de sementes torna-se um dos pontos-chave para a implementação de programas de políticas públicas em recuperação de áreas degradadas (Coutinho et al., 2003).

Alguns dos pontos críticos que podem inviabilizar o enquadramento da sementes de nativas às atuais leis são apresentados abaixo:

- A definição de espécies agrícolas não é adequada para espécies nativas;

- Nenhuma classe de semente (genética, básica, registrada ou certificada) prevista no sistema de certificação atende à espécies nativas, pois envolvem um processo de melhoramento do material. 
O problema enfrentado pelos atores sociais pela falta de uma legislação que reconheça as peculiaridades da produção de sementes de espécies nativas, somada à dificuldades do acesso ao recurso semente, são os maiores desafios do setor de produção de mudas com alta diversidade. O primeiro problema tem exigido esforços dos atores do próprio setor, juntamente com pesquisadores, na tentativa de modificar o texto da Lei 4.828/98, que dispõe sobre a produção, o comércio e a fiscalização de sementes, a ser encaminhada ao Ministério da Agricultura e que deverá substituir a Lei 6.507/77, regulamentada pelo Decreto 81.771/1978.

O segundo problema, das dificuldades de acesso ao recurso (sementes de árvores nativas), está relacionado com o que resta dos fragmentos florestais encontrados no Estado de São Paulo. Esses fragmentos, muitas vezes, se encontram em propriedades agrícolas ou em áreas protegidas por lei (unidades de conservação). Mas o que se verifica é que os fragmentos localizados em propriedades particulares nem sempre correspondem aos critérios básicos de marcação de matrizes. Um exemplo dessa natureza, segundo a Dra. Adriana de Fátima Rozza, coordenadora do Projeto Matrizes, está na dificuldade encontrada pela equipe do Projeto em selecionar e marcar as árvores matrizes, principalmente, na região noroeste e sudoeste do Estado, devido ao baixo estado de conservação em que se encontram estes fragmentos.

É interessante notar que, entre os debates ocorridos nos workshops regionais, o primeiro deles (Workshop regional de Mogi Guaçu) foi bastante expressivo quanto à visão de mundo conflitante entre os atores sociais, particularmente quando relacionado na Lei 9.985/2000, Lei do SNUC. 
“(...) Apesar de ser contraditório para algumas organizações aqui presentes, não é possível para alguém que é responsável pela gestão de algum nível, alguma política pública, não reconhecer as restrições que são impostas pela legislação que está em rigor. O SNUC é a legislação máxima federal que regulamenta a gestão das unidades de conservação e nós temos que respeitá-lo, tal como chegou ao que é hoje. E temos que construir estratégias a partir da constatação de como é hoje. (...) É possível, mesmo que com as restrições existentes, construir caminhos, nesse tema que estamos trabalhando, através da captação de recursos públicos e privados para a estratégia de conservação ex-situ.

(...) É praticamente impossível pensar que podemos ter as unidades de conservação como fonte de obtenção das sementes de nativas. Não dá para pensar neste caminho hoje, principalmente no Estado de São Paulo, por que as unidades de conservação deste estado são Áreas de Proteção Integral de uso indireto" (Lorza - Rede de Sementes Rio-SP/ Fundação Florestal/SMA. Em Workshop Regional de Mogi Guaçu, 18/09/02).

Em resposta às colocações acima, Barbosa rebate com outros argumentos. “(...) O que se pensa em torno da discussão do SNUC e da utilização das unidades de conservação como produtores de sementes é uma polêmica que está para ser resolvida, inclusive pelo CONAMA. (...) Algumas categorias do SNUC poderão ser utilizadas como uso direto desde que se trabalhe a questão de manejo. 
Existem estudos que mostram com clareza que retirar sementes de forma equilibrada destas áreas não será prejudicial ao bioma, ou àunidade de conservação. Cabe a nós trabalharmos, para cada uma destas áreas, a questão do manejo. Através de projetos demonstrativos em unidades de conservação e com todo o rigor científico que a ciência puder nos ajudar, no sentido de não ultrapassar os limites da auto sustentabilidade recomendada. (...) Desta maneira, acredito ser um canal interessante, pois não é possível pensar em preservação unicamente. É preciso pensar em conservação .

(...) Produzir ex-situ é sem dúvida uma atividade importante, mas complementar, pois estamos aquém das iniciativas a serem desenvolvidas" (Barbosa - Diretor Geral do IBt/SMA. Em Workshop Regional de Mogi Guaçu, 18/09/02).

No que tange à colheita de sementes florestais em unidades de conservação, verifica-se que dependendo de sua categoria, estabelecida pela Lei do SNUC, sob a qual se acham as unidades de proteção integral, a colheita não é permitida. No entanto, a própria lei apresenta exceções. No Quadro 5, apresentado por Lara \& Peters (2001) citado por Lorza et.al. (2003), pode-se observar as categorias de áreas protegidas e as respectivas regulamentações de uso, com base na legislação ambiental. 
É possível observar as visões de mundo conflitantes entre dois atores que compartilham a mesma categoria social, como por exemplo os gestores de unidades de conservação. Com o passar do tempo, porém, percebeu-se que as relações foram estabelecias de forma mais positivas e a visão de mundo desses atores se modificou. Nos outros workshops regionais as questões do SNUC apareceram novamente e o questionamento sobre onde marcar matrizes e a função das unidades de conservação foram discutidas. Percebe-se, contudo, que se ainda não se chegou a conclusões definitivas, existem indícios de negociação. 


\begin{tabular}{|c|c|c|}
\hline CATEGORIAS & DESCRI ÇAO & REFERENCIA \\
\hline \multicolumn{3}{|l|}{ 1. Proteção I ntegral } \\
\hline Estação Ecológica & $\begin{array}{l}\text { Permite atividades de coleta de } \\
\text { componentes do ecossistema, } \\
\text { para fins de pesquisa científica, } \\
\text { sujeita à condições e restrições } \\
\text { estabelecidas pelo órgão } \\
\text { responsável pela administração e } \\
\text { regulamentos previstos. }\end{array}$ & $\begin{array}{l}\text { SNUC, artigo } 9^{\circ}, \\
\text { parágrafos } 1^{\circ} \text { a } 4^{\circ} \text { e } \\
\text { Incisos (Brasil, 2000). }\end{array}$ \\
\hline Reserva Biológica & $\begin{array}{l}\text { Permitida atividades de pesquisa } \\
\text { com autorização prévia do órgão } \\
\text { responsável pela administração } \\
\text { da unidade. }\end{array}$ & $\begin{array}{l}\text { SNUC, artigo } 10^{\circ}, \\
\text { parágrafos } 1^{\circ} \text { a } 3^{\circ} \\
\text { (Brasil, 2000). }\end{array}$ \\
\hline $\begin{array}{l}\text { Parques Nacional (Estadual } \\
\text { e Parque Natural Municipal }\end{array}$ & $\begin{array}{l}\text { Permitida atividades de pesquisa } \\
\text { com autorização prévia do órgão } \\
\text { responsável pela administração } \\
\text { da unidade. }\end{array}$ & $\begin{array}{l}\text { SNUC, artigo } 11^{\circ}, \\
\text { parágrafos } 1^{\circ} \text { a } 3^{\circ} \\
\text { (Brasil, 2000). }\end{array}$ \\
\hline Monumento Natural & $\begin{array}{l}\text { Quando em áreas particulares, } \\
\text { permite a utilização de terras e } \\
\text { recursos naturais do local pelos } \\
\text { proprietários, desde que } \\
\text { compatível ao Plano de Manejo. }\end{array}$ & $\begin{array}{l}\text { SNUC, artigo } 12^{\circ} \\
\text { parágrafos } 1^{\circ} \text { a } 3^{\circ} \\
\text { (Brasil, 2000). }\end{array}$ \\
\hline Refúgio da Vida Silvestre & $\begin{array}{l}\text { Quando em áreas particulares, } \\
\text { permite a utilização de terras e } \\
\text { recursos naturais do local pelos } \\
\text { proprietários, desde que } \\
\text { compatível ao Plano de Manejo. } \\
\text { Ë necessánio autorização prévia } \\
\text { para pesquisas científicas. }\end{array}$ & $\begin{array}{l}\text { SNUC, artigo } 12^{\circ} \\
\text { parágrafos } 1^{\circ} \text { a } 4^{\circ} \\
\text { (Brasil, 2000). }\end{array}$ \\
\hline \multicolumn{3}{|l|}{ 2. Uso Sustentável } \\
\hline Área de Proteção I ntegral & $\begin{array}{llrr}\text { Permite o uso sustentável do } & \text { durais } \\
\text { recursos } & \text { naturais } & \text { em } \\
\text { conformidade } & \text { com diretrizes } \\
\text { estabelecidas } & \text { pelos órgãos } \\
\text { gestores. } & & \end{array}$ & $\begin{array}{l}\text { SNUC, artigo } 15^{\circ} \\
\text { parágrafos } 1^{\circ} \text { a } 5^{\circ} \\
\text { (Brasil, 2000). }\end{array}$ \\
\hline $\begin{array}{l}\text { Área de Relevante } \\
\text { Interesse Ecológico }\end{array}$ & $\begin{array}{l}\text { Permitido a utilização de Terras } \\
\text { para propriedades privadas } \\
\text { desde que compatível com as } \\
\text { normas e estrições } \\
\text { constitucionais. }\end{array}$ & $\begin{array}{l}\text { SNUC, artigo } 16^{\circ} \\
\text { parágrafos } 1^{\circ} \text { a } 2^{\circ} \\
\text { (Brasil, 2000). }\end{array}$ \\
\hline Floresta Nacional & 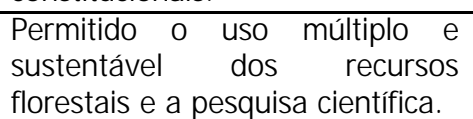 & $\begin{array}{l}\text { SNUC, artigo } 17^{\circ} \\
\text { parágrafos } 1^{\circ} \text { a } 6^{\circ} \\
\text { (Brasil, 2000). }\end{array}$ \\
\hline
\end{tabular}

Quadro 5 - Restrições legais para a colheita de sementes em áreas protegidas por legislação ambiental. 


\begin{tabular}{|c|c|c|}
\hline CATEGORIAS & DESCRIÇAO & REFERENCIA \\
\hline Reserva Extrativista & $\begin{array}{l}\text { Ermite o uso sustentável dos } \\
\text { recursos naturais por populações } \\
\text { estrativistas. Não é permitido a } \\
\text { caça amadorística ou profissional } \\
\text { e extração de recursos minerais. }\end{array}$ & $\begin{array}{l}\text { SNUC, artigo } 18^{\circ}, \\
\text { parágrafos } 1^{\circ} \text { a } 7^{\circ} \\
\text { (Brasil, 2000). }\end{array}$ \\
\hline Reserva de Fauna & $\begin{array}{l}\text { Especialmente destinada a } \\
\text { estudos técnico científicos sobre } \\
\text { manejo sustentável de recursos } \\
\text { faunísticos. }\end{array}$ & $\begin{array}{l}\text { SNUC, artigo } 19^{\circ} \\
\text { parágrafos } 1^{\circ} \text { a } 4^{\circ} \\
\text { (Brasil, 2000). }\end{array}$ \\
\hline $\begin{array}{l}\text { Reserva } \\
\text { Desenvolvimento } \\
\text { Sustentável }\end{array}$ & $\begin{array}{l}\text { Permite exploração sustentável } \\
\text { dos recursos por populações } \\
\text { tradicionais. }\end{array}$ & $\begin{array}{l}\text { SNUC, artigo } 20^{\circ} \\
\text { parágrafos } 1^{\circ} \text { a } 6^{\circ} \\
\text { (Brasil, 2000). }\end{array}$ \\
\hline $\begin{array}{l}\text { Reserva Particular do } \\
\text { Patrimônio Natural }\end{array}$ & $\begin{array}{l}\text { Permitida atividades com } \\
\text { finalidade de pesquisa científica. } \\
\text { Vetado a extração de recursos } \\
\text { naturais. }\end{array}$ & $\begin{array}{l}\text { SNUC, artigo } 21^{\circ} \\
\text { parágrafos } 1^{\circ} \text { a } 3^{\circ} \\
\text { (Brasil, 2000). }\end{array}$ \\
\hline \multicolumn{3}{|c|}{ 3. Outras áreas legalmente Protegidas } \\
\hline Reserva Legal & $\begin{array}{l}\text { Permite o uso sustentável sem } \\
\text { supressão da vegetação, desde } \\
\text { que estabelecido o Plano de } \\
\text { Manejo. }\end{array}$ & $\begin{array}{l}\text { Lei } 4.771 / 65 \text { de } 15 \text { de } \\
\text { setembro de } 1965 \text {, } \\
\text { artigo } 16^{\circ} \text {, parágrafo } \\
2^{\circ} \text {. }\end{array}$ \\
\hline $\begin{array}{l}\text { Áreas de Preservação } \\
\text { Permanente }\end{array}$ & $\begin{array}{l}\text { Permite o uso sustentável desde } \\
\text { que mantido o caráter } \\
\text { permanente da vegetação, com } \\
\text { autorização prévia de órgão de } \\
\text { fiscalização. }\end{array}$ & $\begin{array}{l}\text { Lei } 4.771 / 65 \text { de } 15 \text { de } \\
\text { setembro de } 1965 \text {, } \\
\text { artigo } 2^{\circ} \text { e } 3^{\circ} \text {. }\end{array}$ \\
\hline $\begin{array}{l}\text { Áreas Indígenas e de } \\
\text { Comunidades Tradicionais }\end{array}$ & $\begin{array}{l}\text { Os recursos genéticos e produtos } \\
\text { derivados são considerados bens } \\
\text { de interesse público, e os } \\
\text { contratos de acesso a eles se } \\
\text { farão na forma de Lei. } \\
\text { Os recursos naturais que contêm } \\
\text { o recurso genético ou produto } \\
\text { derivado são de usufruto } \\
\text { exclusivo das comunidades } \\
\text { tradicionais. }\end{array}$ & $\begin{array}{l}\text { Projeto de Lei N }{ }^{0} 4579, \\
\text { de } 1998 .\end{array}$ \\
\hline $\begin{array}{l}\text { Zonas Tampão ou de } \\
\text { Amortecimento de UC's }\end{array}$ & $\begin{array}{l}\text { As atividades realizadas devem } \\
\text { absorver o impacto sobre a } \\
\text { Unidade de Conservação. }\end{array}$ & $\begin{array}{l}\text {-SNUC, artigo } 2^{\circ}, \text { Inciso } \\
\text { XVII (Brasil, 2000); } \\
\text {-Lei de Crimes } \\
\text { Ambientais (art. 40, Lei } \\
\text { 9605, de 12/02/98); } \\
\text {-Decreto 99274, art. } 27 \\
\text { de 06/06/90. }\end{array}$ \\
\hline
\end{tabular}

Quadro 5 - Restrições legais para a colheita de sementes em áreas protegidas por legislação ambiental.

Fonte: Adaptado de Lara \& Peters $^{8}$ (2001) citado por Lorza et al. (2003)

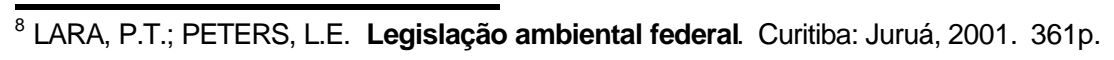


Conforme é demonstrado no Quadro 5, as categorias de Unidades de Conservação e outras áreas protegidas pela legislação ambiental não previram as possibilidades de colheita de sementes de espécies florestais nativas. Dessa forma, percebe-se que algumas categorias instituídas, principalmente, pela Lei do SNUC, poderão limitar os uso das Unidades de Conservação para essa atividade (Piña-Rodrigues et al., 2003).

Essas considerações estão sendo percebidas pelos atores sociais diretamente envolvidos com a produção de sementes e mudas e extensão florestal. Em Workshop sobre Seleção de Matrizes, realizado em novembro de 2001, organizado pelo Instituto Florestal da Secretaria de Estado do Meio Ambiente, constatourse o esforço de três Grupos de Trabalho, buscando propostas de legislação para o setor de produção de sementes florestais, normas técnicas e categorias de produção de sementes, essa última, baseando-se nos possíveis atores sociais envolvidos com a produção de sementes florestais.

Para alguns atores, a possibilidade que a colheita de sementes abrirá será de grande transformação para aqueles que, de modo informal, desenvolvem a atividade ainda em pequena escala e muitas vezes com pouca capacitação técnica e organizacional.

"Ao falar em melhorar e diversificar a renda do agricultor, e aproveitar produtos florestais não-madereiros, acredita-se que a colheita de sementes florestais nativas possa representar um diferencial, especialmente para aqueles que mantêm em suas propriedades fragmentos florestais ou trechos contínuos às unidades de conservação" (Barros, 2003).

É nesse sentido que a marcação de matrizes de árvores nativas deve ser uma atividade importante e necessária na cadeia de produção de mudas florestais. É a partir das matrizes portadoras de sementes que será possível atender aos reflorestamentos, que deixam de ser apenas o plantio de árvores 
sem critérios ecológicos, para restabelecer a recuperação dos processos naturais da floresta com alta diversidade florística e genética do local. Mas, para que isso ocorra, um caminho longo deverá ser percorrido pelos atores, que apresentam diferentes interesses e recursos de poder.

\subsubsection{A arena da política de recuperação de áreas degradadas}

O embate maior está para ser apresentado.

Em novembro de 2001, uma nova exigência legal começa a ser divulgada pelos meios de comunicação e através das atividades dos projetos da equipe do IBt/SMA. A Resolução SMA 21 (de 21-11-01) passa ser a mais atual orientação técnica para os reflorestamentos heterogêneos (ANEXO I).

Como um dos principais parceiros do IBt/SMA, o Projeto Matrizes não apenas adota a Resolução SMA 21 como um documento orientador, mas participa de sua revisão oficial, estimulando o debate público nos três workshops regionais que organizou.

Como destaca Hannigan (1995):

"Ao definir um problema ambiental, despertando a atenção da sociedade e levando à ação, os formuladores de exigências deverão empenhar-se numa variedade de atividades. Algumas dessas atividades dizem centralmente respeito à definição coletiva dos problemas potenciais, outras à ação coletiva necessária para os resolver.

Segundo este autor, após o reconhecimento de um problema ambiental, ocorre uma certa ordem de desenvolvimento desde a descoberta inicial até à política de implementação. Nesse sentido, este estudo acompanhou o processo que se configurou desde o reconhecimento do problema ambiental em questão, a degradação de áreas nas diversas regiões do Estado de São Paulo e a baixa diversidade de espécies utilizadas nos projetos de recomposição florestal, até a 
implementação das orientações na forma de Resolução através da Secretaria de Estado do Meio Ambiente.

A Resolução SMA 21 foi elaborada a partir da constatação de que os reflorestamentos realizados em 98 áreas no Estado (aproximadamente 2.500 ha) analisadas pelo IBt utilizaram cerca de 300 espécies diferentes, das quais $50 \%$ foram encontradas em apenas 03 projetos e 30 espécies mais freqüentes estavam presentes em mais de $26 \%$ dos projetos. Isto indica que a maioria das áreas utilizaram em média apenas 30 espécies, e geralmente as mesmas (Barbosa, 2002b).

Em importante Seminário Temático sobre recuperação de áreas degradadas $(2003)^{9}$, em que a Resolução SMA 21 foi levada ao debate público para se avaliar os avanços obtidos e as alterações necessárias, constatourse o importante peso da ciência na criação de exigências legais, o que pode ser observado nos depoimentos dos diferentes atores (ver ANEXO H).

Apesar de tantos depoimentos direcionados aos elogios, o processo participativo foi limitado ao grupo de especialistas comprometido com a releitura da redação da Resolução SMA 21.

Em reunião organizada paralelamente ao Seminário Temático sobre RAD (2003), cerca de 31 pessoas se encontraram em área reservada ao local do evento. Destas, $51 \%$ eram profissionais envolvidos com órgãos do governo na gestão ambiental (Instituto de Botânica, Fundação Florestal, Instituto Florestal, Jardim Botânico); 29\% representavam as universidades (ESALQ/USP, UNESP/Rio Claro, UFSCAR); 6\% eram representantes dos órgãos de fiscalização (Policia Militar Ambiental e técnico do DEPRN/Piedade, SP) e; em menor número estavam os representantes da extensão florestal (apenas um profissional da CATI); produção de sementes e mudas (Associação de Reposição Verde Tambau e FARESP) e empresa de energia (Duke Energy/Chavantes, SP).

\footnotetext{
${ }^{9}$ O Seminário temático sobre recuperação de áreas degradadas ocorreu em 12 e 13 de setembro de 2003 em São Paulo, reunindo 540 participantes. Organizado pela equipe do Instituto de Botânica/SMA.
} 
Durante a reunião tudo parecia proceder muito bem nas orientações técnicas, que estabeleciam números de espécies por áreas, lista de espécies por biomas, se não fosse a limitação da linguagem, direcionada ao público de cientistas, que se deu conta da dificuldade de entendimento apenas quando 0 Policial Ambiental se levantou e se desculpou pela incompreensão dos temas. Nesse momento foram colocadas algumas preocupações, também deixadas em um bilhete pelo Policial que em seguida se retirou. Nota-se abaixo as preocupações da Policia Militar Ambiental a serem consideradas na Resolução SMA 21:

" $1^{\circ}$ ) a inclusão do policiamento ambiental no monitoramento das áreas (objeto da Resolução);

$2^{\circ}$ ) Programas de conscientização através da Educação Ambiental nas áreas rurais;

$\left.3^{\circ}\right)$ Criação de incentivos e penalidades;

$4^{\circ}$ ) Analise da viabilidade da Resolução em áreas urbanas"

(Polícia Ambiental em reunião de atualização da Resolução SMA 21, 13/09/03).

Através dessa situação colocada, é importante destacar que a Resolução SMA 21 parece reunir com muita propriedade os anseios dos cientistas e gestores ambientais, mas pouco incorpora as preocupações de quem aplicará e fará cumprir as exigências, que são os órgãos de fiscalização e os extensionistas (ANEXO I).

A experiência destacada é confirmada por Hannigan (1995, p.53), quando afirma que no processo de criação de exigências, combinam-se esforços com outros formadores de exigências, são selecionados dados de apoio, são convencidas ideologias opostas, alargam-se fronteiras de responsabilidade, de forma sobreposta que resultam numa arena pública construída à volta dos problemas ambientais. Obviamente, esta constatação não quer dizer que as propostas do policial serão enquadradas imediatamente 
na nova redação da Resolução, mas nota-se a importância da combinação de esforços além das fronteiras da política e da ciência.

Os atores da arena da política ambiental, representados principalmente por instituições que compõem a Secretaria de Estado do Meio Ambiente (Instituto de Botânica Instituto Florestal e Fundação Florestal) e também por pesquisadores de universidades (ESALQ/UNESP/USP) envolvidos com a recuperação florestal no Estado, destacam os pontos a serem considerados em uma nova versão da Resolução SMA 21. Nota-se que as principais discussões em reuniões para a modificação da redação indicam clara preocupação técnica que pode ser observada na versão modificada da Resolução SMA 21, de 21-1101, que será encaminhada ao Secretário de Meio Ambiente Dr. José Goldemberg. As principais sugestões para alterações na Resolução estão no Anexo I.

Nessa nova versão a discussão entre os atores se concentrou basicamente em cinco considerações:

1. Sobre o número de espécies necessárias para garantir uma diversidade capaz de assegurar a auto-sustentabilidade do reflorestamento implantado. Assim, para áreas de recuperação maiores que 1ha, a nova proposta sugere 0 plantio de, no mínimo, 80 espécies arbóreas diferentes, com um limite máximo de $20 \%$ do total de mudas para qualquer espécie.

2. Sobre as espécies escolhidas que deverão representar dois grupos ecológicos: pioneiras (pioneiras e secundárias iniciais) e não pioneiras (secundárias tardias e climácicas), considerando o limite mínimo de 40\% para qualquer dos grupos.

3. Sobre as formações especiais, tais como restinga e manguezais, entre outras, as quais deverão ser tratadas em projetos técnicos, considerando a maior diversidade regional possível.

4. Outros aspectos, também consensuais, referem-se aos critérios necessários para a recuperação mediante outras técnicas que não o plantio de mudas, como por exemplo: semeadura direta, indução e/ou condução da 
regeneração natural, entre outras. Essas formas de recuperação deverão ser apresentadas em projetos, levando-se em conta: avaliação da paisagem, avaliação do histórico de degradação da área, avaliação e retirada dos fatores de degradação, avaliação dos processos de regeneração natural e aproveitamento do potencial de auto-recuperação.

5. Sobre a indicação de uma listagem de espécies florestais nativas de ocorrência nos diversos biomas do Estado de São Paulo para orientação técnica, incentivando o uso de espécies regionais.

Essa última consideração foi pautada por uma grande discussão. De um lado estavam os atores que desejavam indicar uma lista (de espécies arbóreas nativas/ bioma) permanente, mas de outro lado estavam aqueles que contestavam a permanência de uma lista que "engessaria" ações de reflorestamento quando não dispunham de espécies recomendadas em tal lista. Um consenso entre os atores de opiniões opostas se delimitou na proposta de uma atualização da listagem, anualmente, a ser realizada pela SMA.

Apesar de preocupações técnicas serem pactuadas entre os atores da arena da política ambiental, verificoutse o limitado alcance das modificações da Resolução. Como já observado por Resende (2002), de modo geral, em especial para a questão florestal, a formulação destas normas tem sido feita por grupos técnicos do Estado, com escassa participação do Poder Legislativo e, mais recentemente com alguma presença de organizações civis. Apesar de seu conteúdo avançado, principalmente no caráter técnico, carecem de representatividade social e por isso são pouco eficazes.

As limitações desta modificação na Resolução SMA não se preocuparam em: a) realizar um estudo socio-econômico para indicar o real tamanho de área a ser considerada como tamanho mínimo no emprego da diversidade de espécies e b) orientar possíveis indicadores para o monitoramento através da policia militar ambiental em parceria com a sociedade.

Numa análise voltada para 0 benefício socioambiental destes reflorestamentos com alta diversidade, destacam-se as considerações feitas no 
Art. $2^{0}$, parágrafo 2 ,sobre a admissão espécies econômicas e de princípios agroecológicos; Art. $11^{\circ}$ nos Incisos III e IV , sobre o incentivo àcapacitação de proprietários rurais e certificação de viveiros florestais, respectivamente.

\subsubsection{A arena da ciência e pesquisa}

Pesquisadores vinculados æ̀s universidades, institutos de pesquisas estaduais, organizações governamentais e não-governamentais buscam comprovar a eficiência da metodologia de recuperação florestal, desafiando velhos paradigmas da ciência. No Quadro 6 é possível perceber os argumentos utilizados pelo cientista, circundados por comprovações e comparações com a vida cotidiana. Isto faz com que a Natureza, traduzida por ele, seja compreendida e respeitada (Latour, 2000).

\section{Palestra em Workshop Regional de Mogi-Guaçu -18/09/02 Prof. Ricardo Ribeiro Rodrigues (LERF-ESALQ/USP)}

(...)O que nós chamamos de restaurar?

Restaurar na verdade nada mais é do que: a) ter um lugar disponível para recuperação; b) ter disponibilidade de muitas espécies, com comportamentos diferentes (...) para que o processo de recuperação ocorra. Temos que caminhar no sentido de chegar à estabilidade ou perpetuação, que é o que nós pretendemos. Para isso há a substituição gradual e temporal das espécies e, para que isto ocorra, tem que ter muitas espécies para que elas se substituam (...) tem que ter espécies de diferentes comportamentos para que elas possam se substituir. Na verdade, restaurar ou recuperar áreas é reproduzir um processo de sucessão florestal, onde inicia-se com pioneiras, introduz-se as secundárias e assim por diante.

$\dot{E}$ isto que acontece com a floresta. Essa nossa constatação é uma constatação da floresta, pois quando imaginamos uma floresta onde abriu uma clareira, o que acontece é exatamente isto. Abriu uma clareira, a árvore que caiu será substituída, num primeiro momento, pelas espécies iniciais de sucessão, que são as pioneiras. Num segundo momento, estas espécies pioneiras, que têm ciclo de vida curta, vão desaparecer e morrer e vão ser substituídas pelas espécies intermediárias, que por sua vez vão ceder espaço para as espécies

Quadro 6 - A teoria assumida pela arena da pesquisa sobre RAD. 
finais de sucessão. É um processo que chamamos de "dinâmica de clareiras", que não estamos reinventando, pois tudo isso é uma caracterís tica da dinâmica de floresta. Ocorre dentro da floresta nas clareiras (...)e é o que nós queremos reproduzir em nossas propostas de recuperação.

A floresta não é uma condição estática, ela é um conjunto de diferentes situações, diferentes trechos e manchas, cada situação com características particulares. $E$ por isso que temos um grande número de espécies ocorrendo dentro da floresta. Por que? Porque na floresta temos uma mancha, uma clareira que é recente, que apresenta uma condição ambiental muito distinta: maior iluminação, alta temperatura, menor umidade, etc .

Na floresta existem diferentes situações que ocorrem ao mesmo tempo em locais diferentes (...) Portanto, a floresta é um mosaico de manchas em diferentes idades. Todo trecho de floresta é, já foi ou será uma clareira. Porque felizmente as árvores nascem, crescem, florescem, frutificam e morrem.

O que queremos com a recuperação é exatamente isto. Saímos de diferentes situações e queremos chegar numa floresta com estabilidade. $E$ aqui entra um conceito que gostaria de estar reforçando com vocês... Essa é a figura que nós chamamos baseada no paradigma "clássico" da Ecologia. Ou seja, o que é definido como sucessão, de convergência de fases. Independente de onde saio, sempre chegarei a um único clímax.

Tentem me acompanhar neste raciocínio:

Independente de onde saio, sempre chegarei a um único clímax.

Este é um conceito usado em recuperação por muitos anos. Sempre buscamos na recuperação de áreas um clímax que nós idealizávamos. (...) Qual a floresta que era ideal para Mogi-Guaçu, qual é a floresta ideal para Piracicaba? E nosso propósito sempre era buscar este clímax. Então vamos planejar a nossa recuperação, pensando que um dia chegaremos a este clímax, nesta floresta idealizada. Mas o que os trabalhos têm mostrado é que não é bem assim. Inclusive aqueles dados mostrados anteriormente sobre mata ciliar(...).

O que nós aceitamos e embutimos em nossa proposta de recuperação? Não consideremos a sucessão um processo determinístico de fase. $E$ sim, estocástico, ou seja depende da história da área. Saio de pontos diferentes, mas dependendo da minha história eu posso chegar em situações diferentes. Ou seja, para o mesmo ambiente eu posso ter diferentes situações finais estáveis. Por exemplo, uma geada, ou dois anos de seca, infestação de pragas, infestação de lianas (trepadeiras), cada uma destes distúrbios direcionam a sucessão para um sentido. Mas quais destes é melhor? Há comunidades finais que são dependentes de sua história. Nós somos isto. O nosso final depende de nossa história e isto é uma característica.

Quadro 6 - A teoria assumida pela arena da pesquisa sobre RAD. 
Um importante ator social nesta arena são os pesquisadores do LERF ESALQ/USP que desenvolvem trabalhos e pesquisas em Ecologia de Restauração e estão diretamente inseridos nas concepção da Resolução SMA21, juntamente com pesquisadores do Instituto Botânico da SMA.

Gerando informações através de pesquisas realizadas por suas esquipes, o LERF e a SMA buscam interagir com a sociedade e democratizar as informações para diferentes grupos sociais, e desta maneira apresentam recurso de poder perante decisões.

Buscando descrever brevemente o 'mundo dos atores' em suas arenas específicas, é importante ressaltar que mesmo dentro da arenas existe divergência de opiniões, por exemplo em relação ao uso ou não das unidades de conservação para a coleta de sementes, buscando atender a demanda da diversidade de espécies arbóreas exigidas pela Resolução SMA-21.

A arena da ciência e pesquisa é apresentada e caracterizada pelo mundo de argumentos e dados rebuscados, na tentativa de mudanças no paradigma das pesquisas em Ecologia de Restauração. Apesar dos dados colocados à prova pelos cientistas e tecnólogos, a arena da política ambiental terá um papel fundamental para a consistência da fala do cientista. Serão as organizações com influências políticas e papéis estratégicos na formulação de legislações que farão com que os dados se transformem em normas e regras aplicáveis aos agentes de produção e reforçados pelos agentes de fiscalização.

A Rede de Sementes Florestais Rio-SP, embora tenha surpreendido a todos no primeiro depoimento em público, apresenta uma característica particular devido àforma como é estruturada. Participam dela os viveiristas, os pesquisadores da SMA, agentes de fiscalização e cientistas.

Talvez por este motivo, onde ocorre a circulação da informação de diferentes visões de mundo, o posicionamento da Rede vem sendo transformado em proposta aliada aos interesses de todas as arenas. Nesse sentido, estão sendo negociados, dentro da SMA, os locais que abrigarão as matrizes de árvores nativas para a coleta de sementes, sendo em unidades de 
conservação ou em fragmentos florestais nos diversos municípios do Estado de São Paulo.

\subsection{Os desafios da rede social em RAD}

Aqui se apresenta a principal interpretação das análises realizadas nos itens anteriores. É possível afirmar que a presença das categorias sociais estabelece uma rede de organizações envolvidas com os projetos de recuperação de áreas degradadas. As organizações não atuam de forma isolada e suas ações são pautadas por variados argumentos e recursos de poder em diferentes níveis. Observa-se que atores sociais se comunicam, alguns com afinidades em relação à posição de outros, alguns conflitando as visões de mundo entre si.

Através da pesquisa de campo e participação direta no Projeto Matrizes, é possível afirmar que a mobilização dos atores gira em torno de 04 (quatro) arenas. Estas diferentes arenas são constituídas por um grande número de atores sociais que representam seus interesses próprios, podendo ser interesses comuns entre diferentes arenas e divergentes entre o mundo dos atores de mesma arena.

Segundo Guivant (1998), essas interfaces sociais implicam em encontros face a face entre indivíduos ou grupos com diferentes interesses, níveis de conhecimento e recursos de poder. Por sua vez, essas interações levam à reconfiguração os argumentos dos atores, estabelecendo um novo patamar para novas interfaces, ou seja, novos vínculos e estratégias para alcançar objetivos em comum, o que é sugerido por autores da sociologia das organizações franceses (Andrade et al, 2002).

As quatro arenas identificadas nesse estudo são compostas pela agregação das categorias sociais. São elas: (1) arena da fiscalização ambiental; (2) arena de extensão florestal e produção de mudas florestais; (3) arena da política de recuperação florestal; (4) arena da ciência e pesquisa. 
Os principais entraves que as arenas sugeridas enfrentam estão relacionados à forma como os grupos sociais recebem, absorvem e refletem sobre métodos de recuperação florestal, legislação ambiental, eficiência da fiscalização, disponibilidade e gerenciamento dos recursos naturais.

\begin{tabular}{|c|c|c|}
\hline ARENAS & CATEGORIAS SOCIAIS & Principais responsabilidades relacionados àRAD \\
\hline $\begin{array}{l}\text { (1) arena da fiscalizaçäo } \\
\text { ambiental }\end{array}$ & $\begin{array}{l}\text { fiscalizaçáoambiental; } \\
\text { proprietários rurais; } \\
\text { empresariado. }\end{array}$ & $\begin{array}{l}\text { - Estabelecer diálogo entre Promotor ambiental, } \\
\text { técnicos do DEPRN, polícia ambiental e sociedade } \\
\text { compromissada; } \\
\text { - Atualizarse sobre métodos científicos e novas } \\
\text { legislações; } \\
\text { - Recorrer aos TAC's, garantindo qualidade dos } \\
\text { projetos de recuperação florestal. }\end{array}$ \\
\hline $\begin{array}{l}\text { (2) arena de extensão e } \\
\text { produção de mudas florestais }\end{array}$ & $\begin{array}{l}\text { produçäo; extensáo } \\
\text { florestal; consultoria e } \\
\text { serviços }\end{array}$ & $\begin{array}{l}\text { - Garantir ao mercado a diversidade de espécies } \\
\text { arbóreas nativas com alta diversidade e em } \\
\text { quantidade suficiente para atender a demanda de } \\
\text { projetos de recuperação e reflorestamentos; } \\
\text { - Seguir as orientações da legislação vigente sobre } \\
\text { recuperação de áreas degradadas; } \\
\text { - Atualizarse sobre as recomendações técnicas } \\
\text { científicas para recomendar aos clientes a melhor } \\
\text { forma de garantir os processos de recuperação e a } \\
\text { sustentabilidade da floresta implantada. }\end{array}$ \\
\hline (3) arena da politica de RAD & $\begin{array}{l}\text { Gestäo Ambiental e } \\
\text { pesquisa } \\
\text { governamental }\end{array}$ & $\begin{array}{l}\text { - Elaborar normas e recomendaçöes coerentes com a } \\
\text { realidade, objetivas e de baixo custo; } \\
\text { - Estimular a adoção das novas leis justificadas com } \\
\text { resultados científicos; } \\
\text { - Democratizar as informações para diferentes } \\
\text { categorias sociais, exercitando a participação e o } \\
\text { reconhecimento de organizações regionais. }\end{array}$ \\
\hline $\begin{array}{l}\text { (4) arena da ciència e } \\
\text { pesquisa }\end{array}$ & $\begin{array}{l}\text { Gestäo Ambiental e } \\
\text { pesquisa universitánia }\end{array}$ & $\begin{array}{l}\text { - Comprovar a eficiência da metodologia de } \\
\text { recuperação florestal desafiando velhos } \\
\text { paradigmas da ciência; } \\
\text { - Interagir com a sociedade e Democratizar as } \\
\text { informações para diferentes categorias sociais; } \\
\text { - Transformar os resultados científicos e } \\
\text { tecnológicos em resultados voltados às políticas } \\
\text { públicas. }\end{array}$ \\
\hline
\end{tabular}

Quadro 7 - Arenas e as principais responsabilidades dos atores sociais. 


\section{CONCLUSÕES}

A pesquisa realizada confirma a hipótese de que apenas a mudança do paradigma científico na Ecologia de Restauração não é suficiente para garantir a qualidade de projetos de recuperação florestal. As condições que garantem a qualidade e a perpetuação das florestas recuperadas vão além das recomendações técnico-científicas, dependendo principalmente:

- do fluxo das informações percorrendo os "fios da rede", atingindo todos os "nós" (atores sociais);

- da organização do setor de produção de sementes e mudas florestais;

- da gestão dos recursos (sementes florestais) em unidades de conservação;

- da negociação entre os atores sociais através de relações de confiança e cooperação.

Nessas entrelinhas, a Sociologia Ambiental, com a proposta de investigar as arenas de disputa, possibilitou uma análise detalhada do espaço construído pelos diversos atores sociais frente aos problemas enfrentados em suas localidades de ação relacionados ao desafio da recuperação florestal no Estado.

É certo que a área de abrangência deste estudo é bastante diversificada tanto nas características ambientais quanto no componente social. Talvez seja esta a maior dificuldade encontrada durante o caminho percorrido na busca de informações confiáveis. Mas graças a essa diversidade de componentes (ambientais e sociais), é que foi possível chegar à arenas específicas e compor a rede social. 
Cabem aqui algumas reflexões sobre os métodos utilizados para investigar a rede social em torno da questão da recuperação florestal no Estado de São Paulo. Em primeiro lugar, destaca-se o desafio de se lançar na literatura sociológica da questão, e em segundo, o de construir e adaptar procedimentos de pesquisa, utilizando como base várias experiências nas quais se desvendam as arenas, como o estudados por Ferreira (1996), Fuks (1998) e Guivant (1997), sempre relacionados aos conflitos em torno da questão ambiente e sociedade.

Muitos desafios estão colocados para os atores sociais, que foram categorizados em função de sua mobilização em torno da recuperação florestal. Essas categorias demonstram as particularidades de interesses, responsabilidades e interpretações das regras que lhes são colocadas.

No caso das sementes florestais de espécies nativas, uma grande movimentação entre os atores será necessária para garantir a satisfação da demanda que vem surgindo com as mudanças de conceitos ecológicos para a recuperação florestal. Mas essas mudanças não dependem somente da arena de extensão e produção de sementes e mudas florestais. Dependerá de uma soma de esforços entre as arenas específicas.

É o que se verificou com a marcação de matrizes de árvores nativas.

A alocação de matrizes em áreas de domínio privado tem sido a solução, enquanto as unidades de conservação de controle público apresentam-se limitadas às categorias estabelecidas pela Lei do SNUC. Embora hajam categorias de unidades de conservação que permitam a atividade exploratória com algumas restrições, será ainda necessária uma grande negociação entre todas as arenas para avançar na questão da gestão do uso das sementes florestais de espécies nativas. Nesse caso, as empresas privadas e as propriedades rurais que possuem áreas florestais conservadas estão cumprindo importante função na rede de cooperação para a marcação de matrizes de árvores nativas. O que leva um proprietário ou uma empresa a abrir suas portas para receber um projeto de marcação de matrizes, sem saber ao certo como 
suceder após a fixação destas matrizes em área de sua propriedade, é sem dúvida uma estrutura de incentivos, dos quais a certificação das empresas é um dos mais significativos. É evidente que em propriedades rurais onde verifica-se a preocupação do proprietário com a conservação dos recursos naturais, a marcação de matrizes de árvores nativas, por uma equipe da Universidade de São Paulo, é um reconhecimento de seu sentimento conservacionista, mas quase sempre está ligada à agregação de valor æ̀s suas atividades de produção.

Isso demonstra a urgência da organização do setor de produção de sementes florestais nativas, pois regionalmente a colheita de sementes já acontece e a circulação desse recurso vem sendo realizada informalmente, sem critérios legais estabelecidos e com grande variação de preços.

A Rede de Sementes Florestais Rio-São Paulo é um importante ator na organização deste setor, mas é preciso agregar aliados e ir além da formalidade apresentada ao Fundo Nacional de Meio Ambiente do Ministério do Meio Ambiente.

A questão das sementes de espécies arbóreas nativas não pode ser considerada de forma isolada, mas deve ser uma oportunidade de incentivar a adoção de uma nova postura da sociedade em relação æ̀ áreas naturais e aos problemas ambientais que degradam ecossistemas, buscando novas alternativas socio-ambientais aos proprietários, comunidades rurais e empresas.

É importante que haja um compromisso do Estado com a organização do setor de sementes de nativas, com o esforço de um trabalho cooperativo entre as instituições (públicas e privadas) que participam da rede social de projetos de recuperação de áreas degradadas.

Quanto à legislação ambiental brasileira, pode-se dizer que ela é suficiente, embora existam alguns entraves para o seu cumprimento. Um dos problemas diagnosticados é a baixa capacidade dos órgãos de fiscalização ambiental em fazer cumprir a lei, enfrentando interesses econômicos e políticos 
dos compromissados, a sobrecarga burocrática que dificulta o monitoramento e vistorias em campo, e até mesmo a falta de um compromisso da sociedade na conservação dos recursos naturais.

Apesar das dificuldades da fiscalização ambiental, verificou-se a importância dos vínculos entre Promotores de Justiça, técnicos do DEPRN e Policial Militar Ambiental. Essa aliança nas ações da fiscalização demonstra que a partir de conflitos surgem estratégias para a resolução de problemas ambientais. Foi possível observar que onde há o fluxo de informações entre esses atores da fiscalização, há também a agregação de esforços em diferentes esferas, transformando a mentalidade degradadora em ações que vão além do ajustamento de condutas, em atitudes transformadoras dentro da empresa, ou até mesmo na região.

No processo de elaboração de leis é necessária a participação de atores das diversas categorias sociais envolvidas na questão abordada.

A aplicação de leis ambientais reflete diretamente na forma como abuns atores sociais deverão se comportar e se organizar. Esse é o caso das recomendações da Resolução SMA 21 que criou a demanda pela produção de mais espécies nativas em viveiros florestais, que até então limitavam-se à produção média de 30 espécies para projeto de recuperação de áreas degradadas.

É preciso, também atentar para a linguagem utilizada na formulação de exigências legais. Na versão modificada desta Resolução, é evidente a linguagem científica, pois sua elaboração foi efetivamente trabalhada a partir de resultados de pesquisas realizadas em projetos do Instituto de Botânica/SMA e pelo Laboratório de Ecologia e Restauração Florestal da ESALQ/USP.

A constituição das arenas por um grande número de atores sociais que representam seus interesses próprios nos remete ao esquema representado a seguir. 


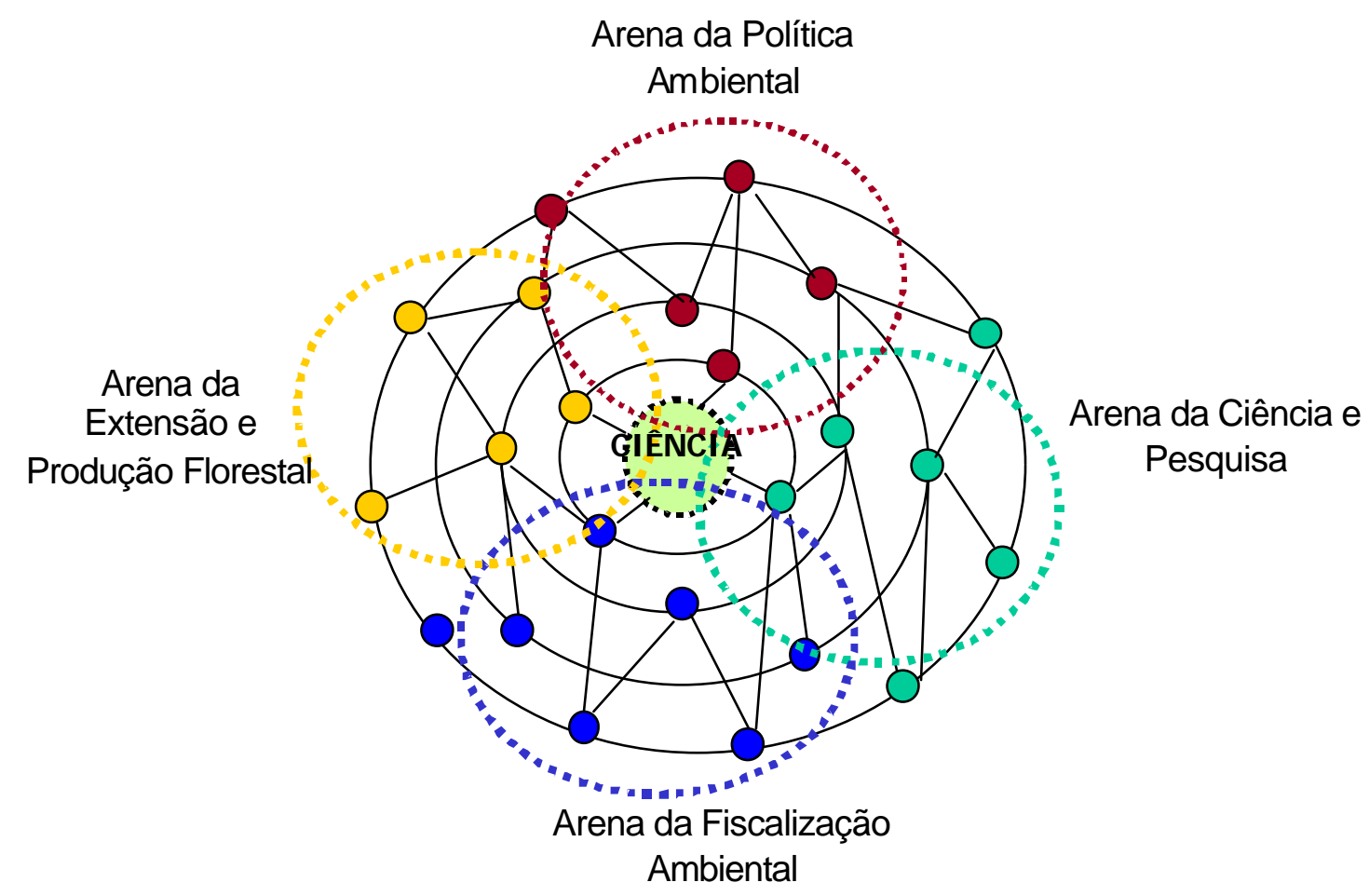

Figura 8 - A rede social em projetos de recuperação de áreas degradadas.

Nessa representação, cada círculo pontilhado representa a arena composta por agentes sociais que circulam ao redor da ciência e estão conectados por relações sociais. Pode-se observar, através das constatações empíricas deste estudo, que as condições que garantem a recuperação de áreas degradadas estão presentes numa rede social, onde os pontos são atores sociais que circulam em volta da ciência. Alguns pontos estão mais próximos do centro, representando aqueles atores que estão relacionados diretamente com a geração de dados científicos. Outros pontos, não tão próximos do centro, representam aqueles agentes que possuem capacidade de transformar os dados em leis que direcionam as ações da sociedade. 
Para concluir a representação da rede social em RAD, as instituições de produção e extensão florestal representam aqueles pontos que estão conectados fortemente garantindo a resistência dos fios. Embora não estejam tão próximos do mundo da pesquisa e da ciência, sentem diretamente as dificuldades de acompanhar a ciência e as recomendações técnicas impostas pela legislação.

Portanto, a idéia de recuperar os processos ecológicos, rompendo barreiras e conceitos bem estabelecidos da Ecologia de Restauração, não é apenas um desafio para a arena da ciência e pesquisa, mas apresenta-se como um desafio coletivo em que todos os atores são importantes para possibilitar as condições que favorecem a qualidade dos projetos de RAD. O diálogo e a informação são instrumentos que podem levar a estratégias positivas de uso dos recursos naturais em unidades de conservação e em áreas de domínio privado.

\subsection{Conclusão sobre o Programa de Capacitação do Projeto Matrizes de Árvores Nativas}

A transferência de informações geradas pelo Projeto Matrizes de Árvores Nativas foi uma tentativa de considerar a colocação de Freire (1977), ou seja, como um diálogo dos sujeitos em torno do objeto contextualizado. Buscou ser uma ação de troca e diálogo, diferente de uma situação unilateral em que é empurrada uma tendência metodológica sem colocá-la a críticas e como uma verdade única. O papel do cientista e pesquisador foi, efetivamente, de 'apresentador' de alternativas ao variado público, porém longe de ser neutro e sem tendências.

É importante destacar que as atividades de educação ambiental e capacitação devem caminhar juntos às atividades de pesquisa realizadas na Universidade, pois desta forma as ações não serão isoladas e sim complementares. Ou seja, o fluxo de comunicação entre os pesquisadores no 
desenvolvimento do projeto é essencial para descobertas que vão além do laboratório e do objeto da pesquisa, mas que transcendem fronteiras, buscando difundir conhecimentos aos demais atores sociais participantes do contexto da recuperação ambiental (Latour, 1995, 2000; Jacobi, 1997).

Os frutos desse processo possibilitaram o estabelecimento de inúmeras parcerias de diferentes formatos para a realização dos Workshops Regionais e para o reconhecimento da metodologia de restauração nas diferentes arenas e esferas de atuação das instituições regionais.

Considera-se de grande importância o mapeamento dos agentes sociais antes de iniciar as atividades de educação ambiental, mas somente no meio do caminho é que foi possível reunir informações mais consistentes sobre as organizações envolvidas na rede de RAD. Através deste mapeamento é que foi possível conhecer as demandas socio-ambientais de cada região.

O papel do Ministério Público, sem dúvida, foi destacado pela sua importância em criar demanda pela diversidade florística e genética nos projetos de adequação ambiental regional, mas isto só é possível quando há disposição deste agente de fiscalização em dialogar com os demais agentes sociais, interagindo com outras instituições que têm funções complementares, como o DEPRN/SMA e a Polícia Militar Ambiental, estabelecendo dessa forma uma rede de relações (Latour, 1995, 2000).

A marcação de matrizes se destacou pela intensa procura das instituições de produção de mudas de árvores nativas. Os viveiristas, os proprietários de áreas florestais e os consultores responderam ao Projeto de forma muito positiva, principalmente depois da realização dos Workshops Regionais. Desde então, percebeu-se a construção da confiança na atividade científica, o que refletiu no oferecimento de áreas por parte de prefeituras, proprietários de áreas florestais e viveiristas para a marcação de matrizes em suas regiões. A manifestação pelo interesse na colheita de sementes colocou em questão a estrutura das unidades de conservação e percebe-se a dificuldade de estabelecer matrizes arbóreas nestas áreas devido à restrição 
legal. Conclui-se que o processo de educação ambiental voltado para a capacitação florestal deve ser uma ação de troca de conhecimentos, buscando apoiar as iniciativas e experiências locais e regionais. É importante ressaltar que nenhum ator social é mais importante que outro na adoção de metodologias. É necessária uma ação integradora, onde atores sociais inseridos na rede social de RAD possam estabelecer acordos para gerenciar os recursos naturais e envolver a sociedade em ações conscientes e sustentáveis. 


\section{ANEXOS}


ANEXO A - Carta aos proprietários rurais e empresas.

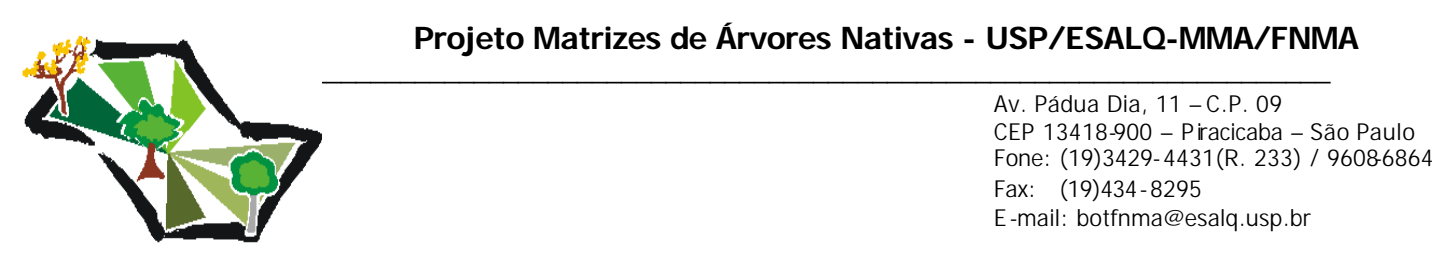

Piracicaba, Outubro de 2001.

Sr. Proprietário;

A Escola Superior de Agricultura "Luiz de Queiroz" (ESALQ/USP) e o Fundo Nacional do Meio Ambiente, do Ministério do Meio Ambiente (FNMA/MMA), estão desenvolvendo o projeto "Matrizes Arbóreas Nativas noEstado de São Paulo", que objetiva implantar trilhas em áreas florestais para marcação de matrizes de árvores nativas, visando a coletar sementes.

\title{
Porque marcar matrizes de árvores nativas?
}

O objetivo deste projeto é incentivar a produção de mudas rativas. Constata-se, que os viveiros produzem mudas nativas de um número reduzido de espécies e a partir de sementes de origem desconhecida. Melhorar a qualidade da produção é importante compromete a qualidade e o sucesso dos projetos de recuperação de áreas degradadas que tentam restaurar a biodiversidade, que foi perdida através da degradação ambiental que ocorreu no passados. Para a produção de mudas, a colheita de sementes deve ser efetuada em árvores de espécies da região, sadias, livre de doenças, de copa bem formada e localizadas em áreas florestais (propriedades, parques, reservas) em bom estado.

\section{Quem é a equipe e o que farão em sua propriedade?}

A nossa equipe é composta por pesquisadores qualificados, da Escola Superior de Agricultura "Luiz de Queiroz" - Universidade de São Paulo, que visitarão as propriedades e reservas florestais em seis regiões ecológicas do estado de São Paulo para marcar matrizes de árvores nativas. As árvores marcadas serão 'matrizes demonstrativas' para coleta de sementes para pesquisa e/ou produção de mudas regionais. Para cada espécie arbórea serão marcadas cerca de 12 árvores, sendo que em cada trilha serão marcadas aproximadamente 120 espécies. O objetivo da equipe marcar 15.000 matrizes de espécies arbóreas no camp o em todo o Estado de São Paulo.

Os resultados deste projeto serão amplamente divulgados, inclusive na intemet, para que as matrizes sejam reconhecidas e utilizadas pelos produtores de muda. O site oferecerá informações sobre as matrizes, listas das matrizes por região, informações sobre a coleta de sementes, produção de mudas e uso sustentável dos recursos naturais sem causar danos a própria mata. Também serão realizados eventos regionais junto aos agentes de fiscalização e os demais pessoas envolvidas com a produção de mudas e elaboração de projetos de recuperação florestal. Para realizar o seu cadastro, entre em contato ou encaminhe sua carta de interesse.

Agradecemos desde já a sua colaboração, que é de grande importância para que este projeto possa ser implantado em sua região, e colocamos a disposição nosso contato para maiores informações. Atenciosamente,

\author{
EQUI PE DO PROJ ETO MATRI ZES DE ÁRVORES NATI VAS \\ LABORATÓRIO DE ECOLOGIA E RESTAURAÇÃO FLORESTAL \\ ESALQ/ USP- MMA/ FNMA
}




\section{ANEXO B - Carta para autorização da marcação de matrizes.}

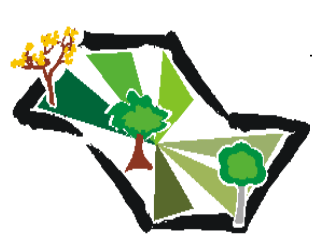

Projeto Matrizes de Ánvores Nativas - USP/ ESALQ-MMA FNMA

Av. Pádua Dia, 11 - C.P. 09

CEP 13418-900 - Piracicaba - São Paulo

Fone: (19)3429-4431(R. 233) / 96086864

Fax: (19)434-8295

E-mail: botfmma@esalq.usp.br

Piracicaba, 01 de Outubro de 2002.

\section{À}

EUCATEX FLORESTAL

A/C

Sr. MARCELO BRISOLLA

Prezado Sr. :

Conforme contato realizado no dia 18 p.p., durante o Workshop Regional "Espécies Florestais Nativas para Projetos de Recuperação de Áreas Degradadas no Estado de São Paulo", vimos por meio desta solicitar a confirmação de que a EUCATEX FLORESTAL tem interesse em apoiar o Projeto "Matrizes de Árvores Nativas", indicando fragmentos florestais para a marcação de matrizes de espécies arbóreas nativas.

O projeto "Matrizes de Árvores Nativas", conduzido pelo Laboratório de Ecologia e Restauração Florestal (LERF) da Escola Superior de Agricultura "Luiz de Queiroz" (ESALQ/USP) e Fundo Nacional do Meio Ambiente (FNMA/MMA), visa promover a diversificação e regionalização da produção de sementes e mudas de espécies arbóreas nativas, contribuindo para a restauração da cobertura florestal do Estado de São Paulo, com diversidade florística e genética e flora regional, de forma a garantir a perpetuação dessas áreas recuperadas e portanto o sucesso de projetos de recuperação de áreas, principalmente ciliares.

Neste sentido, gostaríamos de salientar que disponibilizar matrizes para coleta de sementes em suas propriedades representa uma importante contribuição da EUCATEX FLORESTAL para que os objetivos do projeto sejam plenamente alcançados.

Vale destacar que o acesso a essas matrizes para coleta de sementes deverá ser apenas por viveiristas ou coletores cadastradas de sementes da região e a ordenacão dessa atividade, para não se tornar impactante, para não permitir iniciativas de biopirataria, para definir as condições de acesso e outras deverão ser estabelecidas pela própria empresa.

Mas atentamos que o acesso æ̀ matrizes não deverá ser impedido, apenas ordenado e temos recomendado uma porcentagem de coleta de no máximo $20 \%$ das sementes produzidas por indivíduo e uma taxa de pagamento de acesso de $20 \%$ das sementes coletadas pelos viveiristas nas matrizes de propriedade da Empresa.

Prof. Dr. Ricardo Ribeiro Rodrigues

Coordenador do Projeto Matrizes de Árvores Nativas

LERF/ESALQ/USP- FNMAMMA 


\section{ANEXOC - Roteiro de entrevistas para palestrantes dos workshops regionais.}

\section{QUESTIONÁRIO 1}

A- Órgãos de Fiscalização -
Promotores de Justiça do Meio Ambiente
Ator Social A1: Promotora de Justiça de Mogi-Guaçu, SP.
Ator Social A2: Promotor de Justiça de Presidente Prudente, SP.
Ator Social A3: Promotor de Justiça de Guarujá, SP.
Ator Social A4: Promotor de J ustça de Santos, SP.
a) Qual é o papel desempenhado pelo Ministério Público relacionado a questão ambiental e
especificamente relacionado a recuperação de áreas degradadas?
b) Quais são os principais problemas ambientais enfrentados na região e quais as principais leis e
resoluções são utilizadas para solucionar estes problemas?
c) Quais os órgãos públicos e/ou privados que atuam junto a Promotoria Ambiental nas ações de
ajustamento de conduta ambiental?
d) Quais as principais dificuldades enfrentadas pela Promotoria Ambiental?
e) Quais as medidas poderiam ajudar na eficiência do trabalho desenvolvido pelo Ministério Público
para implantação de projetos de recuperação de áreas degradadas que garantam a formação da
vegetação com diversidade de espécies regionais?
f) Que mensagem gostaria de passar para este evento, onde estão presentes técnicos da área
florestal, viveiristas produtores de mudas, pesquisadores, ONG's, empresas públicas e privadas da
área florestal?




\section{B- Órgãos de Fiscalização \\ Técnicos do Departamento Estadual de Proteção dos Recursos Naturais- DERPN/SMA}

Ator Social B1: Técnico do DEPRN de Mogi-Guaçu, SP.

Ator Social B2: Técnico do DEPRN de Bauru, SP.

Ator Social B3: Técnico do DEPRN de Santos, SP.

a) Qual é o papel desempenhado pelo DEPRN relacionado a degradação ambiental e especificamente a recuperação de áreas degradadas e como atua junto a Policia Ambiental e Ministério Público?

b) Quais são os principais problemas ambientais enfrentados pelo DEPRN e qual é o panorama da degradação ambiental e florestal na região?

c) Quais as principais leis e resoluções são utilizadas para solucionar estes problemas?

d) Qual é a importância da Resolução/SMA 21 emprojetos de recuperação ambiental?

e) Quais as recomendações que o DEPRN indica em projetos de recuperação florestal? Estes projetos têm apresentado sucesso no campo e tem garantido a recuperação da vegetação nativa?

f) Quais as medidas ou instrumentos poderiam ajudar na eficiência do trabalho desenvolvido pelo DEPRN na questão ambiental?

QUESTIONÁRIO 3

\section{C- Agentes de Extensão}

Ator social: EMBRAPA - Transferência de Tecnologia/ Ponta Grossa, RS.

a) quais são as atividades desenvolvidas pela Embrapa relacionadas com a produção de sementes e mudas de espécies arbóreas nativas?

b) Quais são os BIOMAS que a Embrapa desenvolve atividades relacionadas ao fomento de mudas florestais nativas? Porque incentivar a produção nestes BIOMAS? (Biomas: Floresta de Araucária, Cerrado)

c) Como pode ser organizadas a produção de sementes e mudas florestais para recuperar áreas degradadas? Quais instrumentos poderão ser desenvolvidos para atender a demanda?

d) O que a Embrapa considera como qualidade na produção de mudas florestais nativas?

e) Como este projeto (Fomento na Produção de Mudas de Espécies Nativas/CNPq) poderá beneficiar o proprietário de área florestal e incentivá-lo a conservar formações florestais nativas?

f) Quais as dificuldades que o projeto enfrenta e como estas dificuldades podem ser solucionadas? 


\section{D- Agentes de Extensão e Produção de mudas florestais nativas}

Ator social: Rede de Sementes Rio - SP

a) Qual é a proposta (objetivos) da Rede de Sementes Florestais para a região do Rio de J aneiro e São Paulo?

b) Quais são os parceiros deste trabalho e como estes têm se organizado para a produção de sementes e/ou mudas florestais?

c) Existe a preocupação com o uso da diversidade de espécies florestais nativas e com a diversidade genética de cada tipo florestal onde atua a Rede de Sementes? Quais as dificuldades para garantir qualidade de diversidade florística?

d) Quais as estratégias e medidas poderiam ajudar na eficiência do trabalho desenvolvido pela Rede de Sementes Rio - SP garantindo a produção de sementes diversificada e com qualidade para projetos de recuperação de áreas degradadas?

\section{E- Agentes de Extensão e Produção de mudas florestais nativas}

Ator social E1: Associação de Reposição Flor. Flora Cantareira, Jaguariúna, SP. Ator social E2: Setor Ambiental da Vale do Rio Doce, ES.

Ator social E3: Associação de Reposição Florestal Flora Vale, Marília, SP.

Ator social E4: Associação de Reposição Florestal Florespi - Piracicaba, SP.

Ator social E5:Sociedade dos Amigos do I poranga - SASIP, Guarujá, SP.

Ator social E6: SOS Mata Atlântica, Litoral, SP.

a) Quais são as demandas na produção de mudas e quais espécies são mais procuradas?

b) Quais as principais dificuldades na produção de mudas para atender a demanda?

c) Como são enfrentadas as dificuldades desta associação/ empresa para garantir a qualidade das mudas e diversidade florística?

d) Quais são os parceiros do trabalho desenvolvido e como estes têm incentivado na produção de sementes e/ou mudas florestais?

e) Que mensagem gostaria de passar para este evento, onde estão presentes técnicos da área florestal, promotores, polícia ambiental pesquisadores, ONG's, empresas públicas e privadas da área florestal? 


\section{ANEXO D - Relação de entrevistados.}

a) Órgãos de Fiscalização - Promotores de Justiça do Meio Ambiente

- Promotora de Justiça de Mogi-Guaçu, SP.

- Promotor de Justiça de Presidente Prudente, SP.

- Promotor de Justiça de Guarujá, SP.

- Promotor de Justiça de Santos, SP.

b) Órgãos de Fiscalização - Técnicos do Departamento Estadual de Proteção dos Recursos Naturais- DERPN/SMA

- Técnico do DEPRN de Mogi-Guaçu, SP.

- Técnico do DEPRN de Bauru, SP.

- Técnico do DEPRN de Santos, SP.

- Técnico do DEPRN de Piracicaba, SP.

c) Órgãos de Fiscalização - Policia Militar Ambiental e IBAMA

- Batalhao da Polícia Militar Ambiental de Itaberá, SP

- Batalhao da Polícia Militar Ambiental de São José do Rio Preto, SP

- Batalhao da Polícia Militar Ambiental de Guarujá, SP

- Técnico do IBAMA/ Flona de Lorena

- Técnico do IBAMA/ lona de Iperó

d) Agentes de Pesquisa e Extensão

- LERF-ESALQ/USP - (Professores, pesquisadores, estudantes e funcionários)

- $\quad$ IBt/SMA - ( Diretor Geral e pesquisadores)

- EMBRAPA - Transferência de Tecnologia/ Ponta Grossa, RS.

- EMBRAPA - Transferência de Tecnologia/ Campinas, SP.

- EMBRAPA Meio Ambiente/ Jaguariúna, SP

- EMBRAPA Monitoramento por Satélite/ Campinas, SP.

e) Agentes de Extensão e Produção de mudas florestais nativas

- Associação de Reposição Flor. Flora Cantareira, Jaguariúna, SP.

- Setor Ambiental da Vale do Rio Doce, ES.

- Associação de Reposição Florestal Flora Vale, Marília, SP.

- Associação de Reposição Florestal FLORESPI - Piracicaba, SP.

- Sociedade dos Amigos do Iporanga - SASIP, Guarujá, SP.

- SOS Mata Atlântica, Litoral, SP.

- Rede de Sementes Rio - SP 


\section{ANEXO E - Programação do Workshop regional de Chavantes, SP.}

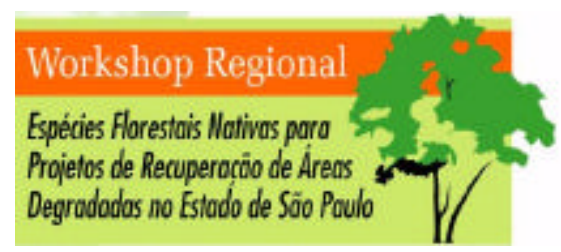

Local: Duke Energy International Geração Paranapanema

Usina Hidrelétrica Chavantes/ Chavantes, SP Data: 12 de dezembro de 2002

\begin{tabular}{|c|c|}
\hline & PROGRAMAÇAOO \\
\hline $\begin{array}{l}8: 30-9: 00 \\
9: 00-9: 30\end{array}$ & $\begin{array}{l}\text { CREDENCIAMENTO E DISTRI BUI ÇÃO DO MATERI AL DO WORKSHOP } \\
\text { Abertura e Composição da Mesa } \\
\text { Ricardo Ribeiro Rodrigues - LERF/LCB - ESALQ/USP } \\
\text { Luiz Mauro Barbosa - CINP/ Secretaria de Estado do Meio Ambiente } \\
\text { Cesar Teodoro - Duke Energy International Geração Paranapanema } \\
\text { Edison Bolson - Embrapa Transferência de Tecnologia/ Escritório de Negócios de Campinas }\end{array}$ \\
\hline PARTE I - ENFC & OQUE NA ADEQUAÇAO E FISCALIZAÇÃO DE PROJ ETOS DE RECUPERAÇÃO DE ÁREAS DEGRADADAS \\
\hline $9: 30-10: 10$ & $\begin{array}{l}\text { Recuperação de Áreas Degradadas: Estado atual e o que precisa mudar. } \\
\text { Dr. Luiz Mauro Barbosa - CINP/SMA }\end{array}$ \\
\hline 10:10 - 10:50 & $\begin{array}{l}\text { J ustificativas para o uso de espécies florestais regionais com alta diversidade florística e genética. } \\
\text { Prof. Dr. Ricardo Ribeiro Rodrigues- Departamento de Ciências Biológicas-LERF/ESALQ/USP }\end{array}$ \\
\hline $10: 50-11: 20$ & INTERVALO \\
\hline $11: 20-11: 50$ & $\begin{array}{l}\text { Panorama da Degradação Ambiental e Recuperação Florestal da Região. } \\
\text { Dr. Nelson Roberto Bugalho - Promotor de Justiça Regional do Meio Ambiente do Pontal do } \\
\text { Paranapanema, SP. }\end{array}$ \\
\hline 11:50- 12:20 & $\begin{array}{l}\text { Exigências técnicas para aprovação de projetos de recuperação de áreas degradadas } \\
\text { Engo. Agrônomo Ricardo Leonel D'Ércole- Diretor da Regional Centro Oeste Paulista./ DPRN } 6 .\end{array}$ \\
\hline $12: 20-12: 50$ & DEBATE PARTE I \\
\hline $13: 00-14: 00$ & ALMOÇO \\
\hline PARTE II - EN & FOQUE NA PRODUÇÃO DE SEMENTES E MUDAS DE ÁRVORES NATIVAS \\
\hline $14: 05-14: 30$ & $\begin{array}{l}\text { A contribuição do Projeto Matrizes de Árvores Nativas para a Recuperação de Áreas Degradadas no } \\
\text { Estado de São Paulo. } \\
\text { Enga }{ }^{2} \text {. Agrônoma Adriana Rozza-LERF/ESALQ/USP -FNMA/MMA }\end{array}$ \\
\hline
\end{tabular}

\section{Informações:}

Laboratório de Ecologia e Restauração Florestal -LERF/ESALQ/USP Av. Pádua Dia, 11 - C.P. 09

CEP 13418-900 - Piracicaba - São Paulo

Fone: (19) 3429-4431 (R. 233) Fax: (19) 4334-8295

E-mail: botfnma@esalq.usp.br
Embrapa Transferência de Tecnologia/Campinas Av. Anchieta, 173 -cj 41 e 42 CEP 13015-100 - Campinas, SP Fone: (19) 3232-1955 Fax: (19) 3232-1707

E.mail: sac@campinas.snt.embrapa.br 


\section{ANEXO E - Programação do Workshop regional de Chavantes, SP.}

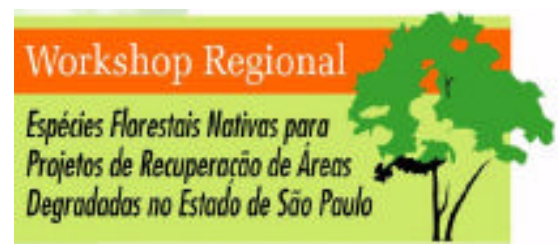

Local: Duke Energy International Geração Paranapanema

Usina Hidrelétrica Chavantes/Chavantes, SP. Data: 12 de dezembro de 2002.

\section{PROGRAMAÇAO}

14:30 - 14:55 Programa de Revegetação da Duke Energy

Eng ${ }^{\circ}$. Agrônomo Ivan Takeshi Toyama - Duke Energy Intemational Geração Paranapanema

14:55- 15:20 Produção de Sementes de Espécies Nativas Engo. Agrônomo André Nave - LERF-ESALQ/USP

15:20 -15:45 As deficiências e potencialidades da coleta de sementes florestais nativas na Região de Assis, SP. Edvaldo Furlan - Instituto Florestal / Estação Ecológica de Assis.

15:45 - 16:05 INTERVALO

16:05 - 16:30 Principais demandas para a produção de mudas de nativas com diversidade genética e florística. Eng ${ }^{\circ}$ Florestal Cláudio Augusto Bertolucci - Associação de Recuperação Florestal do Médio Paranapanema/ Flora Vale

16:30 -16:55 Rede de Sementes Florestais Rio- São Paulo: parcerias para a produção de sementes e mudas florestais nativas.

Eng . Florestal Renato Farinazo Lorza - Fundação Florestal do Estado de São Paulo- FNMA/MMA.

16:55 - 17:30 DEBATE PARTE II

17:30 - 17:45 ENCERRAMENTO.

\section{Informações:}

Laboratório de Ecologia e Restauração Florestal -LERF/ESALQ/USP Av. Pádua Dia, $11-$ C.P. 09

CEP 13418-900 - Piracicaba - São Paulo

Fone: (19) 3429-4431 (R. 233) Fax: (19) 4334-8295

E-mail: botfnma@esalq.usp.br
Embrapa Transferência de Tecnologia/Campinas

Av. Anchieta, 173 -cj 41 e 42

CEP 13015-100 - Campinas, SP

Fone: (19) 3232-1955 Fax: (19) 3232-1707

E.mail: sac@campinas.snt.embrapa.br 


\title{
ANEXO F - Ficha de inscrição para os workshops regionais.
}

\author{
PREENCHA A FICHA E ENCAMINHE AOS ENDEREÇOS ABAIXO
}

Nome:

Instituição:

Cargo:

Atividade que desenvolve:

Endereço para

correspondência:

Cidade: Estado: CEP:

Fone/Fax: Celular:

E-mail:

Através de que veículo de comunicação obteve informações sobre este evento?

( ) site na internet Qual?

( ) mensagem de e-mail ( ) jornal ( ) revista ( ) rádio

( ) outras formas Qual?

Justifique seu interesse em participar deste Workshop detalhando, brevemente, sua área de atuação:

Faça sua inscrição através:

- Dos sites: www.embrapa.br/snt ou www.campinas.snt.embrapa.br

- Do Fax: (19) 32321707 - Embrapa Transferência de Tecnologia/Campinas, SP.

Informações Adicionais:

- (19) 3232-1955 ou 3231-4316 - Embrapa Transferência de Tecnologia/Campinas, SP.

E-mail: sac@campinas.snt.embrapa.br (Vera)

- (19) 3429-4431 r.228 ou 233 - LERF/ESALQ/USP.

E-mail: botfnma@esalq.usp.br (Liviam ou Adriana) 
ANEXO G - Relação de viveiros de produção de mudas de espécies nativas no Estado de São Paulo.

\begin{tabular}{|c|c|c|c|c|c|c|c|}
\hline Cod. & Nome do viv. & Instituiçao resp. & Municipio & Região & Responsavel & Fone & E-mail \\
\hline 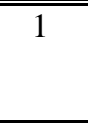 & \multicolumn{2}{|l|}{ Viveiro Floresce Brasil } & Araçatuba & 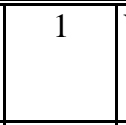 & Valdomiro Ribeiro & $\begin{array}{l}(18) 9786- \\
9163 / 9704- \\
2157 \\
\end{array}$ & www.florescebrasil.com.br \\
\hline 2 & \multicolumn{2}{|c|}{ Secretaria do Meio Ambiente - I.F. } & Araraquara & 3 & $\begin{array}{l}\text { Honório Carlos } \\
\text { Fachin }\end{array}$ & $16-236-5656$ & \\
\hline 3 & $\begin{array}{l}\text { Grupo Virgulino de } \\
\text { Oliveira }\end{array}$ & \begin{tabular}{|l|} 
Usina Unidade de \\
Catanduva
\end{tabular} & $\begin{array}{l}\text { Ariranha } \\
\text { (Catanduva) }\end{array}$ & 1 & $\begin{array}{l}\text { Eng. Agr. Marco } \\
\text { Antonio }\end{array}$ & \multicolumn{2}{|c|}{$\begin{array}{ll}\text { (17) } 5225-131 & \text { r. } 158\end{array}$} \\
\hline 4 & \multicolumn{2}{|c|}{$\begin{array}{l}\text { FLORA VALE - Associaçao de } \\
\text { Recuperaçao do Médio Paranapanema }\end{array}$} & Assis & 2 & $\begin{array}{l}\text { Claudio A. } \\
\text { Bertolucci }\end{array}$ & $\begin{array}{l}(018) 3322- \\
2996\end{array}$ & floravale@fermanet.com.br \\
\hline 5 & $\begin{array}{l}\text { Floresta Estadual de } \\
\text { Assis }\end{array}$ & Instituto Florestal & Assis & 2 & Osmar & $\begin{array}{l}(018) 3322- \\
5965\end{array}$ & \\
\hline 6 & \multicolumn{2}{|c|}{ Secretaria do Meio Amb iente I.F. } & Assis & 2 & $\begin{array}{l}\text { João Carlos Molina } \\
\text { Max }\end{array}$ & $18-3325-1066$ & \\
\hline 7 & \multicolumn{2}{|c|}{ Prefeitura Municipal de Avaí } & Avaí & 1 & $\begin{array}{l}\text { Eng }^{\mathrm{a}} \text { Agr }^{\mathrm{a}} \text { Renata } \\
\text { Oliveira da Silva }\end{array}$ & 14-247-1249 & pmavai@uol.com.br \\
\hline 8 & $\begin{array}{l}\text { Floresta Estadual de } \\
\text { Avaré }\end{array}$ & Instituto Florestal & Avaré & 2 & Hideyo Aoki & $14-3722-0290$ & \\
\hline 9 & \multicolumn{2}{|c|}{ Secretaria do Meio Ambiente I.F. } & Batatais & 3 & Zanata & $16-3662-6327$ & \\
\hline 10 & $\begin{array}{l}\text { Viveiro de Mudas } \\
\text { Brasil }\end{array}$ & & Bauru & 1 & Carlos Alexandre & $\begin{array}{l}(014) 255- \\
1165\end{array}$ & \\
\hline 11 & ACIFLORA & & Bauru & 1 & $\begin{array}{l}\text { Antonio Edson Vido } \\
\text { (Coordenador } \\
\text { técnico) }\end{array}$ & $\begin{array}{l}(014) 230- \\
5975\end{array}$ & aciflora@terra.com.br \\
\hline 12 & $\begin{array}{l}\text { Estação Experimental } \\
\text { de Bauru }\end{array}$ & $\mid \begin{array}{l}\text { Secretaria do Meio } \\
\text { Ambiente I.F. }\end{array}$ & Bauru & 1 & José Carlos & 14-230-1899 & elifbauru@hotmail.com \\
\hline
\end{tabular}

Nota - Relação de viveiros de produção de mudas florestais - Banco de dados do Projeto Matrizes, disponível no site do LERF-ESALQ/USP: http://www.lerf.esalq.usp.br

Legenda: Região 1 - Noroeste; Região 2 - Sudoeste; Região 3-Centro; Região 4- Sudeste; Região 5- Litoral Norte, Região 6 - Litoral Sul. Tabela IBt/SMA - dados não divulgados pelo Instituto de Botânica (Barbosa \& Martins, 2003). 
ANEXO G - Relação de viveiros de produção de mudas de espécies nativas no Estado de São Paulo.

\begin{tabular}{|c|c|c|c|c|c|c|c|}
\hline Cod. & Nome do viv. & Instituiçao resp. & Municipio & Região & Responsavel & Fone & E-mail \\
\hline 13 & \multicolumn{2}{|c|}{$\begin{array}{l}\text { Viveiro Regional de Mudas Nativas - } \\
\text { Instituto Ambiental Vidágua }\end{array}$} & Bauru & 1 & $\begin{array}{l}\text { Biol. Ivan Alexandre } \\
\text { Ferrazoli e Eng. } \\
\text { David Geraldo } \\
\text { Pompei }\end{array}$ & $14-3281.2633$ & contato@vidagua.org.br \\
\hline 14 & \multicolumn{2}{|c|}{ Secretaria do Meio Ambiente I.F. } & Bebedouro & 1 & \begin{tabular}{|l|} 
Paulo Roberto \\
Ferreira da Rosa \\
\end{tabular} & $17-3342-2890$ & \\
\hline 15 & $\begin{array}{l}\text { Estação Experimental } \\
\text { de Bento Quirino }\end{array}$ & $\begin{array}{l}\text { Secretaria do Meio } \\
\text { Ambiente I.F. }\end{array}$ & \begin{tabular}{|l|} 
Bento Quirino \\
\end{tabular} & 3 & Euripdes & $16-684-1352$ & \\
\hline 16 & \multicolumn{2}{|c|}{$\begin{array}{l}\text { Viveiro de Mudas Riviera de São } \\
\text { Lourenço }\end{array}$} & Bertioga & 5 & Zezinho & $\begin{array}{l}(013) 3316- \\
8535\end{array}$ & \\
\hline 17 & \multicolumn{2}{|c|}{$\begin{array}{l}\text { NASCENTES -Associação para a } \\
\text { Recuperação e Preservação dos Recursos } \\
\text { Hídricos }\end{array}$} & Botucatu & 3 & $\begin{array}{l}\text { João Batista de } \\
\text { Oliveira }\end{array}$ & (14) 68226391 & \\
\hline 18 & \multicolumn{2}{|c|}{$\begin{array}{l}\text { ECOAR - Instituto Ecoar para a } \\
\text { Cidadania (ONG- Reposiçao) }\end{array}$} & Buri & 3 & $\begin{array}{l}\text { Eng. Flor. Paulo } \\
\text { Henrique M. e } \\
\text { Carneiro } \\
\end{array}$ & \multicolumn{2}{|c|}{ (015) 546-1331// (011) 3871-0370// 38710701} \\
\hline 19 & MECA-ONG & & Cajati & 6 & $\begin{array}{l}\text { Rildo Belarmino } \\
\text { (Biólogo-viveirista) }\end{array}$ & $\begin{array}{l}(13) 6821 \\
7860 \\
\end{array}$ & belarmino@matriz.com.br \\
\hline 20 & \multicolumn{2}{|c|}{ Viveiro de Mudas Alameda } & Campinas & 3 & $\begin{array}{l}\text { Marta Chaim Pinto } \\
\text { Portas - Engenheira } \\
\text { Agronôma }\end{array}$ & $\begin{array}{l}(019) 3207- \\
4021 / 3760- \\
5013\end{array}$ & alameda@mpc.cpm.br \\
\hline 21 & ARBORETO & Tabela IBt/SMA & Campinas & 3 & & & \\
\hline 22 & $\begin{array}{l}\text { Viveiro de mudas } \\
\text { Nativas Mata } \\
\end{array}$ & Tabela IBt/SMA & Campinas & 3 & & & \\
\hline 23 & \multicolumn{2}{|c|}{ Meio Ambiente Viveiro Florestal } & $\begin{array}{l}\text { Campo Limpo } \\
\text { Paulista }\end{array}$ & 4 & Mônica & & meioambiente.@uol.com.br \\
\hline
\end{tabular}

Nota - Relação de viveiros de produção de mudas florestais - Banco de dados do Projeto Matrizes, disponível no site do LERF-ESALQ/USP: http://www.lerf.esalq.usp.br

Legenda: Região 1 - Noroeste; Região 2 - Sudoeste; Região 3-Centro; Região 4- Sudeste; Região 5- Litoral Norte, Região 6 - Litoral Sul. Tabela IBt/SMA - dados não divulgados pelo Instituto de Botânica (Barbosa \& Martins, 2003). 
ANEXO G - Relação de viveiros de produção de mudas de espécies nativas no Estado de São Paulo.

\begin{tabular}{|c|c|c|c|c|c|c|c|}
\hline Cod. & Nome do viv. & Instituiçao resp. & Municipio & Região & Responsavel & Fone & E-mail \\
\hline 24 & $\begin{array}{l}\text { Parque Estadual de } \\
\text { Campos do jordão }\end{array}$ & Instituto Florestal & Campos do Jordão & 4 & \begin{tabular}{|l} 
Marco Antonio Pupio \\
Marcondes
\end{tabular} & 12-263-1977 & \\
\hline 25 & \multicolumn{2}{|c|}{$\begin{array}{l}\text { ECOAR - Viveiro Associação de } \\
\text { Reposiçao Florestal }\end{array}$} & Capão Bonito & 4 & $\begin{array}{l}\text { Eng. Paulo Cesar } \\
\text { Carneiro }\end{array}$ & $11-3871.0370$ & florestal@ecoar.org.br \\
\hline 26 & \multicolumn{2}{|c|}{$\begin{array}{l}\text { Viveiro Municipal de Capivari - } \\
\text { Prefeitura Municipal }\end{array}$} & Capivari & 3 & $\begin{array}{l}\text { Carlos Alberto } \\
\text { Schincariol }\end{array}$ & $19-3491-2531$ & caschincariol@uol.com.br \\
\hline 27 & $\begin{array}{l}\text { Estação Experimental } \\
\text { de Casa Branca }\end{array}$ & $\begin{array}{l}\text { Secretaria do Meio } \\
\text { Ambiente I.F. }\end{array}$ & Casa Branca & 3 & $\begin{array}{l}\text { Demétrio Vasco de } \\
\text { Toledo Filhos }\end{array}$ & 19-671-1046 & \\
\hline 28 & $\begin{array}{l}\text { Água Limpa - Pró } \\
\text { Flora }\end{array}$ & $\begin{array}{l}\text { Estância Sempre } \\
\text { Verde }\end{array}$ & Cedral & 1 & $\begin{array}{l}\text { Garibaldi Machado } \\
\text { Leopoldino }\end{array}$ & $17-3268-7111$ & garibaldi@unisolo.com.br \\
\hline 29 & Sítio da Painera & Tabela IBt/SMA & Cunha & 4 & & & \\
\hline 30 & $\begin{array}{l}\text { Quilombo } \\
\text { Ivaporanduva }\end{array}$ & Tabela IBt/SMA & Eldorado & 6 & & & \\
\hline 31 & $\begin{array}{l}\text { Quilombo Maria } \\
\text { Rosa }\end{array}$ & Tabela IBt/SMA & Eldorado & 6 & & & \\
\hline 32 & \multicolumn{2}{|c|}{ Fazenda Morada das Nascentes } & Eldorado & 6 & \multicolumn{2}{|c|}{ Cesar Augusto Leite de Oliveira } & \\
\hline 33 & Quilombo Nhunguara & Tabela IBt/SMA & Eldorado & 6 & & & \\
\hline 34 & Viveiro Pau Brasil & & Fernandópolis & 1 & $\begin{array}{l}\text { Eng. Ag. Fabrício } \\
\text { Salloni }\end{array}$ & $\begin{array}{l}(017) 442- \\
5589\end{array}$ & \\
\hline 35 & Verde Vida & Tabela IBt/SMA & Florínea & 2 & & & \\
\hline 36 & \multicolumn{2}{|c|}{$\begin{array}{l}\text { Flora Rio Grande - Associação de } \\
\text { Recuperação Floretal do Vale do Rio } \\
\text { Grande }\end{array}$} & Franca & 3 & Neusa Peixoto & $\begin{array}{l}(016) 3722- \\
0993\end{array}$ & \\
\hline 37 & \multicolumn{2}{|c|}{$\begin{array}{l}\text { Jardim ZOO-BOTANICO Municipal de } \\
\text { Franca }\end{array}$} & Franca & 3 & Célio Berteli & \begin{tabular}{|l}
$(016) 371-$ \\
19001
\end{tabular} & \\
\hline
\end{tabular}

Nota - Relação de viveiros de produção de mudas florestais - Banco de dados do Projeto Matrizes, disponível no site do LERF-ESALQ/USP: http://www.lerf.esalq.usp.br

Legenda: Região 1 - Noroeste; Região 2 - Sudoeste; Região 3-Centro; Região 4- Sudeste; Região 5- Litoral Norte, Região 6 - Litoral Sul. Tabela IBt/SMA - dados não divulgados pelo Instituto de Botânica (Barbosa \& Martins, 2003). 
ANEXO G - Relação de viveiros de produção de mudas de espécies nativas no Estado de São Paulo.

\begin{tabular}{|c|c|c|c|c|c|c|c|}
\hline Cod. & Nome do viv. & Instituiçao resp. & Municipio & Região & Responsavel & Fone & E-mail \\
\hline 38 & \multicolumn{2}{|c|}{ Prefeitura Municipal de Guaratinguetá } & Guaratinguetá & 4 & & 125251902 & julianaloyola@uol.com.br \\
\hline 39 & \multicolumn{2}{|c|}{ Viveiro Fazenda Santa Isabel } & Guariba & 3 & $\begin{array}{l}\text { Paulo de Araujo } \\
\text { Rodrigues }\end{array}$ & $\begin{array}{l}(016) 681- \\
1911\end{array}$ & \\
\hline 40 & \multicolumn{2}{|c|}{$\begin{array}{l}\text { SASIP - Sociedade dos Amigos de } \\
\text { Iporanga }\end{array}$} & Guarujá & 5 & $\begin{array}{l}\text { Ricardo Zuppi - } \\
\text { coordenador meio } \\
\text { ambiente }\end{array}$ & $\begin{array}{l}(013) 3305- \\
1090\end{array}$ & $\begin{array}{l}\text { rzupp@ hotmail.com / } \\
\text { sasipiporanga@uol.com }\end{array}$ \\
\hline 41 & \multicolumn{2}{|c|}{ CAMARÁ Mudas Florestais } & Ibaté & 3 & $\begin{array}{l}\text { Carlos Nogueira } \\
\text { Souza Jr. / José } \\
\text { Carlos Madaschi. } \\
\text { Henrique Lott Perigo } \\
\end{array}$ & $\begin{array}{l}16-243- \\
1668 / / 16-243- \\
1440\end{array}$ & comercial@amudas-camara.com.br \\
\hline 42 & $\begin{array}{l}\text { Viveiro Municipal de } \\
\text { Espécies Nativas de } \\
\text { Ilha Comprida }\end{array}$ & Tabela IBt/SMA & Ilha Comprida & 6 & & & \\
\hline 43 & \multicolumn{2}{|c|}{ FLONA de Ipanema - IBAMA } & Ipero & 3 & $\begin{array}{l}\text { Jose Aelcidio Duarte } \\
\text { Vieira - analista } \\
\text { ambiental }\end{array}$ & $\begin{array}{l}(015) 266- \\
9098\end{array}$ & flonadipanema@ig.com.br \\
\hline 44 & $\begin{array}{l}\text { Viveiro Municipal de } \\
\text { Mudas Florestais - } \\
\text { Prefeitura Municipal }\end{array}$ & & Iracemápolis & 3 & $\begin{array}{l}\text { Eng }{ }^{\circ} \text { Agr. Reynaldo } \\
\text { Boschiero }\end{array}$ & $19-3456-2066$ & ca.iracemapolis@cati.sp.gov.br \\
\hline 45 & $\begin{array}{l}\text { Núcleo de Produção } \\
\text { de Mudas - CATI }\end{array}$ & Tabela IBt/SMA & Itaberá & 3 & & & \\
\hline 46 & \multicolumn{2}{|c|}{ Secretaria do Meio Ambiente I.F. } & Itapetininga & 3 & Antonio Cecilio Dias & $15-271-3866$ & \\
\hline 47 & \multicolumn{2}{|c|}{ Secretaria do Meio Ambiente I.F. } & Itapetininga & 3 & Claudio Monteiro & 14-271-3866 & \\
\hline 48 & $\begin{array}{l}\text { Viveiro da Fazenda } \\
\text { Águas Claras }\end{array}$ & $\begin{array}{l}\text { Fazenda Águas } \\
\text { Claras/ Fazenda } \\
\text { Ambiental }\end{array}$ & Itapira & 4 & Eduardo Aranha & 1938923475 & $\begin{array}{l}\text { fazendaambiental@fazendaambiental } \\
\text {.org.br }\end{array}$ \\
\hline
\end{tabular}

Nota - Relação de viveiros de produção de mudas florestais - Banco de dados do Projeto Matrizes, disponível no site do LERF-ESALQ/USP: http://www.lerf.esalq.usp.br

Legenda: Região 1 - Noroeste; Região 2 - Sudoeste; Região 3-Centro; Região 4- Sudeste; Região 5- Litoral Norte, Região 6 - Litoral Sul. Tabela IBt/SMA - dados não divulgados pelo Instituto de Botânica (Barbosa \& Martins, 2003). 
ANEXO G - Relação de viveiros de produção de mudas de espécies nativas no Estado de São Paulo.

\begin{tabular}{|c|c|c|c|c|c|c|c|}
\hline Cod. & Nome do viv. & Instituiçao resp. & Municipio & Região & Responsavel & Fone & E-mail \\
\hline 49 & $\begin{array}{l}\text { Mata Atlântica } \\
\text { Viveiro Florestal }\end{array}$ & Tabela IBt/SMA & Itatiba & 4 & & & \\
\hline 50 & \multicolumn{2}{|c|}{$\begin{array}{l}\text { Viveiro de Mudas -Horto Florestal } \\
\text { Jaboticabal/UNESP }\end{array}$} & Jaboticabal & 3 & $\begin{array}{l}\text { Rinaldo César de } \\
\text { Paula/ Prof. Kátia }\end{array}$ & $\begin{array}{l}(016) 3209- \\
2668\end{array}$ & \\
\hline 51 & \multicolumn{2}{|c|}{ Sítio Alaor - VCP Florestal AS } & Jacareí & 4 & Eng. João Iijima & \multicolumn{2}{|c|}{$12-3951-2374 / / 12-3951-5177$} \\
\hline 52 & \multicolumn{2}{|c|}{$\begin{array}{l}\text { FLORA CANTAREIRA - Associação de } \\
\text { Recuperação Florestal das Bacias dos } \\
\text { Rios Jaguari, Atibais, Camanducaia e } \\
\text { Sistema Cantareira }\end{array}$} & Jaguariuna & 3 & $\begin{array}{l}\text { Carlos Zima Júnior - } \\
\text { gerente geral }\end{array}$ & $\begin{array}{l}(019) 3893- \\
3468 /(019) \\
3893-2961\end{array}$ & floracantareira@uol.com.br \\
\hline 53 & \multicolumn{2}{|c|}{ Secretaria do Meio Ambiente I.F. } & Jaú & 3 & $\begin{array}{l}\text { Omar Jorge Dio } \\
\text { Junior }\end{array}$ & $14-6231-1008$ & \\
\hline 54 & CEETEPS & & Jaú & 3 & Paulo Camargo Abdo & \begin{tabular}{|l|}
$14-623-1170 / /$ \\
$14-623-1190$
\end{tabular} & etae.jau@netsite.com.br \\
\hline 55 & Trópica Flora & & \begin{tabular}{|l} 
Jundiaí \\
\end{tabular} & 4 & & \begin{tabular}{|l}
$(019) 543-$ \\
6611 \\
\end{tabular} & \\
\hline 56 & $\begin{array}{l}\text { Viveiro de Produção } \\
\text { de Mudas da CESP }\end{array}$ & Tabela IBt/SMA & Jupiá & 1 & & & \\
\hline 57 & \multicolumn{2}{|c|}{ BIOVERDE - Árvores do Brasil } & Limeira & 3 & Marcos D. Bernardo & $19-3451.1840$ & arvoresdobrasil@bioverde.com.br \\
\hline 58 & \multicolumn{2}{|c|}{ Dierberger Plantas Ltda. } & Limeira & 3 & $\begin{array}{l}\text { Eng. Salete della } \\
\text { Coletta }\end{array}$ & \begin{tabular}{|l|}
$19-3451.1221$ \\
$/ 19-$ \\
3451.5103 \\
\end{tabular} & fazendacitra@li meira.com.br \\
\hline 59 & \multicolumn{2}{|c|}{$\begin{array}{l}\text { Viveiro Horto Florestal de Limeira - } \\
\text { Secretaria da Agricultura e Meio } \\
\text { Ambiente }\end{array}$} & Limeira & 3 & Marcelo Fáveri Jorge & $19-3442-2775$ & faverijorge@uol.com \\
\hline
\end{tabular}

Nota - Relação de viveiros de produção de mudas florestais - Banco de dados do Projeto Matrizes, disponível no site do LERF-ESALQ/USP: http://www.lerf.esalq.usp.br

Legenda: Região 1 - Noroeste; Região 2 -Sudoeste; Região 3-Centro; Região 4- Sudeste; Região 5- Litoral Norte, Região 6 - Litoral Sul. Tabela IBt/SMA - dados não divulgados pelo Instituto de Botânica (Barbosa \& Martins, 2003). 
ANEXO G - Relação de viveiros de produção de mudas de espécies nativas no Estado de São Paulo.

\begin{tabular}{|c|c|c|c|c|c|c|c|}
\hline Cod. & Nome do viv. & Instituiçao resp. & Municipio & Região & Responsavel & Fone & E-mail \\
\hline 60 & $\begin{array}{l}\text { Flora Paraíba de } \\
\text { Recuperação } \\
\text { Florestal do Vale do } \\
\text { Paraíba }\end{array}$ & Tabela IBt/SMA & Lorena & 4 & & $\begin{array}{l}(012) 552- \\
3922\end{array}$ & \\
\hline 61 & \multicolumn{2}{|c|}{ Viveiro de Pesquisa - VCP Florestal AS } & Luiz Antonio & 3 & & $16-3986-9127$ & \\
\hline 62 & Flora Paulista & \begin{tabular}{|l} 
Associaçao \\
Paulista \\
Recuperaçao e \\
Preservaçao \\
Ecologia \\
\end{tabular} & Marília & 2 & $\begin{array}{l}\text { Eng. Ricardo Luiz } \\
\text { Canova }\end{array}$ & $14-423.3463$ & flora@ coopemar.com.br \\
\hline 63 & $\begin{array}{l}\text { Núcleo de Produçao } \\
\text { de Mudas - } \\
\text { Departamento de } \\
\text { Sementes, Mudas e } \\
\text { Matrizes (DSMM) - } \\
\text { CATI. }\end{array}$ & CATI & Marília & 2 & $\begin{array}{l}\text { Eng }^{\circ} \text { Agr. }^{\circ} \text { Cláudio } \\
\text { Hagime Funai, Crea } \\
\text { 187345/D }\end{array}$ & $14-433-4188$ & catimudas@uol.com.br \\
\hline $\begin{array}{l}64 \\
65\end{array}$ & $\begin{array}{l}\text { Flora Wolpert } \\
\text { Viveiro de Mudas da } \\
\text { Municipal de Miracatu }\end{array}$ & Prefeitura & $\begin{array}{l}\text { Miracatu } \\
\text { Miracatu }\end{array}$ & $\begin{array}{l}6 \\
6\end{array}$ & $\begin{array}{l}\text { Fabio / Marlene } \\
\text { Evaristo de Castro } \\
\text { Reitz (Diretor do } \\
\text { Depto.) }\end{array}$ & $\begin{array}{l}(13) 3847- \\
3733 \text { (Viveiro) } \\
/(13) 6847- \\
1811 \\
\text { (Prefeitura) } \\
\end{array}$ & $\begin{array}{l}\text { jwolpert@matrix.com.br } \\
\text { agriculturamtu@hotmix.com.br }\end{array}$ \\
\hline 66 & $\begin{array}{l}\text { Viveiro Pé de } \\
\text { Galinha- } \\
\text { Assentamento São } \\
\text { Bento }\end{array}$ & Tabela IBt/SMA & $\begin{array}{l}\text { Mirante do } \\
\text { Paranapanema }\end{array}$ & 2 & & & \\
\hline
\end{tabular}

Nota - Relação de viveiros de produção de mudas florestais - Banco de dados do Projeto Matrizes, disponível no site do LERF-ESALQ/USP: http://www.lerf.esalq.usp.br

Legenda: Região 1 - Noroeste; Região 2 - Sudoeste; Região 3-Centro; Região 4- Sudeste; Região 5- Litoral Norte, Região 6 - Litoral Sul. Tabela IBt/SMA - dados não divulgados pelo Instituto de Botânica (Barbosa \& Martins, 2003). 
ANEXO G - Relação de viveiros de produção de mudas de espécies nativas no Estado de São Paulo.

\begin{tabular}{|c|c|c|c|c|c|c|c|}
\hline Cod. & Nome do viv. & Instituiçao resp. & Municipio & Região & Responsavel & Fone & E-mail \\
\hline 67 & $\begin{array}{l}\text { Instituto Florestal - E } \\
\text { de Mogi-Mirim }\end{array}$ & stação Experimental & Mogi - Mirim & 3 & $\begin{array}{l}\text { Paulo Ricardo Brum } \\
\text { Pereira }\end{array}$ & $19-3862-2787$ & \\
\hline 68 & Viveiro Florestal da I & nternational Paper & Mogi-Guaçu & 3 & Claudia Iannelli & $3831-4769$ & claudiaiannelli@ipaperbr.com \\
\hline 69 & $\begin{array}{l}\text { Estação Experimental } \\
\text { de Mogi-Guaçu }\end{array}$ & $\begin{array}{l}\text { Instituto Florestal } \\
\text {-SMA }\end{array}$ & Mogi-Guaçu & 3 & $\begin{array}{l}\text { Eduardo Amaral } \\
\text { Batista }\end{array}$ & 19-268-9049 & \\
\hline 70 & $\begin{array}{l}\text { Giop lanta Comércio } \\
\text { e Representação } \\
\text { Agrícola Ltda }\end{array}$ & $\begin{array}{l}\text { Casa da } \\
\text { Agricultura }\end{array}$ & Monte Mor & 3 & José Ricardo Giogetti & $19-3879-2488$ & gioplant@interall.com.br \\
\hline 71 & Pró-Flora & & Onda Verde & 1 & & $\begin{array}{l}(017) 225- \\
4100\end{array}$ & $\begin{array}{l}\text { proflora@ proflora.com.br } \\
(017) 268-1148\end{array}$ \\
\hline 72 & $\begin{array}{l}\text { FLORA VALE - } \\
\text { Associaçao de } \\
\text { Recuperaçao do } \\
\text { Médio Paranapanema }\end{array}$ & Tabela IBt/SMA & Ourinhos & 2 & & $\begin{array}{l}(014) 3322- \\
7812\end{array}$ & \\
\hline 73 & Casa da Agricultura & $\begin{array}{l}\text { Casa da } \\
\text { Agricultura }\end{array}$ & Ouro Verde & 2 & $\begin{array}{l}\text { Eng. Agr. Cláudio } \\
\text { Mura }\end{array}$ & $\begin{array}{l}18) 5872 \\
1157 \\
\end{array}$ & \\
\hline 74 & $\begin{array}{l}\text { Viveiro Municipal de } \\
\text { Palmital }\end{array}$ & Tabela IBt/SMA & Palmital & 2 & & & \\
\hline 75 & \multicolumn{2}{|c|}{$\begin{array}{l}\text { Instituto Florestal - Estação Experimental } \\
\text { de Paraguaçu Paulista }\end{array}$} & Paraguaçu Paulista & 2 & Helder & 18-361-1909 & \\
\hline 76 & $\begin{array}{l}\text { Viveiro de Produção } \\
\text { de Mudas da CESP - } \\
\text { Paraibuna }\end{array}$ & \begin{tabular}{|l|} 
CESP - Cia de \\
Energia de São \\
Paulo
\end{tabular} & Paraibuna & 4 & Téc. Marcelo Cruz & $12-3974-0491$ & mgfpb@ig.com.br \\
\hline 77 & $\begin{array}{l}\text { SAGA - Suporte } \\
\text { Agro Ambinetal } \\
\text { Ltda. }\end{array}$ & Tabela IBt/SMA & Paraibuna & 4 & & & \\
\hline
\end{tabular}

Nota - Relação de viveiros de produção de mudas florestais - Banco de dados do Projeto Matrizes, disponível no site do LERF-ESALQ/USP: http://www.lerf.esalq.usp.br

Legenda: Região 1 - Noroeste; Região 2 - Sudoeste; Região 3-Centro; Região 4- Sudeste; Região 5- Litoral Norte, Região 6 - Litoral Sul. Tabela IBt/SMA - dados não divulgados pelo Instituto de Botânica (Barbosa \& Martins, 2003). 
ANEXO G - Relação de viveiros de produção de mudas de espécies nativas no Estado de São Paulo.

\begin{tabular}{|c|c|c|c|c|c|c|c|}
\hline Cod. & Nome do viv. & Instituiçao resp. & Municipio & Região & Responsavel & Fone & E-mail \\
\hline 78 & \multicolumn{2}{|c|}{$\begin{array}{l}\text { Instituto Florestal - Floresta Estadual de } \\
\text { Paranapanema }\end{array}$} & Paranapanema & 3 & Hideyo Aoki & $14-3732-0290$ & onglora@uol.com.br \\
\hline 79 & \multicolumn{2}{|c|}{$\begin{array}{l}\text { Núcleo de Produçao de Mudas de } \\
\text { Pederneiras - CATI - Sementes e Mudas } \\
\text { DSMM }\end{array}$} & Pederneiras & 1 & $\begin{array}{l}\text { Wilson Roberto } \\
\text { Marques Salles }\end{array}$ & $14-252.1364$ & npmpe@bironet.com.br \\
\hline 80 & \multicolumn{2}{|c|}{$\begin{array}{l}\text { Beta Empreendimentos Agroflorestais } \\
\text { Ltda }\end{array}$} & Penápolis & 1 & Roberta Freitas & $\begin{array}{l}(018) 652- \\
1954\end{array}$ & beta.bef@terra.com.br \\
\hline 81 & $\begin{array}{l}\text { Flora Tietê - } \\
\text { Associação de } \\
\text { Recuperação do } \\
\text { Médio Tietê }\end{array}$ & \begin{tabular}{|l|} 
FLORA TIETÊ - \\
Associaçao de \\
Recuperaçao \\
Florestal do Médio \\
Tietê
\end{tabular} & Penápolis & 1 & $\begin{array}{l}\text { Eng. Fernando } \\
\text { Alberto Buzetto }\end{array}$ & $\begin{array}{l}18-652.2623 / / \\
18-652.2948\end{array}$ & fl.tiete@ terra.com.br \\
\hline 82 & $\begin{array}{l}\text { Instituto Florestal - } \\
\text { Parque Estadual de } \\
\text { Jurupará }\end{array}$ & Tabela IBt/SMA & Piedade & 4 & & & \\
\hline 83 & \multicolumn{2}{|c|}{ ECOAR - Viveiro Florestal } & Pilar do Sul & 4 & $\begin{array}{l}\text { Eng. João Carlos } \\
\text { Seiki Nagamura } \\
\end{array}$ & $11-3871.0370$ & florestal@ecoar.org.br \\
\hline 84 & \multicolumn{2}{|c|}{$\begin{array}{l}\text { Eucalyptus S.S Viveiros de Mudas e } \\
\text { Meio Ambiente }\end{array}$} & Pindamonhangaba & 4 & Andréia & $\begin{array}{l}(012) 242- \\
7773\end{array}$ & vivcmud@uol.com.br \\
\hline 85 & $\begin{array}{l}\text { Viveiro Florestal de } \\
\text { Pindamonhangaba }\end{array}$ & Instituto Florestal & Pindamonhangaba & 4 & $\begin{array}{l}\text { Laercio Cortez } \\
\text { Toledo } \\
\end{array}$ & $12-242-3910$ & \\
\hline 86 & \multicolumn{2}{|c|}{$\begin{array}{l}\text { Tmudas - Antonio Marmo da Silva Alves } \\
\text { ME }\end{array}$} & Pindamonhangaba & 4 & $\begin{array}{l}\text { Washinton Luiz } \\
\text { Agueda }\end{array}$ & \multicolumn{2}{|c|}{$12-242-2071 / / 12-9707-1710$} \\
\hline 87 & \multicolumn{2}{|c|}{$\begin{array}{l}\text { FLORESPI-Associaçao de Reposiçao } \\
\text { Florestal Bacia do Rio Piracicaba }\end{array}$} & Piracicaba & 3 & $\begin{array}{l}\text { Eng. Ricardo O. L. } \\
\text { Schmidt }\end{array}$ & \begin{tabular}{|l|}
$19-3434-2328$ \\
$/ 19-3433-$ \\
1614 \\
\end{tabular} & florespi@uol.com.br \\
\hline
\end{tabular}

Nota - Relação de viveiros de produção de mudas florestais - Banco de dados do Projeto Matrizes, disponível no site do LERF-ESALQ/USP: http://www.lerf.esalq.usp.br

Legenda: Região 1 - Noroeste; Região 2 - Sudoeste; Região 3-Centro; Região 4- Sudeste; Região 5- Litoral Norte, Região 6 - Litoral Sul. Tabela IBt/SMA - dados não divulgados pelo Instituto de Botânica (Barbosa \& Martins, 2003). 
ANEXO G - Relação de viveiros de produção de mudas de espécies nativas no Estado de São Paulo.

\begin{tabular}{|c|c|c|c|c|c|c|c|}
\hline Cod. & Nome do viv. & Instituiçao resp. & Municipio & Região & Responsavel & Fone & E-mail \\
\hline 88 & \multicolumn{2}{|c|}{$\begin{array}{l}\text { Horto de Tupi - Viveiro Municipal de } \\
\text { Piracicaba }\end{array}$} & Piracicaba & 3 & $\begin{array}{l}\text { Reinaldo C. } \\
\text { Romanelli }\end{array}$ & \multicolumn{2}{|c|}{ 19-438-7116 // 19-438-7200 } \\
\hline 89 & Viveiro Flora Nativa & Tabela IBt/SMA & Piracicaba & 3 & & & \\
\hline 90 & \multicolumn{2}{|c|}{$\begin{array}{l}\text { Viveiro do Instituto de Pesquisas e } \\
\text { Estudos Florestais - IPEF (ESALQ/USP) }\end{array}$} & Piracicaba & 3 & & & \\
\hline 91 & $\begin{array}{l}\text { Viveiro Florestal - } \\
\text { ECOAR }\end{array}$ & ECOAR & Porto Feliz & 3 & \multicolumn{2}{|c|}{$\begin{array}{l}\text { Joâo Carlos Seiki Nagamura } \\
\text { (Secretário execurivo) }\end{array}$} & ecoarflorestal@ecoar.org.br \\
\hline 92 & \multicolumn{2}{|c|}{$\begin{array}{l}\text { Núcleo de Produçao de Mudas de } \\
\text { Presidente Prudente - DSMM/CATI }\end{array}$} & $\begin{array}{l}\text { Presidente } \\
\text { Prudente }\end{array}$ & 2 & $\begin{array}{l}\text { Eng. Renato de } \\
\text { Oliveira Lima }\end{array}$ & $18-222-4177$ & npmpp@ stetnet.com.br \\
\hline 93 & \multicolumn{2}{|c|}{$\begin{array}{l}\text { PONTAL FLORA- Associação } \\
\text { Recuperação Florestal Pontal } \\
\text { Paranapanema }\end{array}$} & $\begin{array}{l}\text { Presidente } \\
\text { Venceslau }\end{array}$ & 2 & $\begin{array}{l}\text { Heder Carlos } \\
\text { Rodrigues de Mello }\end{array}$ & \begin{tabular}{|l|}
$18-271-3633 / /$ \\
$18-271-8085$
\end{tabular} & pontalflora@uol.com.br \\
\hline 94 & \multicolumn{2}{|c|}{ Viveiro de Promissão -AES Tietê S.A } & Promissão & 1 & $\begin{array}{l}\text { Eng } \hat{\mathrm{A}}^{\circ} \operatorname{Agr} \hat{\mathrm{A}}^{\circ} \text { Jos } \tilde{\mathrm{A}} \subset \\
\text { Luiz do Amaral } \\
\text { Simionato }\end{array}$ & $14-3543-9926$ & mudas.aestiete@aes.com \\
\hline 95 & AES Tietê S/A & & Promissão & 1 & $\begin{array}{l}\text { Donizete Barbosa de } \\
\text { Oliveira - analista de } \\
\text { meio ambiente }\end{array}$ & $\begin{array}{l}(014) 3543- \\
9928\end{array}$ & donizete.oliveira@aes.com \\
\hline 96 & $\begin{array}{l}\text { Viveiro Municipal de } \\
\text { Ribeirão Preto }\end{array}$ & \begin{tabular}{|l|} 
Prefeitura \\
Municipal de \\
Ribeirão Preto \\
\end{tabular} & Ribeirão Preto & 3 & $\begin{array}{l}\text { Eng }^{\mathbf{0}} \text { Florestal Paulo } \\
\text { Melo }\end{array}$ & \begin{tabular}{|l|}
$16-637-6198 / /$ \\
$16-637-3341$
\end{tabular} & $\begin{array}{l}\text { horto.seplam@ ribeiraopreto.sp.gov.b } \\
\mathrm{r}\end{array}$ \\
\hline 97 & \multicolumn{2}{|c|}{$\begin{array}{l}\text { Tecplant-Comércio Agricola e Serviços } \\
\text { Ltda }\end{array}$} & Rio Claro & 3 & $\begin{array}{l}\begin{array}{l}\text { Paulo Ribeiro Anania } \\
\text { - sócio/gerente }\end{array} \\
\end{array}$ & $\begin{array}{l}(019) 533- \\
7070\end{array}$ & $\begin{array}{l}\text { pfanania@ @ecplant.com.brl } \\
\text { www.tecplant.com.br }\end{array}$ \\
\hline 98 & Schmidt Mudas & & Rio Claro & 3 & $\begin{array}{l}\text { Eng }^{\circ} \text { Agr }^{\circ} \text { Helio } \\
\text { Augusto Povoas } \\
\text { Schmidt }\end{array}$ & 19-9786-2000 & schmidthap@linkway.com.br \\
\hline
\end{tabular}


ANEXO G - Relação de viveiros de produção de mudas de espécies nativas no Estado de São Paulo.

\begin{tabular}{|c|c|c|c|c|c|c|c|}
\hline Cod. & Nome do viv. & Instituiçao resp. & Municipio & Região & Responsavel & Fone & E-mail \\
\hline 99 & $\begin{array}{l}\text { Viveiro de Produção } \\
\text { de Mudas da CESP }\end{array}$ & Tabela IBt/SMA & Rosana & 2 & & & \\
\hline 100 & $\begin{array}{l}\text { Viveiro de Mudas } \\
\text { Municipal }\end{array}$ & $\begin{array}{l}\text { Prefeitura } \\
\text { Municipal }\end{array}$ & $\begin{array}{l}\text { Santa Cruz da } \\
\text { Conceiçao }\end{array}$ & 3 & $\begin{array}{l}\text { Eng. Agr }{ }^{\circ} \text { Ronaldo } \\
\text { Tavares de Araujo }\end{array}$ & $\begin{array}{l}\text { 19-567-1320 } \\
\text { (Pref. Mun.) } \\
19-567-1235 \\
\text { (Cati) }\end{array}$ & $\begin{array}{l}\text { ca.santacruzconceicao@cati.sp.gov.b } \\
\mathrm{r}\end{array}$ \\
\hline 101 & Fazenda Cara Preta - & VCP Florestal AS & $\begin{array}{l}\text { Santa Rita do } \\
\text { Passa Quatro }\end{array}$ & 3 & $\begin{array}{l}\text { Rogério } \\
\text { Przybyszewski }\end{array}$ & $19-3592-9722$ & rogeriop@vcp.com.br \\
\hline 102 & $\begin{array}{l}\text { Estaçao Experimental } \\
\text { Passa Quatro-Institutc }\end{array}$ & $\begin{array}{l}\text { de Santa Rita do } \\
\text { o Florestal }\end{array}$ & \begin{tabular}{|l} 
Santa Rita do \\
Passa Quatro
\end{tabular} & 3 & Everton José Ribeiro & $19-582-1807$ & \\
\hline 103 & $\begin{array}{l}\text { Nucleo de Produção } \\
\text { de Mudas - CATI }\end{array}$ & Tabela IBt/SMA & \begin{tabular}{|l|} 
São Bento do \\
Sapucaí
\end{tabular} & 4 & & & \\
\hline 104 & \multicolumn{2}{|c|}{$\begin{array}{l}\text { CIPREJIM - Consórcio Intermunicipal de } \\
\text { Preservaçao da Bacia do Rio Jaguari- } \\
\text { Mirim - Ciprejim }\end{array}$} & $\begin{array}{l}\text { São João da Boa } \\
\text { Vista }\end{array}$ & 4 & $\begin{array}{l}\text { Willian Feldberg } \\
\text { Karp }\end{array}$ & \begin{tabular}{|l|}
$19-634.1020 / /$ \\
$19-631.5083$
\end{tabular} & engenharia@saojoao.sp.gov.br \\
\hline 105 & \multicolumn{2}{|c|}{ Secretaria do Meio Ambiente I.F. } & $\begin{array}{l}\text { São José do Rio } \\
\text { Preto } \\
\end{array}$ & 1 & & $17-233-6404$ & \\
\hline 106 & \multicolumn{2}{|c|}{$\begin{array}{l}\text { VITAL FLORA - Associaçao } \\
\text { Reflorestamento Noroeste Est. S.P. }\end{array}$} & $\begin{array}{l}\text { São José do Rio } \\
\text { Preto }\end{array}$ & 1 & $\begin{array}{l}\text { Luis Eduardo Fil de } \\
\text { Almeida }\end{array}$ & $17-224-3959$ & vitalflora@ vitalflora.org.br \\
\hline 107 & $\begin{array}{l}\text { Fazenda Nossa } \\
\text { Senhora Aparecida }\end{array}$ & Tabela IBt/SMA & \begin{tabular}{|l|} 
São José dos \\
Campos \\
\end{tabular} & 4 & & & \\
\hline 108 & $\begin{array}{l}\text { Empresa WMT } \\
\text { Ambiental }\end{array}$ & Tabela IBt/SMA & $\begin{array}{l}\text { São José dos } \\
\text { Campos }\end{array}$ & 4 & Marcelo Manara & & \\
\hline 109 & Fundação Florestal & & São Paulo & 4 & Luiz & $\begin{array}{l}(011) 5517- \\
6146\end{array}$ & \\
\hline
\end{tabular}

Nota - Relação de viveiros de produção de mudas florestais - Banco de dados do Projeto Matrizes, disponível no site do LERF-ESALQ/USP: http://www.lerf.esalq.usp.br

Legenda: Região 1 - Noroeste; Região 2 - Sudoeste; Região 3-Centro; Região 4- Sudeste; Região 5- Litoral Norte, Região 6 - Litoral Sul. Tabela IBt/SMA - dados não divulgados pelo Instituto de Botânica (Barbosa \& Martins, 2003). 
ANEXO G - Relação de viveiros de produção de mudas de espécies nativas no Estado de São Paulo.

\begin{tabular}{|c|c|c|c|c|c|c|c|}
\hline Cod. & Nome do viv. & Instituiçao resp. & Municipio & Região & Responsavel & Fone & E-mail \\
\hline 110 & $\begin{array}{l}\text { Parque Estadual de } \\
\text { Jurupará }\end{array}$ & $\begin{array}{l}\text { Secretaria do Meio } \\
\text { Ambiente I.F. }\end{array}$ & São Paulo & 4 & Paulo Pimenta & \multicolumn{2}{|c|}{$11-6231-8555$ ramal 319} \\
\hline 111 & $\begin{array}{l}\text { Viveiro Florestal da } \\
\text { Capital }\end{array}$ & $\begin{array}{l}\text { Secretaria do Meio } \\
\text { Ambiente I.F. }\end{array}$ & São Paulo & 4 & $\begin{array}{l}\text { Eng. Agr }{ }^{\circ} \text { Guenji } \\
\text { Yamazoe }\end{array}$ & \multicolumn{2}{|c|}{$11-6231-8555$ ramal 295} \\
\hline 112 & Viveiro Municipal & \begin{tabular}{|l|} 
Secretaria de \\
Agricultura e \\
Recursos Hídricos \\
\end{tabular} & São Pedro & 3 & Alex Salvany Felinto & & \\
\hline 113 & $\begin{array}{l}\text { SOBRASIL - Projetos } \\
\text { florestal }\end{array}$ & s de recuperação & São Pedro & 3 & Paulo Marques & 1934831275 & sobrasil@linksat.com.br \\
\hline 114 & Viveiro Flora Salvia & & São Sebastião & 5 & Vera Flamino & $\begin{array}{l}(12) 9714 \\
0539\end{array}$ & \\
\hline 115 & $\begin{array}{l}\text { Viveiro do } \\
\text { Departamento de } \\
\text { Obras e Meio } \\
\text { Ambiente } \\
\end{array}$ & $\begin{array}{l}\text { Prefeitura } \\
\text { Municipal de São } \\
\text { Sebastião }\end{array}$ & São Sebastião & 5 & $\begin{array}{l}\text { Eng. Civil Marco } \\
\text { Tulio Parodi }\end{array}$ & \multicolumn{2}{|c|}{$124512088 / / 4521526$} \\
\hline 116 & $\begin{array}{l}\text { Estaçao Experimental } \\
\text { de Bento Quirino - } \\
\text { Instituto Florestal }\end{array}$ & Tabela IBt/SMA & São Simão & 3 & & & \\
\hline 117 & \multicolumn{2}{|c|}{$\begin{array}{l}\text { Viveiro Nativas Rio Preto - Associaçao } \\
\text { do Bairro Rio Preto }\end{array}$} & Sete Barras & 6 & $\begin{array}{l}\text { Wagner Gomes } \\
\text { Portilho }\end{array}$ & \multicolumn{2}{|c|}{$13-6822-1714$ // 13-6872-1542 } \\
\hline 118 & \multicolumn{2}{|c|}{ FLONA de Ipanema / IBAMA-Iperó } & Sorocaba & 3 & $\begin{array}{l}\text { Oscar Rensburg } \\
\text { Willmersdorf - } \\
\text { engenheiro flores tal } \\
\end{array}$ & $266-9090$ & flonadipanema@ig.com.br \\
\hline 119 & \multicolumn{2}{|c|}{$\begin{array}{l}\text { Verde Tambaút Associação de Reposição } \\
\text { Florestal do Pardo Grande }\end{array}$} & Tambaú & 3 & Ang. Antônio Carlos & $\begin{array}{l}(019) \text { 673- } \\
1313\end{array}$ & \\
\hline
\end{tabular}

Nota - Relação de viveiros de produção de mudas florestais - Banco de dados do Projeto Matrizes, disponível no site do LERF-ESALQ/USP: http://www.lerf.esalq.usp.br

Legenda: Região 1 - Noroeste; Região 2 - Sudoeste; Região 3-Centro; Região 4- Sudeste; Região 5- Litoral Norte, Região 6 - Litoral Sul. Tabela IBt/SMA - dados não divulgados pelo Instituto de Botânica (Barbosa \& Martins, 2003). 
ANEXO G - Relação de viveiros de produção de mudas de espécies nativas no Estado de São Paulo.

\begin{tabular}{|c|c|c|c|c|c|c|c|}
\hline Cod. & Nome do viv. & Instituiçao resp. & Municipio & Região & Responsavel & Fone & E-mail \\
\hline 120 & \multicolumn{2}{|c|}{$\begin{array}{l}\text { Horto Florestal "Loure nço Spiga Real" - } \\
\text { Associaçao de Reposiçao Florestal Pardo } \\
\text { Grande }\end{array}$} & Tambaú & 3 & $\begin{array}{l}\text { Eng. Antonio Carlos } \\
\text { Rosa }\end{array}$ & \begin{tabular}{|l|}
$19-673.1179 / /$ \\
$19-673.1313 / /$ \\
$19-3673-4704$
\end{tabular} & verdetam@dglnet.com.br \\
\hline 121 & \multicolumn{2}{|c|}{ Viveiro Florestal de Taubaté - IF } & Taubaté & 4 & $\begin{array}{l}\text { José Luis de } \\
\text { Carvalho }\end{array}$ & $12-226-1114$ & \\
\hline 122 & Viveiro Manacá & Tabela IBt/SMA & Taubaté & 4 & & & \\
\hline 123 & $\begin{array}{l}\text { Viveiro Agroflorestal } \\
\text { - Parque Estadual } \\
\text { Morro do Diabo } \\
\end{array}$ & $\begin{array}{l}\text { IPE- Instituto de } \\
\text { Pesquisas } \\
\text { Ecológicas e IF. }\end{array}$ & Teodoro Sampaio & 2 & $\begin{array}{l}\text { Jefferson/ Laury } \\
\text { Cullen }\end{array}$ & & \\
\hline 124 & $\begin{array}{l}\text { Viveiro Estrela Dalva } \\
\text { (Assentamento) }\end{array}$ & Tabela IBt/SMA & Teodoro $\mathrm{S}$ ampaio & 2 & & & \\
\hline 125 & $\begin{array}{l}\text { Viveiro Laudenor de } \\
\text { Souza } \\
\text { (Assentamento) }\end{array}$ & Tabela IBt/SMA & Teodoro Sampaio & 2 & & & \\
\hline 126 & \multicolumn{2}{|c|}{$\begin{array}{l}\text { Núcleo de Produçao de Mudas de Tietê - } \\
\text { DSMM/CATI }\end{array}$} & Tietê & 3 & $\begin{array}{l}\text { Eng. Victor B. } \\
\text { Araújo }\end{array}$ & $15-282.1919$ & npmzi@cati.sp.gov.br \\
\hline 127 & Sítio Guapuruvu & & Ubatuba & 5 & Carlos Amexeiro & \begin{tabular}{|l|}
$(011) 5641-$ \\
2027 \\
$(12) 38325628$ \\
\end{tabular} & carlosflorest@bol.com.br \\
\hline
\end{tabular}

Nota - Relação de viveiros de produção de mudas florestais - Banco de dados do Projeto Matrizes, disponível no site do LERF-ESALQ/USP http://www.lerf.esalq.usp.br

Legenda: Região 1 - Noroeste; Região 2 - Sudoeste; Região 3-Centro; Região 4- Sudeste; Região 5- Litoral Norte, Região 6 - Litoral Sul. Tabela IBt/SMA - dados não divulgados pelo Instituto de Botânica (Barbosa \& Martins, 2003). 


\title{
ANEXO H - Depoimentos importantes sobre a Resolução SMA 21(21/11/01).
}

\author{
Prof. Dr. José Goldemberg \\ Secretário do Meio Ambiente do Estado de São Paulo.
}

A Resolução SMA-21/01, que fixa orientação para o reflorestamento de áreas degradadas e dá providências correlatas, vem sendo aplicada pelas áreas de licenciamento e fiscalização do sistema de administração da qualidade ambiental e, tem representado ainda, um importante subsídio para a formulação de programas de recuperação de áreas degradadas, notadamente de zonas ciliares. $O$ desenvolvimento da pesquisa científica e a experiência na aplicação da Resolução SMA-21/01 desde sua edição apontam oportunidades de aperfeiçoamento do instrumento. (...) É desejável que este processo de avaliação e aprimoramento seja contínuo, permitindo que os resultados da pesquisa científica efetivamente resultem no aperfeiçoamento das políticas públicas. Adicionalmente, cabe considerar que a Resolução Secretarial é instrumento eficaz para que atinjam os objetivos pretendidos, uma vez que a sua aplicação é obrigatória para os agentes públicos responsáveis pela aprovação e acompanhamento dos projetos de recuperação de áreas degradadas.

\section{Prof. Dr. Paulo Kageyama Secretaria de Biodiversidade de Florestas-Ministério do Meio Ambiente}

O avanço nas técnicas de restauração visando melhorar o rendimento e diminuição dos custos de implantação deve ser acompanhado da melhoria da diversidade de espécies do novo ecossistema, assim como da representatividade genética nas populações dessas espécies. Dessa forma, a resolução SMA 21/01 representa um avanço na regulamentação das bases de uma restauração adequada, também no sentido genético, no Estado de São Paulo. Em sua Palestra comentou sobre a importância deste evento elogiando o Dr. Luiz Mauro Barbosa por saber encontrar o momento certo de envolver as comunidades científicas em torno de um problema que e de todos nos, como alias havia feito em 1989 quando organizou o primeiro Simpósio sobre Matas Ciliares em São Paulo, pelo Instituto ito de Botânica que foi um marco histórico e que é referência obrigatória até hoje para trabalhos sobre Recuperação de Mata Ciliares.

\section{Prof. Dr. Ricardo Ribeiro Rodrigues Departamento de Ciências Biológicas - ESALQ/USP}

A resolução SMA 21/01 tem grande importância, pois pode se consolidar como instrumento legal de restauração da biodiversidade paulista, não apenas como jargão do discurso ecológico, mas também como prerrogativa do sucesso dessas iniciativas de recuperação de áreas degradadas.

\section{Eng a . Agra . Helena Carrascosa Von Glehw CETESB-Secretaria de Estado do Meio Ambiente}

A Resolução SMA 2/01 é um bom exemplo de integração entre atividades de pesquisa e a formulação e implementação de políticas públicas, que vem sendo buscada desde a criação da SMA. O desenvolvimento de um projeto de pesquisa e os seus resultados permitiram a elaboração de um instrumento que fornece orientação para a atuação da SMA, seja em atividades de fiscalização e licenciamento e ações delas decorrentes, seja como subsídio para a formulação de programas de recuperação de áreas degradadas, como é o programa de recuperação de matas ciliares.

Nota - Depoimentos colhidos pela equipe do IBt/SMA durante o I Seminário temático sobre recuperação de áreas degradadas (SENAGO, 2003). 


\title{
ANEXO H - Depoimentos importantes sobre a Resolução SMA 21(21/11/01).
}

\author{
João Hector Lopes Zanette \\ Embrapa - Santa Catarina/RS
}

Segundo ele, em Santa Catarina ainda não existe modelo adequado de recuperação de áreas degradas, o que o motivou a vir para São Paulo participar do Seminário Temático e poder levar as experiências já implantadas no Estado com bases na Resolução SMA 21/01.

\section{Valdeci Teixeira Chaves IBAMA - Goiânia}

A demanda de recuperação de áreas degradadas no Estado de Goiás e a grande de falta legislação adequada para subsidiar olicenciamento ambiental foram os principais motivos que o fizeram participar do Seminário. Seu interesse maior no seminário temático é de poder levar as informações sobre a Resolução SMA 21/01 para que Goiás para que possa fazer algo neste sentido, ou seja, levar a experiência bem sucedida de São Paulo para Goiás.

\section{Miguel Magela Diniz International Paper do Brasil de Mogi Guaçu, SP.}

Com a adequação à Resolução SMA 21 de 21/11/2001, a International Paper está em plena evolução, tanto no setor de produção de mudas nativas, quanto na recuperação das áreas de preservação permanente (APP) e RPPN, produzindo e utilizando uma alta diversidade de espécies arbóreas nativas nos povoamentos recém -implantados nas áreas da Empresa, nas regiões de Mogi Guaçu, Aguaí e Espírito Santo do Pinhal - SP.

Concluímos que utilizando uma menor diversidade de espécies arbóreas, o custo de manutenção da floresta nativa é menor na fase inicial, devido à rápida cobertura do solo; sendo necessário no futuro o enriquecimento desse povoamento com outras espécies, o que acarretará um custo adicional.

No entanto, quando é utilizada maior diversidade florística de diferentes classes sucessionais no início do plantio, a cobertura do solo é mais lenta e conseqüentemente o custo de manutenção ra fase inicial é maior; porém, no momento acreditamos que seja a melhor alternativa econômica e operacional, tendo em vista que no futuro não será necessário efetuar o enriquecimento desse povoamento, evitando assim custos adicionais.

De acordo com orientação recebida de técnicos do Instituto de Botânica de São Paulo, com quem mantemos uma "parceria", montamos áreas demonstrativas para pesquisas "in loco" envolvendo apoio da Empresa para trabalhos acadêmicos envolvendo dissertação de mestrado e tese de doutorado, cujos resultados tem sido muito gratificante, e certamente podemos contribuir para o aperfeiçoamento da Resolução SMA-21/01, de extrema importância, pois esta consolidando um "instrumento legal" capaz de promover a restauração da diversidade específica e genética, deixando de ser uma falácia ecológica para ser um fator de sucesso nos projetos de recuperação de áreas degradadas.

\section{Prof. Dra. Vera Lex Engel Faculdade de Ciências Florestais da UNESP/Botucatu, SP.}

Em relação à Resolução SMA 21/01, recomenda-se que ela seja flexibilizada no sentido de permitir estudos caso a caso para que, em pequenas e médias propriedades e principalmente em iniciativas voluntárias de recuperação de matas (como no caso da reserva legal), possa ser dada prioridade para a utilização de espécies de interesse econômico (incluindo em alguns casos espécies exóticas), como uma etapa intermediária e seguindo-se um plano de manejo préestabelecido, para que no futuro se tenha uma floresta diversificada, composta somente com espécies nativas regionais, que é o anseio de todos.

Nota - Depoimentos colhidos pela equipe do IBt/SMA durante o I Seminário temático sobre recuperação de áreas degradadas (SENAGO, 2003). 


\title{
ANEXO H - Depoimentos importantes sobre a Resolução SMA 21(21/11/01).
}

\author{
Prof. Valdir Mantovani. \\ Instituto de Biociências/ USP
}

Propostas e ações de preservação, conservação, manejo e de recuperação de áreas degradadas, em algumas situações podem ser tratadas localmente, mas na maioria delas, devem ser abordadas sob uma ótica mais ampla, integrada. Quando se trata de biomas com ligações bióticas e funcionais amplas, como é o caso da vegetação na margem de cursos d'água, o nível de abordagem deve ser, no mínimo, das paisagens, no qual diversos ecossistemas interagem através de fluxos bióticos, de energia e de matéria. Ações locais, temporalmente estanques e isoladas raramente tendem a responder satisfatoriamente questões ambientais nos médios e longos prazos e devem ser promovidas permanentemente, requerendo um acompanhamento de monitoria e de avaliação de resultados, como parte de políticas públicas.

Este Seminário é muito importante por permitir que estas questões sejam amplamente discutidas e aprimoradas.

\section{Prof. Dr. Ademir Reis. \\ Universidade Federal de Santa Catarina}

Os programas de restauração, tradicionalmente, são executados com alguns vícios que comprometem o modelo de conservação in situ: uma visão fortemente dendrológica, com uso quase que exclusivo de espécies arbóreas; utilização de espécies exóticas, propiciando a contaminação biológica local e potencializando a degradação; tecnologias muito caras, inviabilizando pequenos projetos que possam efetivamente restaurar a biodiversidade através de processos naturais de sucessão; não utilização dos princípios básicos da sucessão primária e secundária.

O trabalho efetuado por São Paulo, capitaneada. pela Secretaria do Meio Ambiente é fantástico e deve ser seguido por outros por outros Estados. A iniciativa da Resolução SMA 21/01 e os exemplos colhidos atestam isto e realmente indicam para a necessidade de aprimoramento da referida Resolução, mas certamente foi um grande passo conseguido por São Paulo no sentido de conservar as espécies e dar sustentabilidade aos reflorestamento implantados com espécies nativas.

Nota - Depoimentos colhidos pela equipe do IBt/SMA durante o I Seminário temático sobre recuperação de áreas degradadas (SENAGO, 2003). 
ANEXO I - A Resolução SMA 21, de 21-11-01 e a proposta de alterações.

\begin{tabular}{|c|c|}
\hline \multicolumn{2}{|c|}{ Quadro comparativo das modificações realizadas na Resolução SMA 21, de 21-11-01. } \\
\hline RESOLUÇÃO SMA - 21, DE 21-11-2001 & MODIFICAÇÕES DA REUNIÃO DE 03/10/03 \\
\hline $\begin{array}{l}\text { Fixa orientação para o reflorestamento heterogêneo de áreas } \\
\text { degradadas e dá providências correlatas }\end{array}$ & Idem \\
\hline 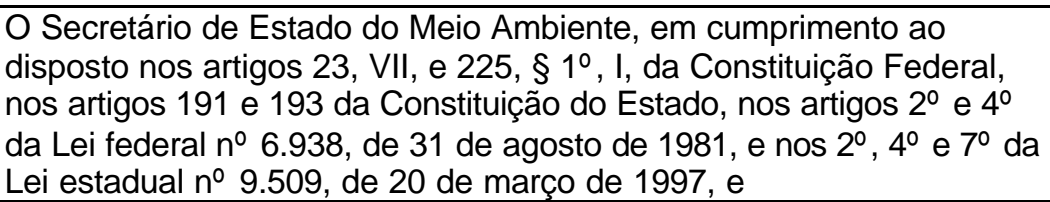 & Idem \\
\hline $\begin{array}{l}\text { Considerando o "Projeto de Produção de Mudas de Plantas Nativas - } \\
\text { Espécies Arbóreas para Recomposição Vegetal, de interesse para a } \\
\text { economia estadual", aprovado pelo Decreto no } 46.113 \text {, de } 21 \text { de } \\
\text { setembro de 2001; }\end{array}$ & $\begin{array}{l}\text { Considerando o contido na Agenda } 21 \text { e na Convenção da } \\
\text { Biodiversidade; } \\
\text { Considerando a necessidade de recomposição da cobertura } \\
\text { vegetal das Áreas de Preservação Permanente, conforme disposto } \\
\text { na Lei Estadual 9989/98; } \\
\text { Considerando o "Projeto de Produção de Mudas de Plantas } \\
\text { Nativas - Espécies Arbóreas para Recomposição Vegetal, de } \\
\text { interesse para a economia estadual", aprovado pelo Decreto no } \\
46.113 \text {, de } 21 \text { de setembro de 2001; }\end{array}$ \\
\hline
\end{tabular}

Nota: Modificações foram realizadas em reunião no IBt/ SMA em 03/10/03. A proposta será encaminhada ao Prof. Dr. Jos é Goldemberg, Secretario do Meio Ambiente do Estado de São Paulo. 
ANEXO I - A Resolução SMA 21, de 21-11-01 e a proposta de alterações.

\begin{tabular}{|c|c|}
\hline RESOLUÇÃO SMA - 21, DE 21-11-2001 & MODIFICAÇÕES DA REUNIÃO DE 03/10/03 \\
\hline $\begin{array}{l}\text { Considerando a constatação feita pela Coordenadoria de Informações } \\
\text { Técnicas, Documentação e Pesquisa Ambiental - CINP, da Pasta, } \\
\text { quanto àbaixa diversidade vegetal das áreas reflorestadas com } \\
\text { espécies nativas, nas quais têm sido utilizadas menos de } 33 \text { espécies } \\
\text { arbóreas, o que se agrava, ainda mais, quando se verifica que são } \\
\text { plantadas praticamente as mesmas espécies em todo o Estado, } \\
\text { independentemente da região, sendo } 2 / 3 \text { (dois terços) delas iniciais } \\
\text { da sucessão, de ciclo de vida curto (15-20 anos), o que irá levar os } \\
\text { reflorestamentos ao declínio em um certo espaço de tempo, como } \\
\text { vem sendo observado na prática; }\end{array}$ & $\begin{array}{l}\text { Considerando a constatação feita pela equipe do Instituto de } \\
\text { Botânica, relacionada ao projeto "Modelos de Repovoamento } \\
\text { Vegetal para Proteção de Sistemas Hídricos em Áreas } \\
\text { Degradadas dos Diversos Biomas no Estado de São Paulo" } \\
\text { (Políticas Públicas / FAPESP) quanto àbaixa diversidade vegetal } \\
\text { das áreas reflorestadas com espécies nativas, nas quais têm sido } \\
\text { utilizadas menos de } 33 \text { espécies arbóreas, o que se agrava, ainda } \\
\text { mais, quando se verifica que são plantadas praticamente as } \\
\text { mesmas espécies em todo o Estado, independentemente da } \\
\text { região, sendo } 2 / 3 \text { (dois terços) delas, em geral, iniciais da } \\
\text { sucessão, de ciclo de vida curto (15-20 anos), o que irá levar os } \\
\text { reflorestamentos ao declínio em um certo espaço de tempo, como } \\
\text { vem sendo observado na prática; } \\
\text { Considerando a necessidade de revisão periódica dos termos } \\
\text { contidos na Resolução SMA } 21 \text { tendo em vista o avanço do } \\
\text { conhecimento cientifico e resultados obtidos com sua aplicação } \\
\text { prática; }\end{array}$ \\
\hline $\begin{array}{l}\text { Considerando que a perda da diversidade biológica significa a } \\
\text { redução de recursos genéticos disponíveis ao desenvolvimento } \\
\text { sustentável, na forma de madeira, frutos, forragem, plantas } \\
\text { ornamentais e produtos de interesse alimentar, industrial e } \\
\text { farmacológico; }\end{array}$ & Idem \\
\hline
\end{tabular}

Nota: Modificações foram realizadas em reunião no IBt/ SMA em 03/10/03. A proposta será encaminhada ao Prof. Dr. José Goldemberg, Secretario do Meio Ambiente do Estado de São Paulo. 
ANEXO I - A Resolução SMA 21, de 21-11-01 e a proposta de alterações.

\section{RESOLUCÃO SMA - 21, DE 21-11-2001}

Considerando que o Departamento Estadual de Proteção de Recursos Naturais - DEPRN, da Pasta, tem constatado que os plantios realizados podem apresentar resultados mais satisfatórios quando estabelecidos critérios técnicos para a escolha e combinação das espécies, resolve:

Art. $1^{\circ}$ - Com a finalidade de ser promovido o reflorestamento heterogêneo de áreas degradadas, especialmente nas matas ciliares, - Departamento Estadual de Proteção de Recursos Naturais DEPRN, da Pasta observado o rigoroso cumprimento do disposto no Decreto $\mathrm{n}^{-}$46.113, de 21 de setembro de 2001, verificará a possibilidade, consideradas as peculiaridades locais e regionais e tanto quanto possível, do uso de espécies nativas, constantes do

Anexo a esta resolução:

I - nas seguintes proporções:

a) 30 espécies distintas para projetos de até 1 hectare;

b) 50 espécies distintas para projetos de até 20 hectares;

c) 60 espécies distintas para projetos de até 50 hectares;

d) 80 espécies distintas para projetos com mais de 50 hectares.

II - sendo priorizada a utilização de espécies ameaçadas de extinção, respeitando-se as regiões ou formações de ocorrência, na seguinte

\section{MODIFICACÕES DA REUNIÃO DE 03/10/03}

\section{Considerando que o Departamento Estadual de Proteção de} Recursos Naturais - DEPRN, tem constatado que os plantios realizados têm apresentado resultados mais satisfatórios a partir dos critérios técnicos para a escolha e combinação das espécies, estabelecidos na Resolucão SMA 21/01, resolve:

Art. 1ㅇ - Com a finalidade de promover a recuperação florestal de áreas degradadas nas formações de floresta ombrófila, floresta estacional semidecidual e savanas florestadas (cerradão). mediante o plantio de mudas, o Sistema Estadual de Meio Ambiente, observado o cumprimento do disposto no Decreto $\mathrm{n}^{\circ}$ 46.113, de 21 de setembro de 2001, determina o uso de, no mínimo, 80 (oitenta) espécies arbóreas das formações vegetais de ocorrência regional exemplificadas na listagem do Anexo a esta resolução, não excluindo espécies levantadas regionalmente.

\$1 - O caput deste artigo não se aplica para áreas de recuperacão com menos de 1,0 (um) hectare, nas quais deverão ser utilizadas. no mínimo, 30 espécies.

\$ 2 - Recomenda-se a utilização de espécies ameaçadas de extinção, respeitando-se as formações de ocorrência, e/ou atrativas da fauna associada.

§3 - As espécies escolhidas deverão contemplar os dois grupos ecológicos: pioneiras (pioneiras e secundárias iniciais) e não pioneiras (secundárias tardias e climáticas), considerando-se o

Nota: Modificações foram realizadas em reunião no IBt/ SMA em 03/10/03. A proposta será encaminhada ao Prof. Dr. Jos é Goldemberg, Secretario do Meio Ambiente do Estado de São Paulo. 
ANEXO I - A Resolução SMA 21, de 21-11-01 e a proposta de alterações.

proporção:
a) $5 \%$ (cinco por cento) das mudas, com pelo menos 5 espécies
distintas, para projetos de até 1 hectare;
b) $10 \%$ (dez por cento) das mudas, com pelo menos 10 espécies
distintas, para projetos de até 20 hectares;
c) $10 \%$ (dez por cento) das mudas, com pelo menos 12 espécies
distintas, para projetos de até 50 hectares;
d) $10 \%$ (dez por cento) das mudas, com pelo menos 15 espécies
distintas para projetos com mais de 50 hectares.
§ 1 o - No caso de áreas degradadas localizadas em restingas,
manguezais e florestas paludosas (mata de brejo):
I - as espécies selecionadas para o plantio serão escolhidas entre
espécies arbóreas de áreas naturais da vizinhança, atentando para as
variações edáficas e topográficas locais;
II - proporção de $50 \%$ (cinqüenta por cento), sempre que possível, das
espécies naturais existentes na vizinhança.
espécies naturais existentes na vizinhança.

$\S 2^{\circ}$ - As mudas a ser utilizadas deverão, preferencialmente, ser produzidas com sementes procedentes da mesma região da área objeto da recuperação e nativas do bioma ou formação florestal correspondente, bem como ter pelo menos $20 \mathrm{~cm}$ (vinte centímetros) de altura e apresentar sistema radicular e rustificação que possibilitem a sua sobrevivência pós -plantio.

limite mínimo de $40 \%$ para qualquer dos grupos.

$\$ 4$ - Com relacão ao número de indivíduos por espécie. nenhuma espécie poderá ultrapassar o limite máximo de $20 \%$ do total do plantio.

(Corresponde ao Artigo 4 e Artigo 9)

\section{(Corresponde ao Artigo 1)}

ta: Modificações foram realizadas em reunião no IBt/ SMA em 03/10/03. A proposta será encaminhada ao Prof. Dr. Jos é Goldemberg, Secretario do Meio Ambiente do Estado de São Paulo. 
ANEXO I - A Resolução SMA 21, de 21-11-01 e a proposta de alterações.

\begin{tabular}{|c|c|}
\hline RESOLUCÃO SMA - 21, DE 21-11-2001 & MODIFICACÕES DA REUNIÃO DE 03/10/03 \\
\hline $\begin{array}{l}\text { § 3 - Para a implantação das medidas de recuperação deverá ser } \\
\text { utilizado o processo sucessional como estratégia básica. }\end{array}$ & (Corresponde ao parágrafo 3 e 4 do Artigo1) \\
\hline $\begin{array}{l}\text { Art. } 2^{0} \text { - Na execução dos trabalhos de recuperação deverão ser } \\
\text { considerados o preparo do solo, as estratégias e técnicas de plantio e, } \\
\text { especialmente, a distribuição das mudas das diferentes espécies no } \\
\text { campo, além da possibilidade de auto-recuperação dessas áreas no } \\
\text { que se refere à possibilidade da presença ou chegada de propágulos } \\
\text { (sementes ou indivíduos remanescentes) oriundos do banco de } \\
\text { sementes e da "chuva" de sementes, dependendo do local da área } \\
\text { objeto de recuperação e da vizinhança, devendo, ainda, levar em } \\
\text { conta a presença de remanescentes florestais próximos e considerar } \\
\text { o histórico e uso atual da área, no que se refere à práticas culturais, } \\
\text { com alteração da drenagem do solo, retirada ou revolvimento } \\
\text { periódico do solo, uso de herbicidas e outros. }\end{array}$ & $\begin{array}{l}\text { Art. } 2^{\circ} \text { - A recuperação de áreas degradadas exige elevada } \\
\text { diversidade, que pode ser obtida com o plantio de mudas e/ou } \\
\text { outras técnicas tais como semeadura direta, indução e/ou } \\
\text { condução da regeneração natural } \\
\text { (Corresponde: } \\
\text { aos parágrafos } 1 \text { e } 2 \text { do Artigo 5; } \\
\text { ao Artigo 7; } \\
\text { ao Artigo 8) }\end{array}$ \\
\hline $\begin{array}{l}\S 1^{0} \text { - As áreas reflorestadas deverão ser conservadas mediante o } \\
\text { controle de formigas, realização de, no mínimo, } 3 \text { (três) capinas e/ou } \\
\text { coroamento anuais, mantendo as entrelinhas vegetadas e baixas e, } \\
\text { se possível, efetuar, pelo menos, duas adubações anuais com } \\
\text { formulação normalmente utilizadas na região, ou de acordo com os } \\
\text { resultados da análise do solo. } \\
\S 2^{\circ} \text { - Nas restingas, manguezais e florestas paludosas (mata de } \\
\text { brejo), deverá ser promovida a restauração da hidrodinâmica do solo } \\
\text { e,no caso de áreas com retirada ou revolvimento anterior do solo, da } \\
\text { sua estrutura. }\end{array}$ & $\begin{array}{l}\text { (Corresponde: } \\
\text { aos parágrafos } 1 \text { e } 2 \text { do Artigo 5; } \\
\text { ao Artigo 7; } \\
\text { ao Artigo 8) } \\
\text { (Corresponde: } \\
\text { aos parágrafos } 1 \text { e } 2 \text { do Artigo 5; } \\
\text { ao Artigo 7; } \\
\text { ao Artigo } 8\end{array}$ \\
\hline
\end{tabular}

Nota: Modificações foram realizadas em reunião no IBt/ SMA em 03/10/03. A proposta será encaminhada ao Prof. Dr. Jos é Goldemberg, Secretario do Meio Ambiente do Estado de São Paulo. 
ANEXO I - A Resolução SMA 21, de 21-11-01 e a proposta de alterações.

\begin{tabular}{|c|c|}
\hline RESOLUÇÃO SMA - 21, DE 21-11-2001 & MODIFICAÇÕES DA REUNIÃO DE 03/10/03 \\
\hline $\begin{array}{l}\text { Art. } 3^{\circ} \text { - A Secretaria do Meio Ambiente, mediante programas } \\
\text { específicos, estimulará o desenvolvimento de pesquisas para o } \\
\text { aprimoramento do conhecimento científico das medidas estabelecidas } \\
\text { nesta resolução, visando ampliar os conhecimentos sobre ecologia } \\
\text { das espécies e formações e sobre tecnologia de produção de } \\
\text { sementes e mudas, bem como estabelecer modelos alternativos para } \\
\text { a recuperação de áreas degradadas, em conjunto com outras } \\
\text { Secretaria de Estado, Universidades, instituições científicas, Poderes } \\
\text { Públicos das demais esferas de governo e organizações não } \\
\text { governamentais. }\end{array}$ & (Corresponde ao Artigo 11) \\
\hline $\begin{array}{l}\text { Artigo 4 - Esta resolução entra em vigor na data de sua publicação. } \\
\text { Publicado novamente por ter saído com incorreções no D.O. de } 22 \text { - } \\
\text { 11-2001. }\end{array}$ & (Corresponde ao Artigo13) \\
\hline $\begin{array}{l}\text { Anexo á Resolução SMA 21, de 21-11-01 Listagem das espécies } \\
\text { arbóreas, com a indicação do Bioma/ Ecossistema de ocorrência } \\
\text { natural no Estado de São Paulo e a classe sucessional a que } \\
\text { pertencem. }\end{array}$ & (Corresponde ao Artigo12) \\
\hline & $\begin{array}{l}\text { Art. } 3 \text { - Na execução dos trabalhos de recuperação florestal, } \\
\text { deverão ser priorizadas as seguintes áreas: } \\
\text { a) de nascentes e olhos d'água; } \\
\text { b) de interligação de fragmentos florestais remanescentes na } \\
\text { paisagem regional (corredores ecológicos); } \\
\text { c) de elevado potencial de erodibilidade; }\end{array}$ \\
\hline
\end{tabular}

Nota: Modificações foram realizadas em reunião no IBt/ SMA em 03/10/03. A proposta será encaminhada ao Prof. Dr. Jos é Goldemberg, Secretario do Meio Ambiente do Estado de São Paulo. 
ANEXO I - A Resolução SMA 21, de 21-11-01 e a proposta de alterações.

\begin{tabular}{|c|c|}
\hline RESOLUÇÃO SMA - 21, DE 21-11-2001 & MODIFICAÇÕES DA REUNIÃO DE 03/10/03 \\
\hline & $\begin{array}{l}\text { Art. } 4^{\circ} \text { - Para formações ou situações de baixa diversidade } \\
\text { natural, tais como: florestas estacionais deciduais, formações } \\
\text { paludosas e de restinga, manguezal e áreas rochosas, o número } \\
\text { de espécies a ser utilizado será definido por projeto técnico } \\
\text { circunstanciado, considerando-se a maior diversidade possível. }\end{array}$ \\
\hline & $\begin{array}{l}\text { Art. 5o - Para projetos de recuperação mediante plantio, o solo } \\
\text { deverá ser devidamente preparado, atentando para as } \\
\text { recomendações técnicas de conservação de solo, de calagem e } \\
\text { adubação, do controle inicial de competidores, além de isolar a } \\
\text { área dos fatores de degradação. } \\
\text { § } 1 \text { - A manutenção das áreas restauradas deverá ser executada } \\
\text { por, no mínimo, } 18 \text { meses após o plantio, incluindo o controle de } \\
\text { formigas, capinase/ou coroamentos, adubação e outros, conforme } \\
\text { avaliação técnica do responsável pelo projeto. } \\
\text { § } 2 \text { - Tendo como objetivo final a recuperação da floresta, será } \\
\text { admitida a ocupação das entrelinhas, com espécies para adubação } \\
\text { verde e/ou de interesse econômico, por até dois anos, desde que o } \\
\text { projeto utilize princípios agro-ecológicos. }\end{array}$ \\
\hline
\end{tabular}

Nota: Modificações foram realizadas em reunião no IBt/ SMA em 03/10/03. A proposta será encaminhada ao Prof. Dr. José Goldemberg, Secretario do Meio Ambiente do Estado de São Paulo. 
ANEXO I - A Resolução SMA 21, de 21-11-01 e a proposta de alterações.

\begin{tabular}{|c|c|}
\hline RESOLUÇÃO SMA - 21, DE 21-11-2001 & MODIFICAÇÕES DA REUNIÃO DE 03/10/03 \\
\hline & $\begin{array}{l}\text { Art. 6- -Para recuperação de áreas com algum tipo de cobertura } \\
\text { florestal nativa remanescente, recomenda-se: } \\
\text { a) a proteção da área de qualquer açãa de degradação; } \\
\text { b) o controle de espécies exóticas ou nativas em desequilibrio; } \\
\text { c) o adensamento na borda da área, usando espécies de rápido } \\
\text { crescimento e boa cobertura; } \\
\text { d) o enriquecimento dessas áreas com espécies finais da } \\
\text { sucessão. }\end{array}$ \\
\hline & $\begin{array}{l}\text { Art. 7o - Para a recuperação de áreas degradadas mediante outras } \\
\text { técnicas, associadas ou não ao plantio de mudas, deverá ser } \\
\text { apresentado um projeto especifico, contendo: } \\
\text { a) avaliação da paisagem; } \\
\text { b) avaliação do histórico de degradação da área; } \\
\text { c) retirada dos fatores de degradação; } \\
\text { d) avaliação dos processos de regeneração natural; } \\
\text { e) aproveitamento do potencial de auto-recuperação. } \\
\text { \$ Único - A não presença e/ou expressão deste potencial de auto- } \\
\text { recuperação remete ao artigo } 1^{\circ} \text {. }\end{array}$ \\
\hline
\end{tabular}

Nota: Modificações foram realizadas em reunião no IBt/ SMA em 03/10/03. A proposta será encaminhada ao Prof. Dr. José Goldemberg, Secretario do Meio Ambiente do Estado de São Paulo. 
ANEXO I - A Resolução SMA 21, de 21-11-01 e a proposta de alterações.

\begin{tabular}{|c|c|}
\hline RESOLUÇÃO SMA - 21, DE 21-11-2001 & MODIFICAÇÕES DA REUNIÃO DE 03/10/03 \\
\hline & $\begin{array}{l}\text { Art. 8 - A execução dos trabalhos de recuperação florestal deverá } \\
\text { observar os seguintes aspectos: } \\
\text { I - O solo deverá ser preparado em consonância com a estratégia } \\
\text { de recuperação adotada, atentando para as recomendações } \\
\text { técnicas de conservação de solo, de calagem, adubaçâo e } \\
\text { aplicação de matéria orgânica, com destaque para análise físico- } \\
\text { química do solo; } \\
\text { II - Avaliação do potencial de auto-recuperação dessas áreas no } \\
\text { que se refere: àpresença ou chegada de propágulos (sementes ou } \\
\text { indivíduos remanescentes), oriundos do banco de sementes e da } \\
\text { "chuva" de sementes, dependendo da área-objeto de recuperação } \\
\text { e da vizinhança, em função da presença de remanescentes } \\
\text { florestais próximos; } \\
\text { III- Avaliação do histórico e uso atual da área, no que se refere às } \\
\text { práticas culturais, como alteração da drenagem do solo, retirada ou } \\
\text { revolvimento periódico do solo, uso de herbicidas e outros; } \\
\text { IV - Em situaçães onde for observada a regeneração natural de } \\
\text { espécies nativas, no pré e pós-plantio, esta deverá ser aproveitada } \\
\text { na recuperação da área, estimulando e conduzindo os indivíduos } \\
\text { regenerantes através de práticas silviculturais; }\end{array}$ \\
\hline
\end{tabular}

Nota: Modificações foram realizadas em reunião no IBt/ SMA em 03/10/03. A proposta será encaminhada ao Prof. Dr. Jos é Goldemberg, Secretario do Meio Ambiente do Estado de São Paulo. 
ANEXO I - A Resolução SMA 21, de 21-11-01 e a proposta de alterações.

\begin{tabular}{|l|l|}
\hline RESOLUÇÃO SMA - 21, DE 21-11-2001 & \multicolumn{1}{|c|}{ MODIFICAÇÕES DA REUNIÃO DE 03/10/03 } \\
\hline & $\begin{array}{l}\text { V - A área de recuperação deverá ser isolada dos fatores de } \\
\text { degradação; } \\
\text { VI - Deverá haver controle de formigas cortadeiras e de espécies } \\
\text { competidoras indesejáveis, especialmente gramíneas e cipós; }\end{array}$ \\
\hline & $\begin{array}{l}\text { Artigo 9o - Na recuperação de áreas de restinga, manguezais e } \\
\text { formaçós paludosas deverá ser promovida a restauração da } \\
\text { hidrodinâmica do solo e, no caso de áreas com retirada ou } \\
\text { revolvimento anterior do solo, de suas características físico- } \\
\text { químicas; }\end{array}$ \\
\hline $\begin{array}{l}\text { Artigo 10o- Serão dispensados de apresentação de projeto } \\
\text { técnico, com a devida Anotação de Responsabilidade Técnica } \\
\text { (ART), os seguintes casos: } \\
\text { I- Áreas de recuperação até 1,0 (hum) hectares; } \\
\text { II - Proprietários rurais de áreas de até dois módulos rurais, } \\
\text { independentemente da área do projeto; }\end{array}$ \\
\hline
\end{tabular}

Nota: Modificações foram realizadas em reunião no IBt/ SMA em 03/10/03. A proposta será encaminhada ao Prof. Dr. José Goldemberg, Secretario do Meio Ambiente do Estado de São Paulo. 
ANEXO I - A Resolução SMA 21, de 21-11-01 e a proposta de alterações.

\begin{tabular}{|c|c|}
\hline RESOLUÇÃO SMA - 21, DE 21-11-2001 & MODIFICAÇÕES DA REUNIÃO DE 03/10/03 \\
\hline & $\begin{array}{l}\text { Art. } 12 \text { - A Secretaria Estadual do Meio Ambiente deverá atualizar, } \\
\text { anualmente, a listagem exemplificava das espécies florestas } \\
\text { nativas de ocorrência nos diversos biomas do Estado de São } \\
\text { Paulo. }\end{array}$ \\
\hline & $\begin{array}{l}\text { Art. 130-Esta resolução entra em vigor na data de sua publicação, } \\
\text { revogando-se as disposiçōes em contrário. }\end{array}$ \\
\hline
\end{tabular}




\section{REFERÊNCIAS BIBLIOGRAFICAS}

ANDRADE, C.S.A.; RIBEIRO, M.T.F.; GÓES, M.F.B. et al. Conflitos sócioambientais: análise da relação entre o Complexo do Sauípe e atores locais. In: ENCONTRO NACIONAL DE PÓS-GRADUAÇÃO E PESQUISA EM AMBIENTE E SOCIEDADE, 1., Indaiatuba, 2002. Anais. Indaiatuba: ANPPAS, 2002. p.1-11.

BARBOSA, L.M.; MANTOVANI, W. Degradação ambiental: conceituação e bases para o reflorestamento vegetal. In: WORKSHOP SOBRE RECUPERAÇÃO DE ÁREAS DEGRADADAS DA SERRA DO MAR E FORMAÇÕES FLORESTAIS LITORÂNEAS, São Sebastião, 2000. Documentos ambientais. São Paulo: SMA, 2000. p.33-38.

BARBOSA, L.M. Recuperação de áreas degradadas: o que precisa mudar. http://www.estadão.com.br/ciencia/colunas/aspas/2002/jul/19/50.htm. jun. 2002a)

BARBOSA, L.M. Estado da arte: balanço dos avanços e carências em relação às conclusões e recomendações do I Simpósio sobre mata ciliar. /Apresentado ao Workshop Matas Ciliares, São Paulo, 2002b/

BARBOSA, L.M.; MARTINS, S.E. Diversificando o reflorestamento no Estado de São Paulo: espécies disponíveis por região e ecossistema. São Paulo: IBt/SMA, 2003. 64p. (Manual, 10)

BARROS, R.R. Marcação de matrizes na região da baía de llha Grande - RJ. In: Workshop sobre seleção e marcação de matrizes. São Paulo: Instituto Florestal, ago. 2003. p.45-51. (IF Série Registros, 25)

BEDUSCHI FILHO, L.C. Assentamentos rurais e conservação da natureza: do estranhamento àação coletiva. São Paulo: Iglu/ FAPESP, 2003. 104p.

BRANDÃO, C.R. (Org.). Repensando a pesquisa participante. São Paulo: Brasiliense, 1985. 252p. 
BRASIL. Constituição (1988). Constituição da República Federativa do Brasil: cap.VI, Art.225. http://www.presidencia.gov.br/ccivil_03/Constituição /Constituição. htm (05 jun. 2003)

BUDOWSKI, G. Distribuition of tropical american rain forest species in the light of successional process. Turrialba, v.15, n.1, p.40-42, 1965.

BUTTEL, F. Instituições ambientais e mudanças ambientais. Idéias: Revista do Instituto de Filosofia e Ciências Humanas, v.8, n.2, p.9-37, 2001.

CALLON, M. The sociology of an actor-network: the case of electric vehicle. In: CALLON, M.; LAW, J.; RIP, A. (Ed.). Mapping the dynamics of science an technology: sociology of science in the real world. Londres: The Macmillan Press, 1986. 189p.

CARON, D.; WONGTSCHOWSKI, M. Environmet policies and tradicional communities in brazilian atlantic forest. In: CONGRESSO MUNDIAL DE SOCIOLOGIA RURAL, 10.; CONGRESSO BRASILEIRO DE SOCIOLOGIA RURAL, 28., Rio de Janeiro, 2000. Resumos. Rio de Janeiro: UNICAMP/IRSA/SOBER, 2000. p.132.

CASTANHEIRA, S.A.; CARRASCO, P.G. O efeito da Resolução SMA 21 de 21/11/2001 sobre ecossistemas de restinga e manguezal. In: SEMINÁRIO TEMÁTICO SOBRE RECUPERAÇÃO DE ÁREAS DEGRADADAS, São Paulo, 2003. Anais. São Paulo: Instituto de Botânica/SMA, 2003. p.67-71.

CATTON, W. ; DUNLAP, R. Environmental sociology: a new paradigm. The American Sociologist, v.13, n.1, p.41-49, Feb. 1998.

COMPANHIA DE TECNOLOGIA DE SANEAMENTO AMBIENTAL. Mapa da divisão regional do Departamento Estadual de Proteção dos Recursos Naturais. http://www.cetesb.sp.gov.br/licencia/dprn_regionais.htm (15 out. 2003)

CONSERVATION INTERNATIONAL DO BRASIL. Avaliação e ações prioritárias para a conservação da biodiversidade da mata atlântica e campos sulinos. Brasília: Ministério do Meio Ambiente, Secretaria de Biodiversidade e Florestas, 2000. 40p.

CORDEIRO, L.E.; CULLEN JR, L.; CARON, D. Forest plantations in agrarian reform settlements. In: CONGRESSO MUNDIAL DE SOCIOLOGIA RURAL, 10.; CONGRESSO DE BRASILEIRO DE SOCIOLOGIA RURAL, 28., Rio de Janeiro, 2000. Resumos. Rio de Janeiro: UNICAMP/IRSA/SOBER, 2000. p.249. 
COUTINHO, E.L.; MARTINS, L.; CALIARI, M.F.; NETO, M.L. Legislação e qualidade de sementes no Brasil. In: Workshop sobre seleção e marcação de matrizes. São Paulo: Instituto Florestal, ago. 2003. p.13-30. (IF Série Registros, 25)

CURRENT, D. Los sistemas agroforestales generan beneficios para las comunidades rurales? Resultados de una Investigación en América Central y el Caribe. Agroforesteria en las Americas, v.4, n.6, p.8-14, oct./dic. 1997.

DEAN, W. With broadax and firebrand: the destruction of the brazillian atlantic forest. Berkeley: University of California Press, 1995. 484p.

DIAS, L.E.; GRIFFITH, J.J. Conceituação e caracterização de áreas degradadas. In: DIAS, L.E.; MELLO, J.W.V. (Ed.). Recuperação de áreas degradadas. Viçosa: s. ed., 1998. p.1-9.

DITT, E.H. Fragmentos florestais no Pontal do Paranapanema. São Paulo: Annablume/ Ipê/ IIEB, 2002. 140p.

ECKERSLEY, R. Environmentalism and political theory. London: UCL Press, 1995. 262p.

FERREIRA, Leila C. Conflitos sociais contemporâneos: considerações sobre o ambientalismo brasileiro. Ambiente \& Sociedade, v.2, n.5, p.35-54, 1999.

FERREIRA, Leila C. Sociologia ambiental, teoria social e produção intelectual no Brasil. Idéias: Revista do Instituto de Filosofia e Ciências Humanas, v.8, n.2, p.39-70, 2001.

FERREIRA, Leila C. Brazilian environmental sociology: a provisional review. Ambiente \& Sociedade, v.5, n.10, p.27-43, 2003.

FERREIRA, Lucia C. Os fantasmas do Vale: a questão ambiental e a cidadania. Campinas: UNICAMP, 1993. 188p.

FERREIRA, Lucia C. A floresta intransitiva: conflitos e negociações na Mata Atlântica, SP. Campinas, 1996. 257p. Tese (Doutorado) - Universidade Estadual de Campinas.

FERREIRA, Lucia C.; SIVIERO, S. de O.; CAMPOS, S.V. de et al. Conflitos sociais em áreas protegidas no Brasil: moradores, instituições e ONGs no Vale do Ribeira e litoral sul-SP. Idéias: Revista do Instituto de Filosofia e Ciências Humanas, v.8, n.2, p.115-149, 2001. 
FERRETTI, A.C. O fomento florestal da CESP/Porto Primavera com propriedades da região de Assis - SP. Piracicaba, 2000. 156p. Dissertação (Mestrado) - Escola Superior de Agricultura "Luiz de Queiroz", Universidade de São Paulo.

FINEGAN, B. Forest succession: review article. Nature, v.312, n.8, p.109-114, Nov. 1984.

FREIRE, P. Extensão ou comunicação? 3.ed. Rio de Janeiro: Paz e Terra, 1977. 93p.

FUKS, M. Arenas de ação e debate público: os conflitos ambientais e a emergência do movimento ambientalista enquanto problema social no Rio de Janeiro. Rio de Janeiro, 1997. 197p. Tese (Doutorado) - Instituto Universitário de Pesquisas do Rio de Janeiro.

INSTITUTO BRASILEIRO DE GEOGRAFIA E ESTATÍSTICA. Base de informações municipais: cidades. http://www.ibge.gov.br/cidadesat1997/ default.php (05 ago. 2003)

GUIVANT, J. Conflitos e negociações nas políticas de controle ambiental. Ambiente \& Sociedade, v.1, n.2, p.101-123, 1998.

HABERMAS, J.A. New social movements. Telos, v.49, p.33-37, 1981

HANNINGAN, J. Enviromental sociology: a social constructionist perspective. Londres: Routledge, 1995. 269p.

$\mathrm{JACOBI}$, P. Meio ambiente e redes sociais: dimensões intersetoriais e complexidade na articulação da práticas coletivas. http://www. memoriadomeioambiente.org.br/biblioteca/artigos.asp (25 maio 2002)

JOHN, L. Sobram viveiros de mudas, mas faltam sementes de plantas nativas. O Estado de São Paulo, São Paulo, 18 maio 2003. p.A-14.

KAGEYAMA, P.Y. Fatores que afetam a produção de sementes florestais. In: SIMPOSIO BRASILEIRO SOBRE TECNOLOGIA DE SEMENTES FLORESTAIS, 1., Belo Horizonte, 1984. Anais. Brasília: IBDF, 1986. p.11-33.

KAGEYAMA, P.Y.; GANDARA, F.B. Biodiversidade e restauração de florestas tropicais. In: SIMPÓSIO SOBRE RESTAURAÇÃO ECOLÓGICA DE ECOSSISTEMAS NATURAIS, 1., Piracicaba, 1999. Resumos. Piracicaba: IPEF, 1999. P.57. 
KAGEYAMA, P.Y.; GANDARA, F.B. Recuperação de áreas degradadas. In: RODRIGUES, R.R.; LEITÂO-FILHO, H. Matas ciliares: conservação e recuperação. São Paulo: EDUSP/FAPESP, 2000. cap.15, p.249-270.

LATOUR, B. A profissão de pesquisador: olhar de um antropólogo. Trad. de Pedro Vieira Abramovay. Paris: Instituto Nacional de Pesquisa Agronômica, 1994. 25p.

LATOUR, B. Ciência em ação: como seguir cientistas e engenheiros sociedade afora. São Paulo: UNESP, 2000. 437p.

LAW, J.; CALLON, M. The life and death of an aircraft: a network analysis of technical chanage. In: BIJKER, W.E.; LAW, J. (Ed.). Shaping technology/ Building society: studies in sociotechnical change. Londres: The MIT Press, 1992. cap.4, p.124-136.

LEVI, M. Uma lógica da mudança institucional. Dados: Revista de Ciências Sociais, v.34, n.1, p.79-99, 1991.

LONG, N. Introduction: the raison d'être for studing rural development interface, In: LONG, N. (Ed.). Encounters at the interface: a perspective on social discontinuities in rural development. Wageningen: Wageningen Agricultural University Press, 1989. p.5-7.

LOPES, S.A. A teia invisível: Informação e contra-informação nas redes de ONGs e movimentos sociais. Rio de Janeiro, 1996. 281p. Tese (Doutorado) - Universidade Federal do Rio de Janeiro.

LORZA, R.F. (Coord.). Gupo 3: categorias de produção de sementes. In: Workshop sobre seleção e marcação de matrizes. São Paulo: Instituto Florestal, ago. 2003. p.81-87. (IF Série Registros, 25)

MANTOVANI, W. A região litorânea paulista. In: WORKSHOP SOBRE RECUPERAÇÃO DE ÁREAS DEGRADADAS DA SERRA DO MAR E FORMAÇÕES FLORESTAIS LITORÂNEAS, São Sebastião, 2000. Documentos ambientais. São Paulo: SMA, 2000. p.23-33.

MATER NATURA. Ecolista: cadastro nacional de instituições ambientalistas. 2.ed. Curitiba: WWF, 1996. 348p.

NAÇÕES UNIDAS. Princípio 13: declaração do Rio sobre ambiente e desenvolvimento. Rio de Janeiro, 1992. (Ficha Documental de Legislação, Cód.6180) http://www.diramb.gov.pt/ data/basedoc/TXT_LI_6180_1_0001. htm\#top (23 out. 2003) 
NORGAARD, R.B. O crescimento da economia global de trocas e a perda da diversidade biológica. In: WILSON, E.O. (Ed.). Biodiversidade. Rio de Janeiro: Nova Fronteira, 1997. cap. 23, p.261-274.

OFFE, C. New social movement: challenging the boundaires of institucional politics. Social Research, v.52, n.4, p.817-868, 1985.

OLSON, M. A lógica da ação coletiva: os benéficos públicos e uma teoria dos grupos sociais. Trad. de Fábio Fernandez. São Paulo: EDUSP, 1999. 208p. (Clássicos, 16)

OSTROM, E. El gobierno de los bienes comunes: la evolución de las instituiciones de acción colectiva. Trad. de C.I. Calvo e A. Sandoval. México: Universidad Nacional Autónoma de México/CRIM/FCE, 1990. $395 p$.

PIÑA-RODRIGUES, F.C.M. (Coord.). Grupo 1: proposta de legislação para o setor de produção de sementes florestais. In: Workshop sobre seleção e marcação de matrizes. São Paulo: Instituto Florestal, ago. 2003. p.61-73. (IF Série Registros, 25)

PRINS, K. Rutas y redes de la extensión. Agroforesteria en las Americas, v.6, n.21, p.21-25, 1999.

RESENDE, R.U. As regras do jogo: legislação florestal e desenvolvimento sustentável no Vale do Ribeira. São Paulo: Annablume/FAPESP, 2002. $198 p$.

RESERVA DA BIOSFERA DA MATA ATLÂNTICA. SNUC - Sistema nacional de unidades de conservação: texto lei 9985 de 18 de Julho de 2000. São Paulo: Instituto Florestal/Secretaria de Estado do Meio, 2000. 47p. (Série Cadernos da Reserva da Biosfera da Mata Atlântica)

REY, A.C.; TERCERO, V.; SEQUEIRA, W; CASTANEDA, F. Redes y comisiones agroforestales nacionales. Agroforesteria en las Americas, v.6, n.21, p.26-28, 1999.

RODRIGUES, R.R.; GANDOLFI, S. Recomposição de florestas nativas: princípios gerais e subsídios para uma definição metodológica. Revista Brasileira de Horticultira, v.2, n.1, p.4-15, 1996.

RODRIGUES, R.R.; GANDOLFI, S. Conceitos, tendências e ações para a recuperação de florestas ciliares. In: RODRIGUES, R.R.; LEITÃO-FILHO, H. Matas ciliares: conservação e recuperação. São Paulo: EDUSP/FAPESP, 2000. cap.15, p.235-248. 
ROZZA, A.F.; RODRIGUES, R.R.; BEDUSCHI, L.E.C.; MUNIZ, M.R.A. Recuperação florestal e produção de sementes e mudas de espécies nativas: projeto "Matrizes de Árvores Nativas". In: CONGRESSO FLORESTAL BRASILEIRO - BENEFÍCIOS, PRODUTOS E SERVIÇOS DA FLORESTA, 8., São Paulo, 2003. Anais. São Paulo: SBS, 2003. p.14.

SAMPAIO, J.A.L. Desafios da proteção do meio ambiente. http:// www.ecolatina.com.br/download/Jose_adercio_O_Ministerio_Pub.Fed.doc. (27 jan. 2003)

SÃO PAULO (São Paulo). Secretaria de Estado do Meio Ambiente. Inventário florestal do Estado de São Paulo. São Paulo: Instituto Florestal/SMA, 1993. 199p.

SÃO PAULO (São Paulo). Secretaria de Estado do Meio Ambiente. Compromisso de ajustamento de conduta ambiental. São Paulo: CETESB/SMA, 1997. 19p.

SÃO PAULO (São Paulo). Secretaria de Estado do Meio Ambiente. Diagnóstico ambiental participativo do Vale do Ribeira e litoral sul de São Paulo: subsídios para discussão do plano de ação governamental para o desenvolvimento sustentável. São Paulo: IBAMA/SMA/UNICAMP, 1998. p.85.

SEMINÁRIO TEMÁTICO SOBRE RECUPERAÇÃO DE ÁREAS DEGRADADAS, São Paulo: 2003. Anais. São Paulo: Instituto de Botânica/SMA, 2003. 166p.

SENAGA, M. Seminário temático realizado no Instituto de Botânica discute novas alternativas para recuperação de áreas degradadas: depoimentos importantes. http://ibot.gov.sp.br/Destaque/semin_discute.htm (15 set. 2003)

SETZER, J. Atlas climático e ecológico do Estado de São Paulo. São Paulo: Comissão interestadual da Bacia Paraná-Uruguai e centrais elétricas do Estado de São Paulo. 1966. 61p.

TAVOLARO, S.B. de F. Movimento ambientalista e modernidade: sociabilidade, risco e moral. São Paulo: Annablume/FAPESP, 2001. 226p. 
THIOLLENT, M. Metodologia da pesquisa-ação. São Paulo: Ed. Cortez, 1986. 112p.

VELOSO, H.P. (Org.). Manual técnico da vegetação brasileira. Rio de Janeiro: IBGE, Depto. de Recursos Naturais e Estudos Ambientais, 1992. 93p.

VIOLA, E.J. O movimento ambientalista no Brasil (1971-1991): da denúncia e conscientização pública para a institucionalização e o desenvolvimento sustentável. In: GOLDENBERG, M. Ecologia, ciência e política: participação social, interesses em jogo e luta de idéias no movimento ecológico. Rio de Janeiro: Revan, 1991. p.49-76.

VIOLA, E.J.; LEIS, H.; FERREIRA, L.C. Confronto e legitimação (1970 a 1990). In: CAPOBIANCO, J.P.R.; SVIRKY, E. Ambientalismo no Brasil: passado, presente e futuro. São Paulo: Instituto Socioambiental/ Secretaria do Meio Ambiente do Estado de São Paulo, 1997. 112p.

WATANABE, S. Glossário de ecologia. São Paulo: Academia de Ciências do Estado de São Paulo, 1997. 357p. (Publicações ACIESP, 103)

WITHIMORE, T.C. Forty years of rain forest ecology: 1984-1988 in perspective. GeoJournal, v.19, n.4, p.347-360, 1989. 
APÊNDICES 
APÊNDICE 1 - Reportagem sobre a produção de sementes e mudas nativas.

\section{Sobram viveiros de mudas, mas faltam sementes de plantas nativas}

\section{Botânico está fazendo} levantamento de 14 mil matrizes de 600. espécies em todo o Estado

$\mathrm{P}$ IRACICABA - A capacidade de produzir mudas de árvores nativas já não é, hoje, o principal fator limitante do reflorestamento de matas ciliares. Existem muitos viveiros no Estado com capacidade ociosa, produzindo um número menor de espécies do que teriam condições. $\mathrm{O}$ que falta são sementes.

É um desafio obter sementes de 100 a 120 espécies arbóreas diferentes, que frutificam em épocas variadas e têm exigências de manipulação diversas. Além disso as matrizes, normalmente, ficam nos poucos remanescentes florestais não-degradados, que são ou propriedades particulares ou parques e reservas, de onde é proibido tirar recursos naturais.

O desafio é ainda maior quando se verifica que, além da diversídade de espécies, os modelos produtivos de plantio de nativas exigem alta diversidade genética. Ou seja, as sementes de uma mesma espécie, destinadas a uma mesma área, não podem ser coletadas de uma úni- ca matriz. As árvores irmãs não podem ser plantadas juntas. É preciso obter sementes de $10 \mathrm{ou}$ 12 matrizes diferentes para cada espécie.

Dessa dificuldade nasceu o programa Trilhas de Matrizes, coordenado pelo botânico $\mathrm{Ri}$ cardo Ribeiro Rodrigues, do Laboratório de Ecologia e Restauração Florestal (Lerf) da Escola Superior de Agricultura Luiz de Queiroz. Com a ajuda dos estudantes de graduação e pósgraduação, ele vem fazendo o levantamento das matrizes de espécies de floresta existentes nas seis regiōes ecológicas do Estado, que se dividem entre o planalto ocidental, o planalto paulista e o litoral.

"São duas trilhas de matrizes para cada regiáo, num total de 14 mil matrizes de 600 espécies diferentes", diz o pesquisador. "A lista está crescendo e deve chegar a 800 espécies, em todo o Estado." Todas estão ou serão marcadas com uma placa de identificação e suas características - botânicas, ecológicas, época de floração, frutificação, produção, dormência, forma de coleta das sementes - constam de um banco de dados, que ainda neste semestre estará disponível para qualquer pessoa, via internet. (i.d.) 
APÊNDICE 2 - Convite e Programação do Workshop regional de Mogi Guaçu.

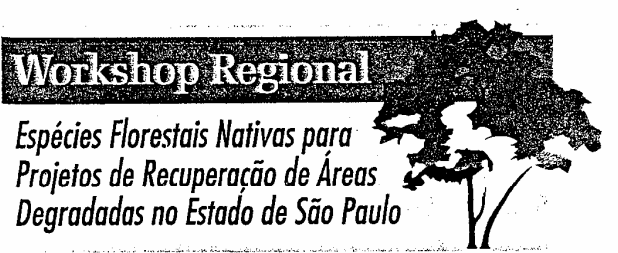

Parque Floresta 5 ăo Marcelo - International Paper

Rodovia SP $340-\mathrm{km} 171$

viogi Guaçu, $\mathrm{S}$

Objetivos

- Ampliar a articulação e a integração das instituiçōes e lideranças que

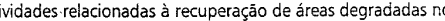

thes de projetos que incentivam a produçao regionalizada de -

ambiental te justamento de conduta ambiental.

Público Alvo

Ministerio Público, DEPRN, Policia Florestal, viveriristas e associaçōes de reposição florestal, proprietários rurais, pesquisadores e profissionais envolvidos com recuperaçăo de áreas degradadas.

Coordenaçăó

Adrianá de Fátima Rozza - ESALQ/USP

作 Vera Scholze Borges - Embrapa Transiferência de Tecnologia

Adriana Potomati - CINP/SMA

Benedito Vastano Ir. - International Pap
Cláudia lannelli - International Paper

láudia lannelli - International Paper

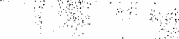

Programação

Credentrento e distribuiçăo de material do Workshop

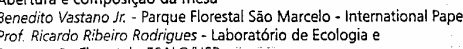

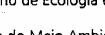

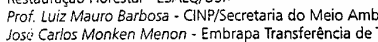

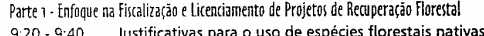

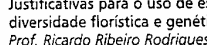

9:40 - 10:00 Recuperaçao de Áreas Degradadas:
Prof. Luiz Mauro Barbosa - CINPISMA

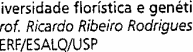

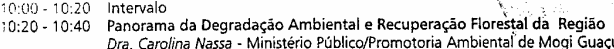

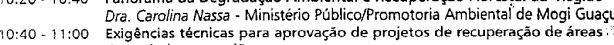

degradadab na regiá.
Engo Agrón omo Paulo Roberto Bantin - DEPRN - Mogi Guaçu

12:00-13:30 Almoço

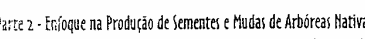

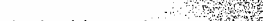

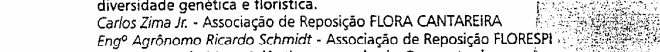

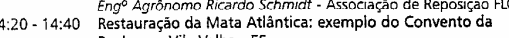

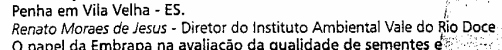

14:40 - 15:00 0 :

mudas arbbreas nativas.

$5: 00-15: 20$
$5: 20 \cdot 15: 40$

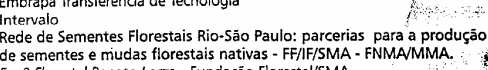

15:40 - 16:00

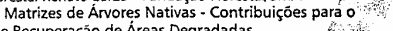

setor de Recuperasăo de Areas Degradadas.

16:00 - 16:45 Debate - Cooperaçáa téćnica e parcerias entre os agentes do setor de RAD.

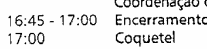


APÊNDICE 3 - Folder do Projeto Matrizes de Árvores Nativas - Frente.

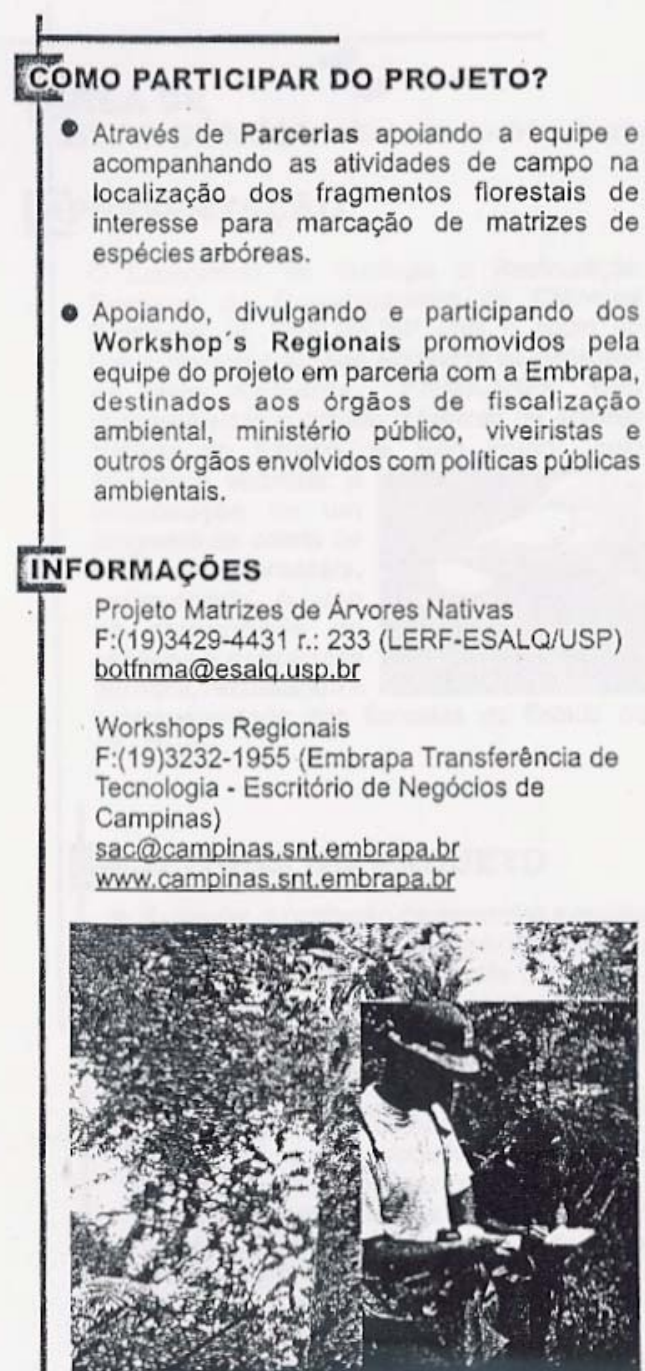

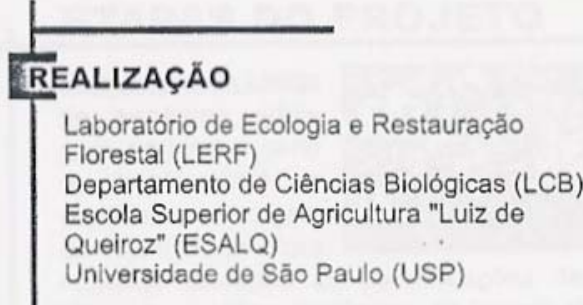

\section{TEARCERIA}

Embrapa Transferência de Tecnologia . Escritório de Negócios de Campinas Ministério da Agricultura, Pecuária e Abastecimento

Coordenadoria de Informaçōes Técnicas, Pesquisa Ambiental (CINP) Secretaria Estadual do Meio Ambiente (SMA)

\section{FINANCIAMENTO}

Fundo Nacional do Meio Ambiente (FNMA) Ministério do Meio Ambiente (MMA)
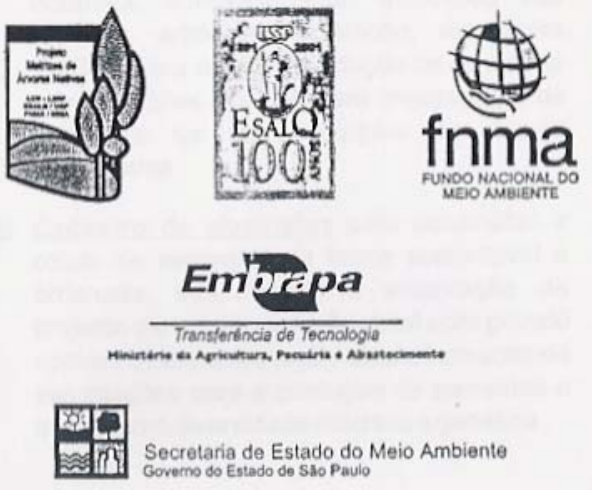

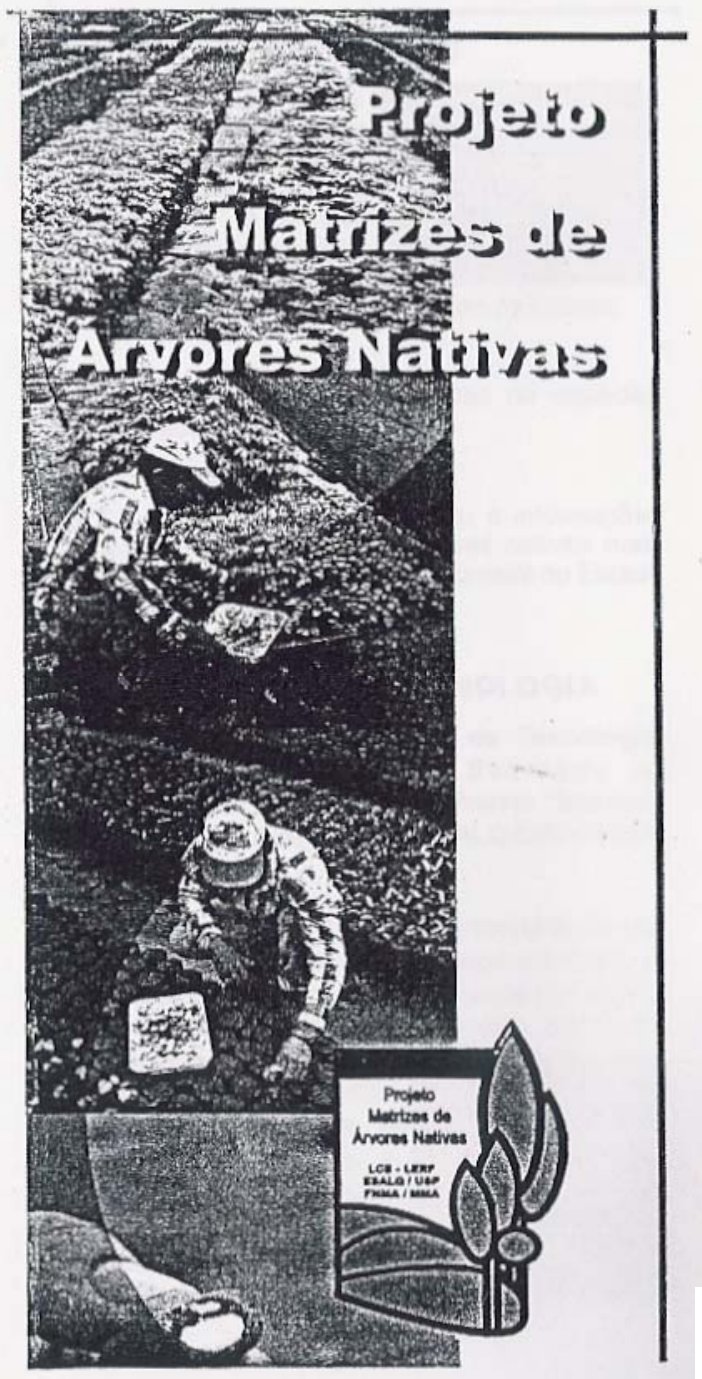


APÊNDICE 4 - Folder do projẹto Matrizes de Árvores Nativas - Verso.

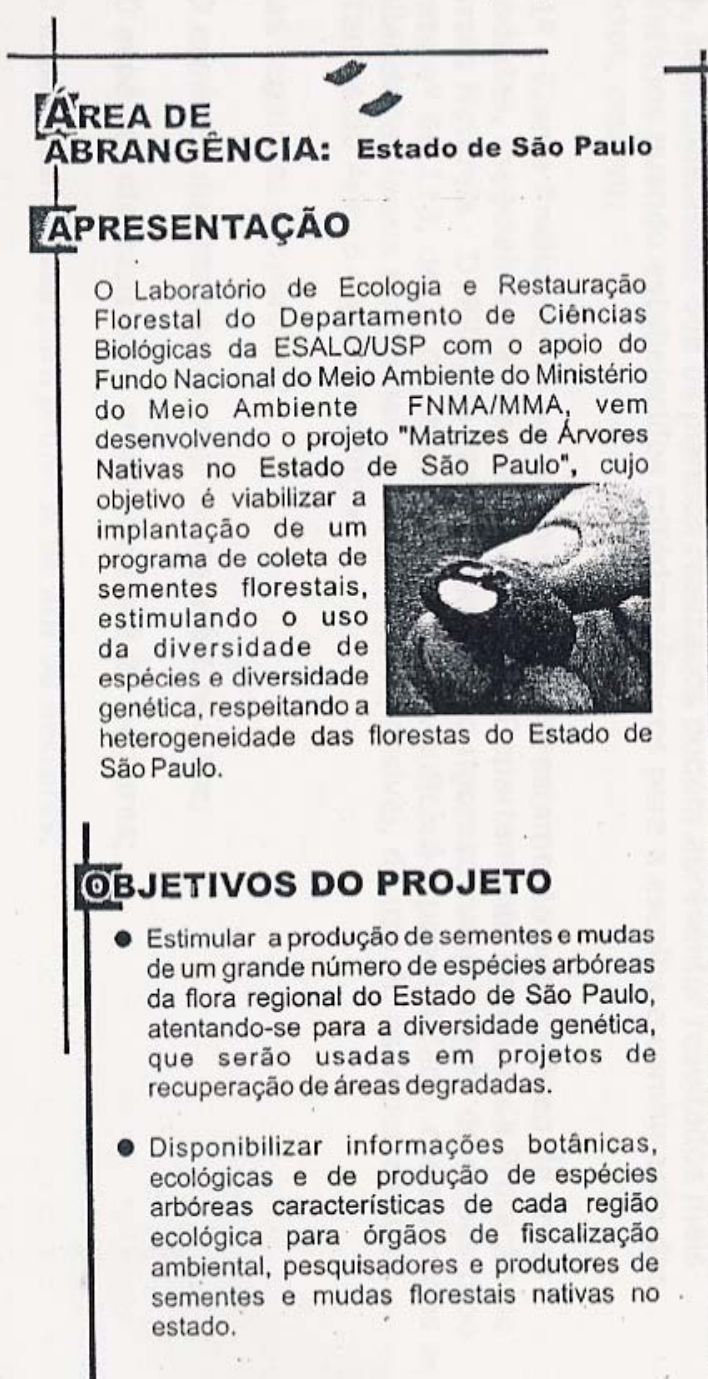

ETAPAS DO PROJETO

- Elaboração de Listas

de espécies arbóreas nativas a parti do levantamento de espécies e checagem de campo da. flora diferentes regiōes ecológicas do Estado de São Paulo (Mata Atlântica, Restinga, Floresta Seca, Floresta Paludosa, Mata Ciliar. Cerradão, etc.):

- Marcaçāo de Matrizes para coleta de sementes, localizadas e georeferenciadas em remanescentes florestais de propriedades particulares e unidades de conservação mais representativas de cada regiăo do Estado de SãoPaulo:

- Banco de dados contendo grande quantidade de informaçóes sobre as espécies arbóreas. O banco de dados será disponibilizado na Internet para consultas sobre eventuais dúvidas de identificação botânica, comportamento ecológico das espécies arbóreas, legislaçăo, exigências técnicas para coleta e produção de sementes e informaçōes básicas para implantaçăo de projetos de recuperação de áreas degradadas.

- Cadastro de viveiristas para possibilitar a coleta de sementes de forma sustentável ordenada, incentivando a elaboração de projetos de recuperação florestal com grande número de espécies regionais e a formaçăo de associaçōes para a produção de sementes mudas com diversidade florística e genética .

\section{1 \\ RESULTADOS ESPERADOS \\ - 12 trilhas para coleta de sementes, em seis regiōes,com apro- ximadamente $100 \mathrm{a} 120$ espécies arbóreas mais representativas \\ repra trilha \\ totalizando cerca de 800 espécies no Estado; \\ - 15.000 matrizes demonstrativas de espécies arbóreas marcadas no campo: \\ - Site na Internet com ilustração e informaçōes técnicas das espécies florestais nativas mais representativas de cada tipo florestal do Estado de São Paulo.}

\section{TTRANSFERENNCIA DE TECNOLOGIA}

A Embrapa Transferência de Tecnologia, representada pelo seu Escritório de Campinas/SP, é parceira do Projeto "Matrizes de Árvores Nativas" da ESALQ-USP/FNMAMMA.

A Embrapa contribui para a transferência das tecnologias geradas sobre as espécies florestais através da capacitação técnica junto aos órgãos de producăo e de fiscalização ambiental, buscando melhorar a qualidade das sementes e mudas regionais a serem produzidas $\theta$ ofertadas para implantaçăo de projetos de recuperação de áreas degradadas.

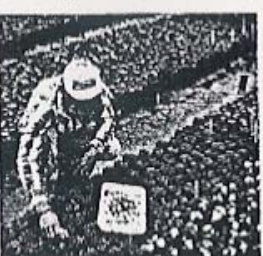


APÊNDICE 5 - Resolução SMA - 21, de 21-11-2001.

“Fixa orientação para o reflorestamento heterogêneo de áreas degradadas e dá providências correlatas".

O Secretário de Estado do Meio Ambiente, em cumprimento ao disposto nos artigos 23, VII, e 225, § 1이, I, da Constituição Federal, nos artigos 191 e 193 da Constituição do Estado, nos

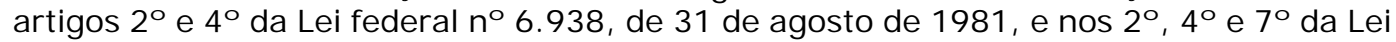
estadual no 9.509, de 20 de março de 1997, e

Considerando o "Projeto de Produção de Mudas de Plantas Nativas - Espécies Arbóreas para Recomposição Vegetal, de interesse para a economia estadual", aprovado pelo Decreto no 46.113, de 21 de setembro de 2001;

Considerando a constatação feita pela Coordenadoria de Informações Técnicas, Documentação e Pesquisa Ambiental - CINP, da Pasta, quanto à baixa diversidade vegetal das áreas reflorestadas com espécies nativas, nas quais têm sido utilizadas menos de 33 espécies arbóreas, o que se agrava, ainda mais, quando se verifica que são plantadas praticamente as mesmas espécies em todo o Estado, independentemente da região, sendo 2/3 (dois terços) delas iniciais da sucessão, de ciclo de vida curto (15-20 anos), o que irá levar os reflorestamentos ao declínio em um certo espaço de tempo, como vem sendo observado na prática;

Considerando que a perda da diversidade biológica significa a redução de recursos genéticos úteis e disponíveis ao desenvolvimento sustentável, na forma de madeira, frutos, forragem, plantas ornamentais e produtos de interesse alimentar, industrial e farmacológico;

Considerando que o Departamento Estadual de Proteção de Recursos Naturais - DEPRN, da Pasta, tem constatado que os plantios realizados podem apresentar resultados mais satisfatórios quando estabelecidos critérios técnicos para a escolha e combinação das espécies, resolve:

Art. 1으 - Com a finalidade de ser promovido o reflorestamento heterogêneo de áreas degradadas, especialmente nas matas ciliares, o Departamento Estadual de Proteção de Recursos Naturais - DEPRN, da Pasta, observado o rigoroso cumprimento do disposto no Decreto no 46.113, de 21 de setembro de 2001, verificará a possibilidade, consideradas as peculiaridades locais e regionais e tanto quanto possível, do uso de espécies nativas, constantes do Anexo a esta resolução:

I - nas seguintes proporções:

a) 30 espécies distintas para projetos de até 1 hectare;

b) 50 espécies distintas para projetos de até 20 hectares;

c) 60 espécies distintas para projetos de até 50 hectares;

d) 80 espécies distintas para projetos com mais de 50 hectares.

Diário Oficial do Estado de São Paulo - Meio Ambiente

Volume 111 - Número 221 - São Paulo, Sexta-feira, 23 de novembro de 2001. 


\section{APÊNDICE 5 - Resolução SMA - 21, de 21-11-2001.}

II - sendo priorizada a utilização de espécies ameaçadas de extinção, respeitando-se as regiões ou formações de ocorrência, na seguinte proporção:

a) $5 \%$ (cinco por cento) das mudas, com pelo menos 5 espécies distintas, para projetos de até 1 hectare;

b) $10 \%$ (dez por cento) das mudas, com pelo menos 10 espécies distintas, para projetos de até 20 hectares;

c) $10 \%$ (dez por cento) das mudas, com pelo menos 12 espécies distintas, para projetos de até 50 hectares;

d) $10 \%$ (dez por cento) das mudas, com pelo menos 15 espécies distintas para projetos com mais de 50 hectares.

$\S 1$ 으 - No caso de áreas degradadas localizadas em restingas, manguezais e florestas paludosas (mata de brejo):

I - as espécies selecionadas para o plantio serão escolhidas entre espécies arbóreas de áreas naturais da vizinhança, atentando para as variações edáficas e topográficas locais;

II - proporção de 50\% (cinqüenta por cento), sempre que possível, das espécies naturais existentes na vizinhança.

$\S 2$ ㅇ - As mudas a ser utilizadas deverão, preferencialmente, ser produzidas com sementes procedentes da mesma região da área objeto da recuperação e nativas do bioma ou formação florestal correspondente, bem como ter pelo menos $20 \mathrm{~cm}$ (vinte centímetros) de altura e apresentar sistema radicular e rustificação que possibilitem a sua sobrevivência pós-plantio.

§ 3o - Para a implantação das medidas de recuperação deverá ser utilizado o processo sucessional como estratégia básica.

Art. 2 o - Na execução dos trabalhos de recuperação deverão ser considerados o preparo do solo, as estratégias e técnicas de plantio e, especialmente, a distribuição das mudas das diferentes espécies no campo, além da possibilidade de auto-recuperação dessas áreas no que se refere à possibilidade da presença ou chegada de propágulos (sementes ou indivíduos remanescentes) oriundos do banco de sementes e da "chuva" de sementes, dependendo do local da área objeto de recuperação e da vizinhança, devendo, ainda, levar em conta a presença de remanescentes florestais próximos e considerar o histórico e uso atual da área, no que se refere às práticas culturais, com alteração da drenagem do solo, retirada ou revolvimento periódico do solo, uso de herbicidas e outros.

$\S 1$ 으 - As áreas reflorestadas deverão ser conservadas mediante o controle de formigas, realização de, no mínimo, 3 (três) capinas e/ou coroamento anuais, mantendo as entrelinhas vegetadas e baixas e, se possível, efetuar, pelo menos, duas adubações anuais com formulação normalmente utilizadas na região, ou de acordo com os resultados da análise do solo. 


\section{APÊNDICE 5 - Resolução SMA - 21, de 21-11-2001.}

$\S 2$ ㅇ - Nas restingas, manguezais e florestas paludosas (mata de brejo), deverá ser promovida a restauração da hidrodinâmica do solo e, no caso de áreas com retirada ou revolvimento anterior do solo, da sua estrutura.

Art. 3o - A Secretaria do Meio Ambiente, mediante programas específicos, estimulará o desenvolvimento de pesquisas para o aprimoramento do conhecimento científico das medidas estabelecidas nesta resolução, visando ampliar os conhecimentos sobre ecologia das espécies e formações e sobre tecnologia de produção de sementes e mudas, bem como estabelecer modelos alternativos para a recuperação de áreas degradadas, em conjunto com outras Secretaria de Estado, Universidades, instituições científicas, Poderes Públicos das demais esferas de governo e organizações não governamentais.

Artigo 40 - Esta resolução entra em vigor na data de sua publicação. Publicado novamente por ter saído com incorreções no D.O. de 22-11-2001.

ANEXO à Resolução SMA - 21, de 21-11-2001

Listagem das espécies arbóreas, com aindicação do bioma/ecossistema de ocorrência natural no Estado de São Paulo e a classe sucessional a que pertencem. Biomas/ecossistemas: $\mathrm{R}=$ Vegetação de Restinga, $\mathrm{MA}=$ Floresta Ombrófila Densa, $\mathrm{MM}=$ Floresta Estacional

Semidecidual, $\mathrm{MC}=$ Mata Ciliar, $\mathrm{MB}=$ Mata de brejo, $\mathrm{C}=$ Cerrado, FOM = Floresta Ombrófila Mista. Em negrito indica a ampla ocorrência da espécie no bioma/ecossistema correspondente. Classe sucessional: $\mathrm{P}=$ espécie pioneira ou secundária inicial, NP = Espécie secundária tardia ou clímax.

FAMÍ LI A/ESPÉCIE NOME POPULAR BIOMA/ECOSSISTEMA DE OCORRÊNCIA CLASSE/SUCESS

ANACARDIACEAE Astronium graveolens Guaritá MM/MC NP

Lithraea molleoides Aroeira-brava MM/MC/C P

Myracrodruon urundeuva (Astronium urundeuva) Aroeira-preta MM NP

Schinus terebinthifolius Aroeira-mansa R/MA/MM/MC/MB/C P

Tapirira guianensis Peito-de-pomba $R / M A / M M / M C / M B / C P$

ANNONACEAE/Annona cacans Araticum MM/MC/MB/P

Annona glabra Araticum-do-brejo R/MA/MM P

Duguetia lanceolata Pindaíva MA/MM/MC/MB NP

Rolliniamucosa Biribá MA NP

Rollinia sylvatica Cortiça-amarela MM/MC/MB NP

Xylopia brasiliensis Pau-de-mastro R/MA/MM/MC NP

APOCYNACEAE/Aspidosperma cylindrocarpon Peroba-poca MM/MC/MB NP

Aspidosperma parvifolium (Aspidosperma olivaceum) Guatambu R/MA/MM NP

Aspidosperma polyneuron Peroba-rosa MM/MC/MB NP

Aspidosperma ramiflorum Guatambu MM/MC NP

Aspidosperma tomentosum (Aspidosperma subincanum) Guatambu-vermelho MM NP

Peschiera fuchsiaefolia Leiteiro MA/MC/C P

Rauwolfia sellowii Casca-d'anta MM P

AQUIFOLI ACEAE/I lex paraguariensis Erva-mate MA/MM/MC/C/FOM NP

ARALI ACEAE/Dendropanax cuneatum Maria-mole MA/MM/MC/MB/C NP Didymopanax morototonii Mandioqueiro MM/MC NP 
APÊNDICE 5 - Resolução SMA - 21, de 21-11-2001.

Sciadodendron excelsum Carobão MM NP

ARAUCAURI ACEAE/Araucaria angustifolia Pinheiro-do-paraná FOM NP

ARECACEAE/Acrocomia aculeata (Acrocomia sclerocarpa) Macaúba MM/MC NP

Euterpe edulis Palmito-juçara R/MA/MM/MC/MB NP

Syagrus oleracea Gueroba MM/MC NP

Syagrus romanzoffiana Jerivá $R / M A / M M / M C / M B / C P$

ASTERACEAE/Gochnatia polymorpha Cambará MM/MC/MB/C/FOM P

Vernonia polyanthes Cambará-guaçu MM/MC $P$

BIGNONI ACEAE/Cybistax antisyphilitica I pê-verde R/C P

Jacaranda macrantha Caroba R/MA/MM P

Jacaranda micrantha Caroba-miúda MM/MC P

J acaranda puberula (J acaranda semisserrata) Carobinha R/MA/FOM P

Tabebuia alba I pê-amarelo-da-serra MA/MM NP

Tabebuia caraiba I pê-amarelo-do-serrado C NP

Tabebuia chrysotricha Ipê-amarelo-cascudo MA/MM/MB NP

Tabebuia heptaphylla I pê-roxo -sete-folhas MA NP

Tabebuia impetiginosa I pê-roxo-de-bola MA/MM/C/FOM NP

Tabebuia ochracea I pê-amarelo-do-campo MM/C NP

Tabebuia roseo-alba I pê-branco MM NP Tabebuia serratifolia I pê-amarelo MA/MM NP

Tabebuia umbellata I pê-amarelo-do-brejo R/MA/MM/MB NP

Tabebuia vellosoi I pê-amarelo-de-casca-lisa MA/MM NP

Zeyheria tuberculosa I pê-felpudo MM/MC P

BOMBACACEAE/Chorisia speciosa Paineira MM/MC/MB P

Eriotheca candolleana Embiruçu-do-litoral MA/MM/MC $P$

Eriothecagracilipes Paineira-do-campo C P

Eriotheca pentaphylla Sapopemba R/MA P

Pseudobombax grandiflorum Embiruçu-da-mata R/MA/MM/MC/MB P

Pseudobombax longiflorum Embiruçu-do-serrado $C$

PBORAGI NACEAE/Cordia ecalyculata Café-de-bugre MA/MM/MC/C/FOM P

Cordia sellowiana Chá-de-bugre R/MA/MM/MC/C $P$

Cordia superba Babosa-branca MA/MM/MC $P$

Cordia trichotoma Louro-pardo MA/MM/MC NP

Patagonula americana Guaiuvira MM/MC P

BURSERACEAE/Protium heptaphyllum Almecega MA/MM/MC/MB/C NP

Protium spruceanum Almecega MM NP

CARI CACEAE/J acaratia spinosa (Jacaratia dodecaphylla) J acaratiá MM/MC P

CARYOCARACEAE/Caryocar brasiliense Pequi C P

CECROPI ACEAE/Cecropia hololeuca Embaúba-vermelha MM P

Cecropia pachystachya Embaúba-branca R/MA/MM/MC/MB P

CELASTRACEAE/Maytenus ilicifolia Espinheira-santa MA/MM NP

CLUSIACEAE/Calophyllum brasiliense Guanandi R/MA/MM/MC/C NP

Garcinia gardneriana (Rheedia gardneriana) Bacupari R/MA/MM NP

Kielmeyera variabilis Pau-santo C NP

Diário Oficial do Estado de São Paulo - Meio Ambiente

Volume 111 - Número 221 - São Paulo, Sexta-feira, 23 de novembro de 2001. 
APÊNDICE 5 - Resolução SMA - 21, de 21-11-2001.

COMBRETACEAE/Terminalia argentea Capitão-do-cerrado MM/MC/C NP

Terminalia brasiliensis Cerne-amarelo MA/MM/MC/MB NP

Terminalia triflora Capitãozinho MA/MM/MC/MB NP

CUNONI ACEAE/Lamanonia ternata Guaperê R/MA/MM/C NP

EBENACEAE/Diospyros inconstans Marmelinho MM NP

ERYTHROXYLACEAE/Erythroxylum tortuosum Mercurinho C NP

EUPHORBI ACEAE/Alchornea glandulosa (Alchornea iricurana) Tanheiro R/MA/MM/MC/MB P

Croton floribundus Capixingui MA/MM/MC/MB/C P

Croton urucurana Sangra -d'água MA/MM/MC $P$

Hyeronima alchorneoides Aracurana-da-serra R/MA/MM/MB P

Mabea brasiliensis Canudo-de-pito R/MA P

Mabea fistulifera Canudeiro MM/C P

Pera glabrata Tamanqueira $\mathrm{R} / \mathrm{MA} / \mathrm{MM} / \mathrm{MC} / \mathrm{MB} / \mathrm{C} \mathrm{P}$

Sapium glandulatum Pau-de-leite R/MA/MM/MC/MB/FOM $P$

Savia dictyocarpa (Securinega guaraiuva) Guaraiúva MA/MM/MC NP

FLACOURTI ACEAE/Casearia gossypiosperma Espeteiro MA/MM/MC NP

Casearia sylvestris Guaçatonga R/MA/MM/MC/MB/C P

LAURACEAE/Cryptocarya aschersoniana Canela-batalha MA/MM/MC/FOM NP

Nectandra megapotamica Canelinha MA/MM/MC NP

Ocotea corymbosa Canela -do-cerrado MA/MM/MC/MB/C NP

Ocotea odorifera (Ocotea pretiosa) Canela-sassafrás R/MA/MM/MC NP

Ocotea puberula Canela -guaicá R/MA/MM/MC/MB NP

Ocotea pulchella Canela-preta R/MA/MM/MC/C/FOM NP

Persea pyrifolia Abacateiro-do-mato R/MA/MM/MC/C/FOM NP

LECYTHIDACEAE/Cariniana estrellensis J equitibá-branco R/MA/MM/MC/MB NP

Cariniana legalis J equitibá-vermelho MM/MC NP

LEG. - CAESALPINIOIDEAE/Apuleia leiocarpa Grápia MM/MC NP

Bauhinia forficata Unha-de-vaca MM/MC P

Bauhinia holop hylla Pata - de-vaca-do-cerrado C P

Cassia ferruginea Cássia-fístula MA/MM/MC P

Copaifera langsdorffii Òleo-de-copaíba MA/MM/MC/MB/C NP

Dimorphandra mollis Faveiro-doce $C P$

Diptychandra aurantiaca Balsaminho C NP

Hymenaea courbaril J atobá MM/MC NP Peltophoru m dubium (Peltophorum vogelianum)

Canafístola MM/MC P

Pterogyne nitens Amendoim-do-campo MM P

Schizolobium parahyba Guapuruvu R/MA/MM/MC P

Sclerolobium denudatum Passuaré R/MA NP

Senna macranthera Fedegoso MA/MM P Senna multijuga Pau-cigarra R/MA/MM/MC P

Diário Oficial do Estado de São Paulo - Meio Ambiente

Volume 111 - Número 221 - São Paulo, Sexta-feira, 23 de novembro de 2001. 
APÊNDICE 5 - Resolução SMA - 21, de 21-11-2001.

LEG. - MIMOSOIDEAE/Abarema langsdorffii (Pithecellobium langsdorffii) Raposeira-branca MA/MM NP

Acacia polyphylla Espinho-de-maricá R/MA/MM/MC $P$

Albizia edwallii (Pithecellobium edwallii) MA/MC P

Albizia hasslerii Farinha-seca MM/MC P

Albizia polycephala Albizia MM/MC P

Anadenanthera colubrina Angico-branco MA/MM/MC P

Anadenanthera falcata Angico-do-cerrado MM/C P

Anadenanthera macrocarpa Angico-vermelho MM/MC $P$

Enterolobium contortisiliquum Orelha-de-negro $M M / M C P$

Inga edulis Ingá-de-metro R/MA/MM P

Inga laurina (Inga fagifolia) Ingá-mirim R/MA/MM/MC/MB NP

Inga marginata Ingá-feijão R/MA/MM/MC/MB P

Inga sessilis Ingá-ferradura R/MA/MM/C/FOM NP

Inga uruguensis Ingá-quatro-quinas $\mathrm{MM} / \mathrm{MC} P$

Mimosa bimucronata (Mimosa sepiaria) Maricá R/MA/MM/MC $P$

Mimosa scabrella Bracatinga MA/FOM P Parapiptadenia rigida (Anadenanthera rigida) Angico-

da-mata MM/MC P

Piptadenia gonoacantha Pau-jacaré R/MA/MM/MC/MB P

Pithecellobium incuriale Chico-píres MM/MC P

Stryphnodendron adstringens Barbatimão MM/C NP

LEG. - PAPI LI ONOIDEAE Andira anthelmia Garacuí R/MA/MM/MC/C NP

Bowdichia virgilioides Sucupira - preta C P

Centrolobium tomentosum Araribá R/MA/MM/MC $P$

Cyclolobium vecchi Louveira MM/MC NP

Dalbergia miscolobium Caviúna-do-cerrado C NP

Dalbergia variabilis Assapuva MC NP

Erythrina crista-galli Corticeira-do-banhado MM/MC P

Erythrina falcata Corticeira-da-serra MA/MM/MC/MB/FOM P

Erythrina speciosa Mulungu-do-litoral R/MA P

Erythrina verna Suinã MM P

Holocalyx balansae Alecrim-de-campinas MM/MC NP

Lonchocarpus campestris Embirinha MM P

Lonchocarpus guilleminianus Embira-de-sapo R/MA/MM/MC P

Lonchocarpus muehlbergianus Embira-de-sapo MA/MM/MC P

Luetzelburgia auriculata Guaiçara MM NP

Machaerium aculeatum Pau-de-angú MM/MC/MB P

Machaerium acutifolium Bico-de-pato MC/C NP

Machaerium nictitans J acarandá-bico-de-pato R/MA/MM/MC/MB P

Machaerium paraguariense Cateretê MM/MC NP

Machaerium scleroxylon Caviúna MA/MM/MC NP

Machaerium stipitatum Sapuva MA/MM/MC $P$

Machaerium villosum ( Machaerium lanatum) Jacarandá paulista MM/MC/C P

Myrocarpus frondosus Óleo-pardo MA/MM/MC NP

Myroxylon peruiferum (Myroxylon balsamum) Cabreúva-vermelha MA/MM/MC/MB NP

Ormosia arborea Olho-de-cabra R/MA/MM/MC/C NP

Platycyamus regnelli Pau-pereira MM/MC P

Diário Oficial do Estado de São Paulo - Meio Ambiente

Volume 111 - Número 221 - São Paulo, Sextafeira, 23 de novembro de 2001. 
APÊNDICE 5 - Resolução SMA - 21, de 21-11-2001.

Platypodium elegans Jacarandá-do-campo MM/MC/C NP

Poecilanthe parviflora Coração-de-negro MM NP

Pterocarpus rohrii Aldrago R/MA P Pterodon pubescens (Pterodon emarginatus) Faveiro MM/C NP

Vataira macrocarpa Angelim-do-cerrado C NP Zollernia glabra Mocitaíba R NP LYTHRACEAE

Lafoensia glyptocarpa Mirindiba-rosa MA P

Lafoensia pacari Dedaleiro $\mathrm{MM} / \mathrm{MC} / \mathrm{MB} / \mathrm{C} P$

MAGNOLIACEAE/Talauma ovata Pinha-do-brejo MA/MM/MC/MB NP

MALPI GHI ACEAE/Byrsonima verbascifolia Murici C $P$

MELASTOMATACEAE/Miconia candolleana Jacatirão MA/MM/MC P

Miconia ligustroides J acatirão-do-brejo MM/MC/MB/C $P$

Tibouchina mutabilis Manacá-da-serra R/MA/MM P

Tibouchina pulchra Manacá-da-serra R/MA P

MELI ACEAE/Cabralea canjerana Canjerana R/MA/MM/MC/MB NP

Cedrela fissilis Cedro-rosa MA/MM/MC/MB/FOM P

Cedrela odorata Cedro-do-brejo MA/MM/MB P

Guarea guidonia Ma rinheiro MA/MM/MC/MB P

MORACEAE/Chlorophora tinctoria (Maclura tinctoria) Taiúva MM/MC/MB P

Ficus guaranitica Figueira-branca MM/MC/MB P

Ficus insipida Figueira-do-brejo R/MA/MM/MB P

MYRISTICACEAE Virola bicuiba (Virola oleifera) Bicuíba R/MA/MM NP

MYRSINACEAE Rapanea ferruginea Capororoca R/MA/MM/MC/FOM P

Rapanea guianensis Capororoca R/MA/MM/MC/MB/C P

Rapanea umbellata Capororoca R/MA/MM/MC/MB/C/FOM P

MYRTACEAE/Blepharocalyx salicifolius Murta R/MA/MM/MC/MB/C/FOM NP

Calyptranthes clusiaefolia Araçarana MM/MC NP

Campomanesia guazumaefolia Sete -capotes MM/MC/FOM NP

Campomanesia neriiflora Guabiroba-branca R/MA/MM/MC NP

Campomanesia phaea Cambuçi R/MA NP

Campomanesia xanthocarpa Gabiroba R/MA/MM/MC NP

Eugenia brasiliensis Grumixama R/MA/MM/FOM NP

Eugenia florida Pitanga-preta MA/MM/MC/MB NP

Eugenia involucrata Cereja-do-rio-granda MA/MM/MC NP

Eugenia leitonii Araçá-piranga MA NP Eugenia pyriformis Uvaia MA/MM NP

Eugenia speciosa Laranjinha-do-mato R/MA/MM/MC/MB NP

Eugenia uniflora Pitanga MM/MC/FOM NP

Myrcia tomentosa Goiaba-brava MM/C/FOM NP

Myrcianthes pungens Guabiju MM/C NP

Myrciaria tenella Cambuí MM/MC NP

Plinia rivularis Cambucá-peixoto MM/MM NP Psidium cattleianum (Psidium littorale) Araçá-dapraia R/MA/MM P

NYCTAGINACEAE/Guapira noxia Guapira MM/C NP

Guapira opposita Flor-de-pérola R/MA/MM/MC/MB/C/FOM NP

PHYTOLACCACEAE/Gallesia integrifolia (Gallesia gorazema) Pau-d'alho MM/MC P

Diário Oficial do Estado de São Paulo - Meio Ambiente

Volume 111 - Número 221 - São Paulo, Sextafeira, 23 de novembro de 2001. 
APÊNDICE 5 - Resolução SMA - 21, de 21-11-2001.

Phytolacca dioica Cebolão MM P Seguieria langsdorffi Agulheiro MM P

RHAMNACEAE/Colubrina glandulosa (Colubrina rufa) Saguaragi MA/MM/MC NP Rhamnidium elaeocarpum Saguaragi-amarelo MM/MC P

ROSACEAE/Prunus myrtifolia (Prunus sellowii) Pessegueiro-bravo R/MA/MM/MC/MB/C/FOM P RUBIACEAE/Amaioua guianensis Marmelada R/MA/MM/MC/C NP

Genipa americana Genipapo MM/MC NP

Posoqueria acutifolia Laranja-de-macaco MA/MM NP

RUTACEAE/Balfourodendron riedellianum Pau-marfim MM/MC NP

Dictyoloma vandellianum Tingui-preto R/MM/FOM $P$

Esenbeckia grandiflora Guaxupita R/MA/MM/MC/MB NP

Esenbeckia leiocarpa Guarantã MM NP Galipea jasminiflora Grumixara MM/MC NP

Helietta apiculata Canela-de-veado MM/MC P

Zanthoxylum rhoifolium Mamica-de-cadela MA/MM/MC/C/FOM P

Zanthoxylum riedelianum Mamica-de-porca MA/MM/MC/MB/C P

SAPI NDACEAE/Allophylus edulis Chat-chal MA/MM/MC P

Cupania racemosa Caguantã MA/MM/C/FOM NP

Cupania vernalis Arco-de-peneira MA/MM/MC/C NP

Diatenopteryx sorbifolia Correeiro MM/MC P

SAPOTACEAE/Chrysophyllum gonocarpum Caxeta-amarela MA/MM/MC NP

Chrysophyllum ramiflorum Guacá MA NP

Pouteria caimito Abíu R/MA NP

Pouteria ramiflora Leiteiro - preto C NP

Pouteria torta Guapéva MA/MM/C NP

SOLANACEAE Acnistus arborescens Marianeira R/MA/MM P

Solanum granuloso-leprosum Gravitinga MM/MC P

STERCULIACEAE/Guazuma ulmifolia Mutambo MM/MC $P$

TILIACEAE/Heliocarpus americanus J angada-brava MM/MC $P$

Luehea divaricata Açoita-cavalo-miúdo MM/MC/MB/C P

Luehea grandiflora Açoita -cavalo MM/MC/C P

ULMACEAE/Trema micrantha Crindeúva R/MA/MM/MC $P$

VERBENACEAE/Aegiphila sellowiana Tamanqueiro R/MA/MM/MC/MB P

Aloysia virgata Cambará-de-lixa MM P

Cytharexyllum myrianthum Pau-viola R/MA/MM/MB/C P

Vitex montevidensis (Vitex megapotamica) Tarumã MM/MC/MB/C NP

Vitex polygama Tarumã MA/MM/MC NP

VOCHYSI ACEAE Qualea dichotoma Pau-terra-mirim MM/MC/C NP

Qualea grandiflora Pau-terra C NP

Qualea jundiahy Pau-terra MM/MC NP

Vochysia bifalcata Pau-de-vinho R/MA/MM NP

Diário Oficial do Estado de São Paulo - Meio Ambiente

Volume 111 - Número 221 - São Paulo, Sextafeira, 23 de novembro de 2001. 